\title{
Potential for biofuel feedstock in Kenya
}

Geoffrey Ndegwa, Violet Moraa, Ramni Jamnadass, Jeremias Mowo, Meshack Nyabenge, Miyuki liyama 


\section{Potential for biofuel feedstock in Kenya}

Geoffrey Ndegwa, Violet Moraa, Ramni Jamnadass, Jeremias Mowo, Meshack Nyabenge, Miyuki liyama 


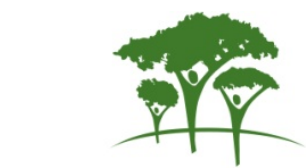

\section{LIMITED CIRCULATION}

World Agroforestry Centre

TRANSFORMING LIVES AND LANDSCAPES

Correct citation: Ndegwa G, Moraa V, Jamnadass R, Mowo J, Nyabenge M and Iiyama M. 2011. Potential for biofuel feedstock in Kenya. ICRAF Working Paper No. 139 Nairobi: World Agroforestry Centre. http://dx.doi.org/10.5716/WP11272.PDF.

Titles in the Working Paper Series aim to disseminate interim results on agroforestry research and practices and stimulate feedback from the scientific community. Other publication series from the World Agroforestry Centre include Technical Manuals, Occasional Papers and the Trees for Change series.

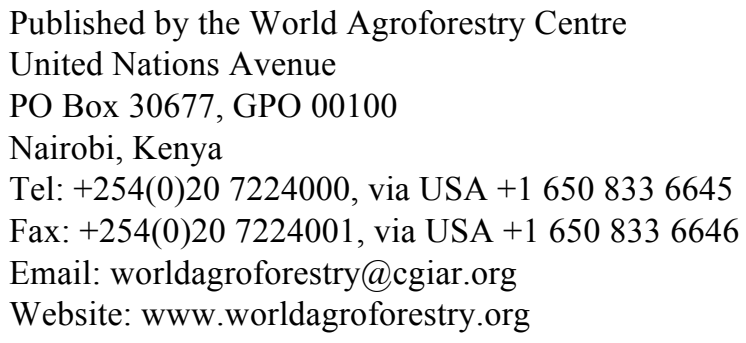

(C) World Agroforestry Centre 2011 Working Paper No. 139

The views expressed in this publication are those of the author(s) and not necessarily those of the World Agroforestry Centre.

Articles appearing in this publication may be quoted or reproduced without charge, provided the source is acknowledged. No use of this publication may be made for resale or other commercial purposes.

All images remain the sole property of their source and may not be used for any purpose without written permission from the source.

The geographic designation employed and the presentation of material in this publication do not imply the expression of an opinion whatsoever on the part of the World Agroforestry Centre concerning the legal status of any country, territory, city or area or its authorities, or concerning the delimitation of its frontiers or boundaries. 


\section{ABOUT THE AUTHORS}

Geoffrey Ndegwa is a Research Assistant at World Agroforestry Centre. He has an MSc in Renewable Energy Management (gefmaina@yahoo.com)

Violet Moraa is a graduate Research Fellow at the World Agroforestry Centre working in the East Africa Region. She has a Masters degree in Agricultural and Applied Economics from the University of Nairobi (v.moraa@,cgiar.org or violademorries@,gmail.com)

Dr Ramni Jamnadass, is the Global Research Priority Leader - Tree Genetic Resources and Domestication at the World Agroforestry Centre. She has a PhD in Molecular Genetics (r.jamnadass@cgiar.org)

Dr Jeremias Mowo is the Regional Coordinator, East Africa at the World Agroforestry Centre. He is a senior scientist and holds a PhD in Soil Science (j.mowo@cgiar.org)

Meshack Nyabenge is the GIS Coordinator at the World Agroforestry Centre. He has expertise in GIS, remote sensing, geodatabase, decision support systems, GPS and photogrammetry (m.nyabenge@,cgiar.org)

Dr. Miyuki Iiyama is a Socio-Economist, with special focus on natural resource management and bioenergy provision in agroforestry systems in East Africa (m.iiyama@cgiar.org) 


\section{ABSTRACT}

Many developing countries, Kenya included, want to diversify their domestic energy supply hence reduce dependence on highly volatile fossil fuel prices, enhance access to energy in rural areas, promote rural development and to reduce carbon emissions.

This study was done to assess the potential for supply of biofuel feedstock for bioethanol and biodiesel production for domestic consumption and export. To achieve this, key feedstocks were identified and their environmental suitability, production and yields analyzed. Gross margin as a tool was used to make an economic analysis of the production of the feedstocks compared to that of the most prominent food and cash crops. A review of the national biofuel strategies, policies and regulations currently adopted in Kenya was also done.

The study established that sweet sorghum and castor are the most environmentally suitable bioethanol and biodiesel feedstock respectively. In terms of gross margins, sweet sorghum has the highest gross margin at KSh 67,584 followed by sugarcane at KSh 37,746 and cassava at KSh 20,240 per hectare for bioethanol feedstocks. For biodiesel feedstocks, sunflower has the highest gross margin at KSh 2,921 per hectare.

It is expected that this study will play a significant role in guiding the policy makers in making important decisions to drive the biofuels sector forward.

Keywords: bioethanol, biodiesel, biofuel feedstocks, gross margins, Kenya 


\section{ACKNOWLEDGMENTS}

The study was funded by Overseas Development Institute (ODI) through the World Agroforestry Centre. The authors would therefore like to thank ODI for the financial support that made this study possible.

The authors would also like to acknowledge the valuable contributions of Dr Benard Muok (ACTS), Mrs Faith Odongo (MOE), Tabeel Nandokha (KARI), Dr Phanuel Oballa (KEFRI), Hannah Wanjiru (GAF), Fredrick Muyesu (KIRDI), Meshack Nyabenge (ICRAF GIS unit), Peter Maina (KESREF), Cosmas Ochieng (HSHC), Dileswar Pradhan (Bidco) and Patrick Shilisia (Mumias Sugar Comapany).

We are also grateful to the staff members of World Agroforestry Centre who played different but significant roles during this study. They include Georges Aertssen, Rose Onyango, Susan Yiapan, Nancy Oseko and Caroline Mbogo, among others.

Finally, to the farmers in Mumias and Kisumu who provided valuable information on sugarcane farming, the authors express their sincere gratitude. 


\section{TABLE OF CONTENTS}

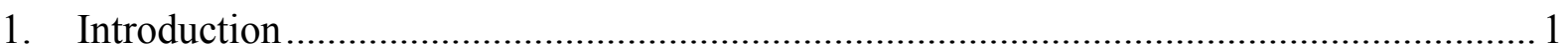

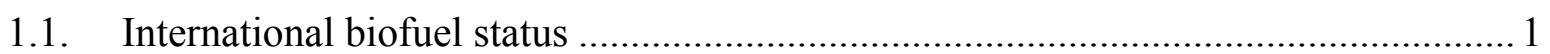

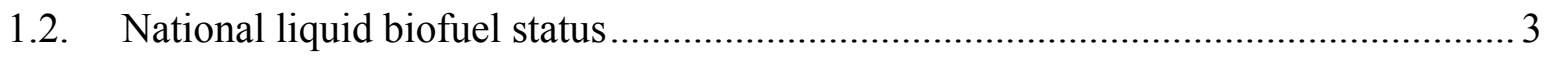

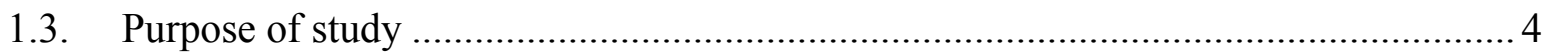

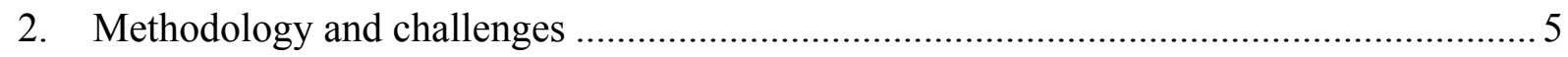

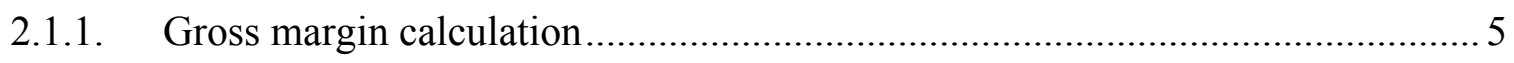

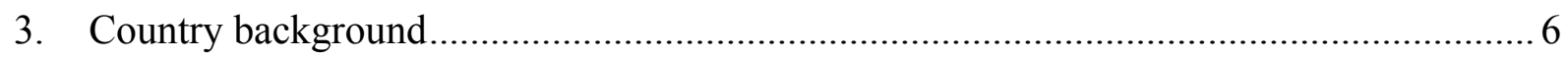

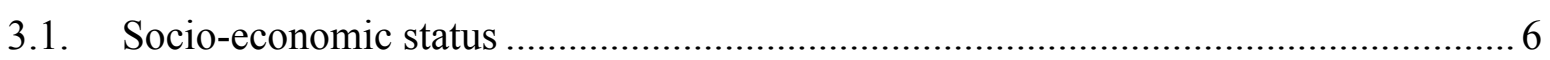

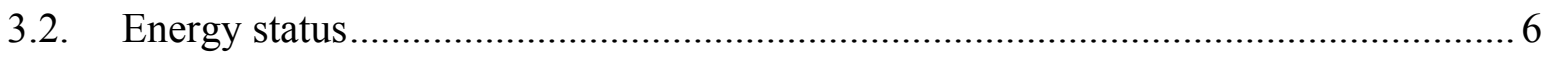

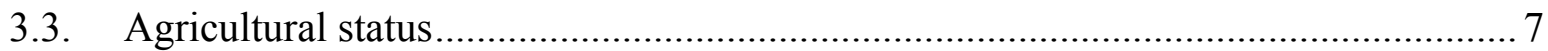

4. Potential supply of biofuel feedstock for domestic consumption and export .................. 10

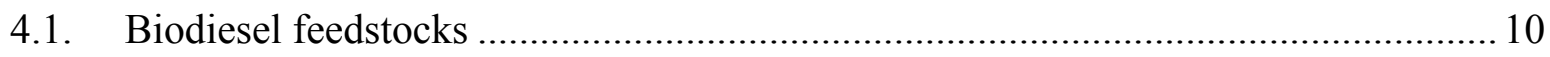

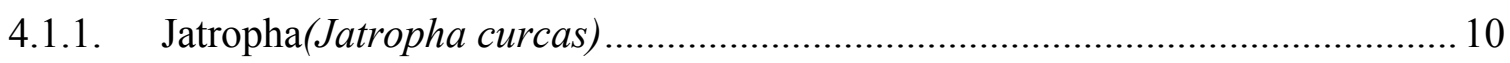

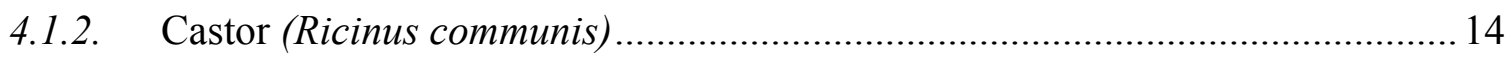

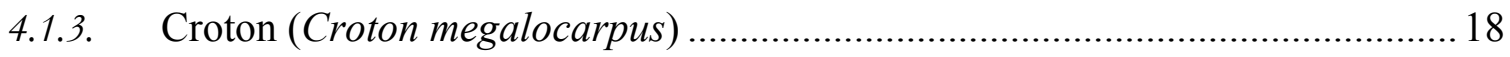

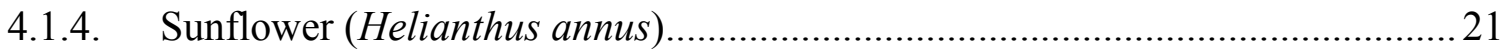

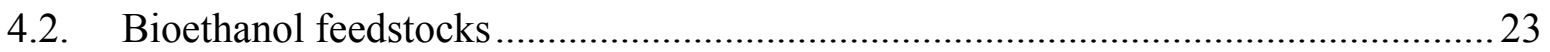

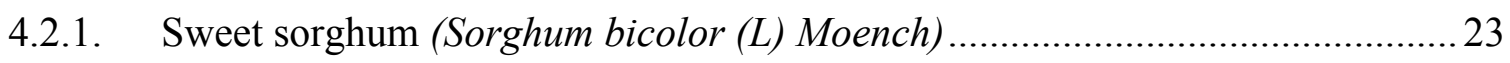

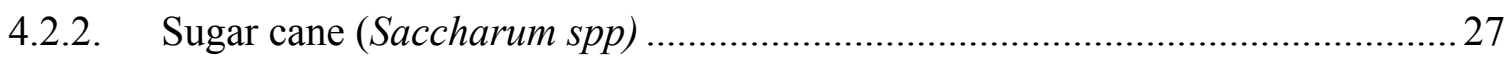

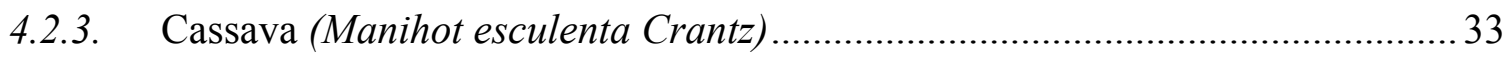

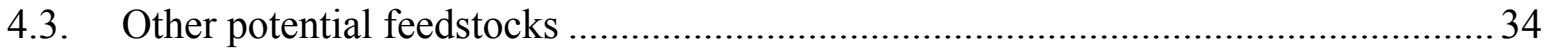

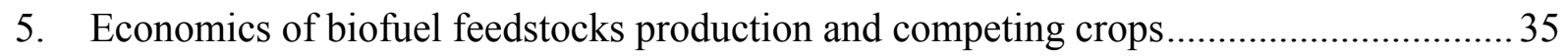

5.1. Gross margins of different feedstocks and competing crops .................................. 35

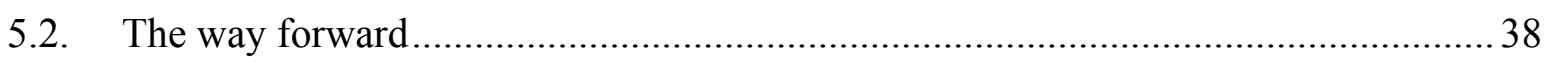

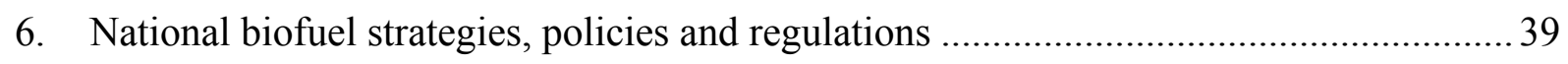

6.1. Existing national policies and legislations impacting on the biofuels sector ............39

6.2. Regional and international commitments impacting on biofuels. ............................ 41

7. Certification schemes and standards for biofuels or their feedstock ............................... 42

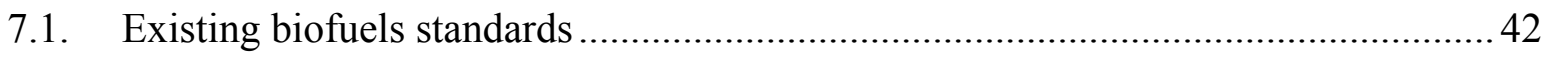

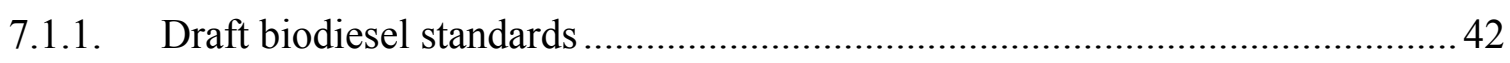

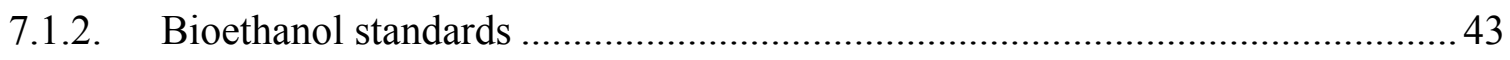




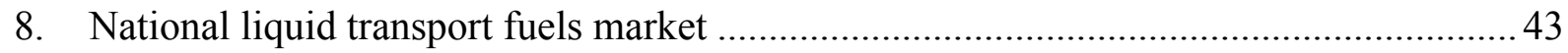

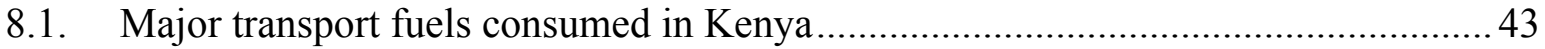

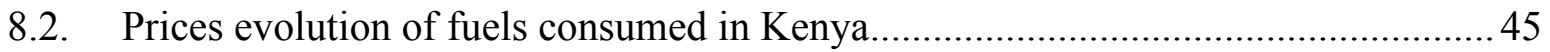

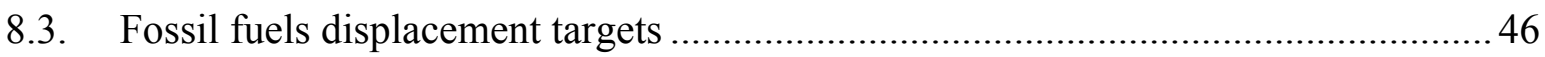

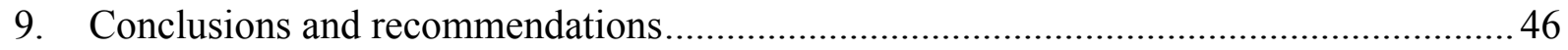

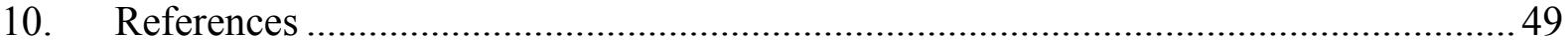

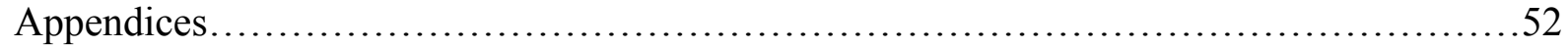

\section{List of figures}

Fig. 1: Development status of the main technologies to produce biofuels from biomass.......... 1

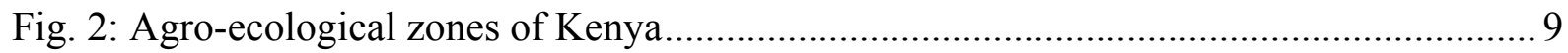

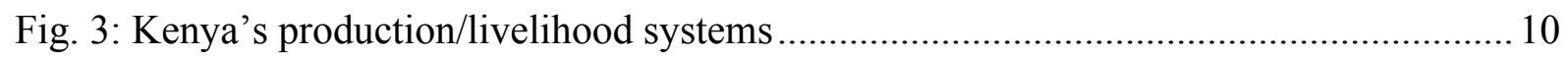

Fig. 4: Jatropha curcas at various stages of development in Kibwezi, Kenya....................... 11

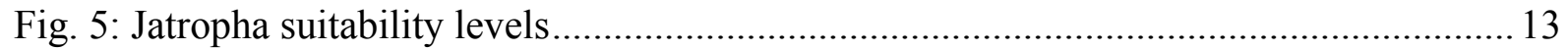

Fig. 6: Castor plant (left) and fruits (right) in Central province, Kenya. ............................... 15

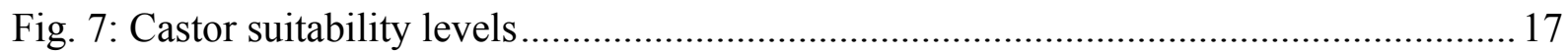

Fig. 8: Croton seedlings (left) and a fruiting croton tree (right) ........................................... 18

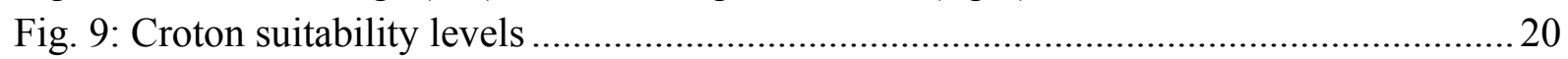

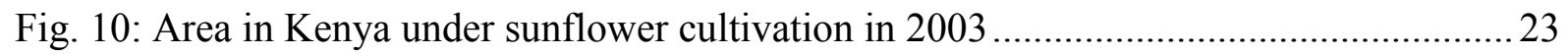

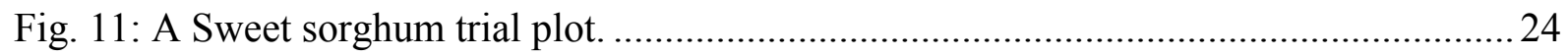

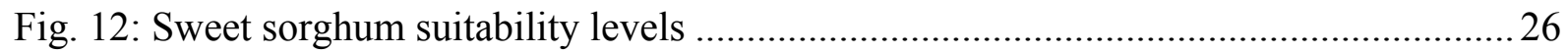

Fig. 13: Newly burned sugarcane ready for harvesting and newly harvested cane in Kibos... 28

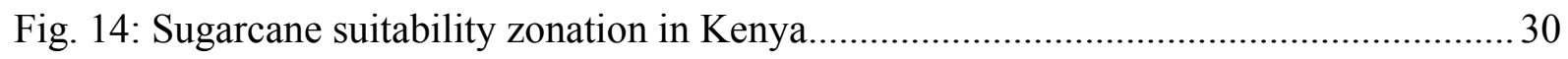

Fig. 15: Molasses storage tank and molasses transportation tank in Mumias sugar ................ 31

Fig. 16: MSC entrance and ongoing excavation at the proposed site for ethanol plant........... 33

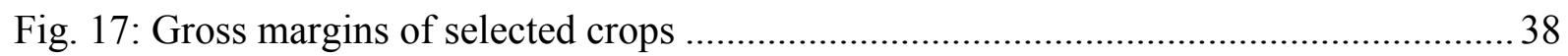

Fig. 18: Consumption of selected petroleum products ........................................................... 44

\section{List of tables}

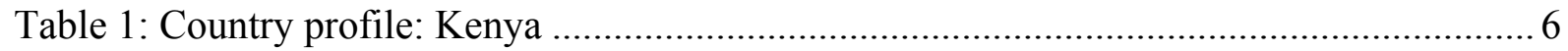

Table 2: Kenya's agro-ecological zone and agriculture potential ......................................... 8

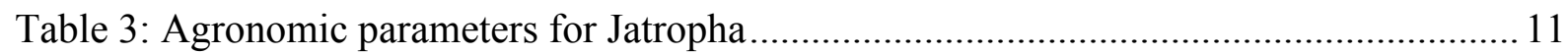

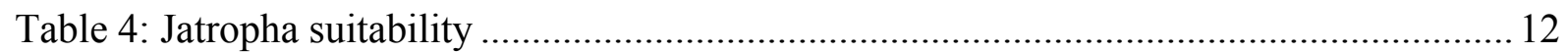

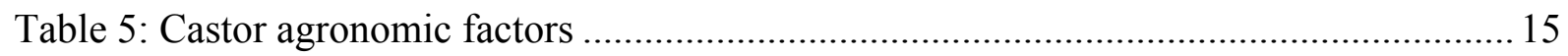

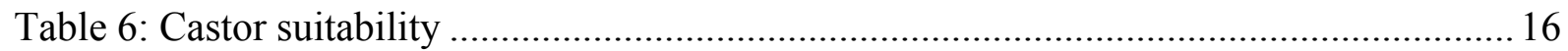

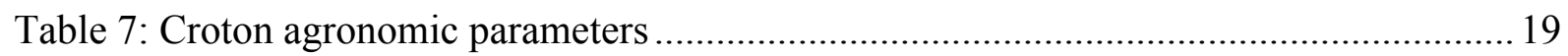

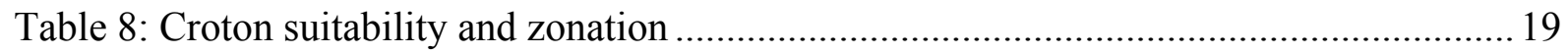

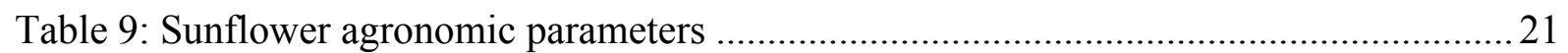

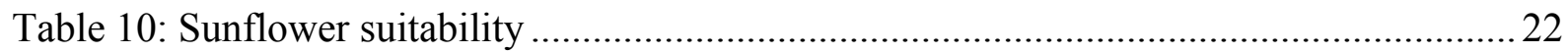

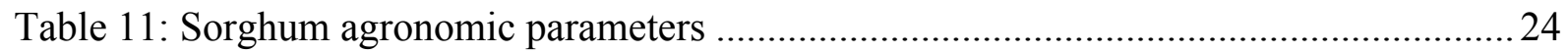




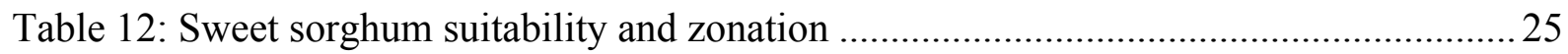

Table 13: National sorghum production 2005-2009 ….................................................... 27

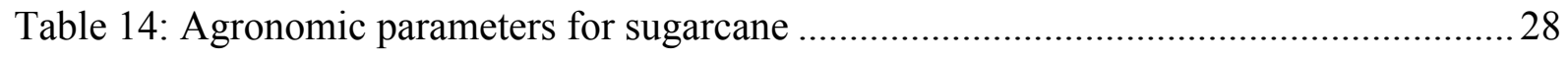

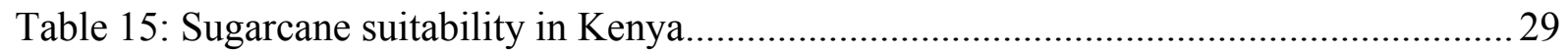

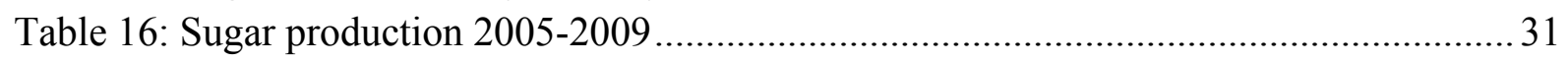

Table 17: Current sugar mills in Kenya and their crushing capacities.................................. 31

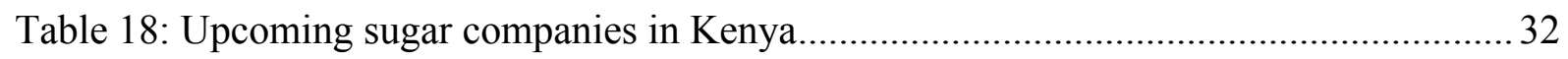

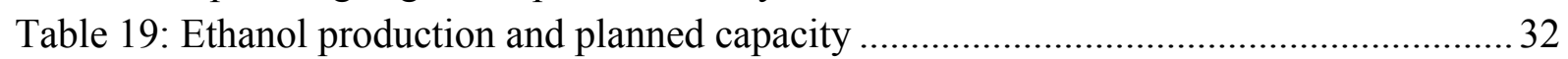

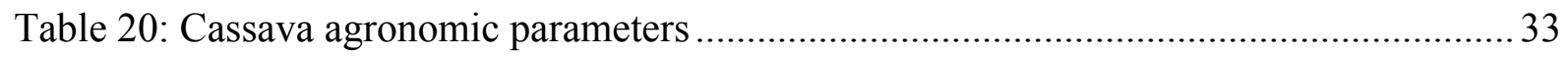

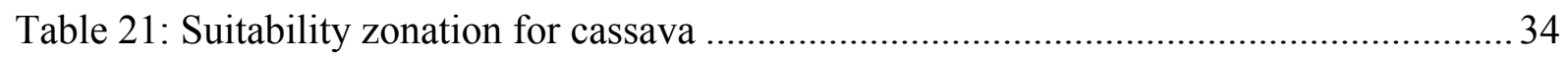

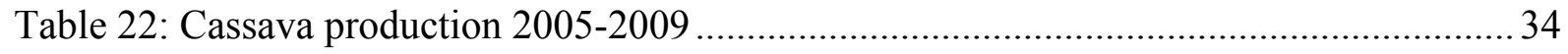

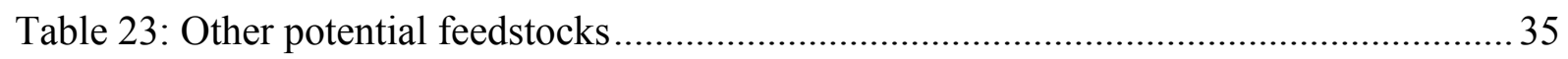

Table 24: Gross margins of selected crops in Kenya .......................................................... 37

Table 25: Land requirement to meet the E10 demand from sweet sorghum and sugarcane.... 39

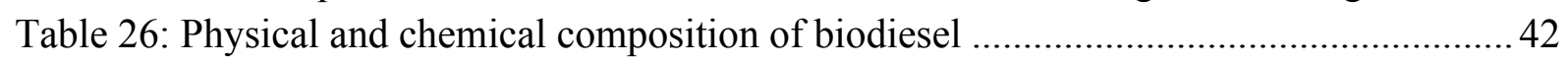

Table 27: Selected petroleum fuels consumption in Kenya from 2005-2009 ......................... 44

Table 28: Evolution of selected fuel prices in Kenya ....................................................... 45 


\section{ABBREVIATIONS AND ACRONYMS}

\begin{tabular}{|c|c|}
\hline $\mathrm{ACFC}$ & Agro Chemical and Food Corp \\
\hline ACTS & African Centre for Technology Studies \\
\hline ASALs & Arid and Semi Arid Lands \\
\hline $\mathrm{C} 3 \mathrm{P}$ & Crop Crisis Control Project \\
\hline CAN & Calcium ammonium nitrate \\
\hline CBD & Convention on Biological Diversity \\
\hline CBK & Central Bank of Kenya \\
\hline $\mathrm{CDM}$ & Clean Development Mechanisms \\
\hline CIA & Central Intelligence Agency \\
\hline COMESA & Common Market for Eastern and Southern Africa \\
\hline DAP & Diammonium phosphate \\
\hline DEG & Deutsche Investitions und Entwicklungsgesellschaft $\mathrm{GmbH}$ \\
\hline EIA & Environmental Impact Assessment \\
\hline EIAL & Environmental Impact Assessment License \\
\hline EMCA & Environmental Management and Coordination Act 1999 \\
\hline EPZA & Export Processing Zone Authority \\
\hline ERC & Energy Regulatory Commission \\
\hline ESDA & Energy for Sustainable Development Africa \\
\hline EU & European Union \\
\hline FAO & Food and Agriculture Organization of United Nations \\
\hline GAF & Green Africa Foundation \\
\hline GBEP & Global Bioenergy Partnership \\
\hline GDP & Gross Domestic Product \\
\hline GHG & Greenhouse Gases \\
\hline GIS & Geographical Information Systems \\
\hline GOK & Government of Kenya \\
\hline GTZ & German office for Technical Cooperation (currently GIZ) \\
\hline $\mathrm{Ha}$ & Hectares \\
\hline HSHC & Help Self Help Centre \\
\hline ICRAF & World Agroforestry Centre \\
\hline ICRISAT & International Crops Research Institute for the Semi-Arid Tropics \\
\hline IDRC & International Development Research Centre \\
\hline IEA & International Energy Agency \\
\hline IITA & International Institute of Tropical Agriculture \\
\hline IRR & Internal Rate of Return \\
\hline JKUAT & Jomo Kenyatta University of Agriculture and Technology \\
\hline JSP & Jatropha Support Programme \\
\hline KARI & Kenya Agricultural Research Institute \\
\hline $\mathrm{KCFC}$ & Kenya Chemical and Food Corp \\
\hline KEBS & Kenya Bureau of Standards \\
\hline KEFRI & Kenya Forestry Research Institute \\
\hline
\end{tabular}


KESREF Kenya Sugar Research Foundation

$\mathrm{kg} \quad$ Kilogramme

KIPPRA Kenya Institute for Public Policy Research and Analysis

KIRDI Kenya Industrial Research and Development Institute

$\mathrm{km} \quad$ Kilometre

KNBS Kenya National Bureau of Statistics

KOSF Kipevu Oil Storage Facility

KPC Kenya Pipeline Company

KPLC Kenya Power and Lighting Company

KPRL Kenya Petroleum Refineries Limited

KSB Kenya Sugar Board

KSh Kenya Shilling

MOA Ministry of Agriculture

MOE Ministry of Energy

mm millimetre

MW Megawatts

NEMA National Environment Management Authority

NGO Non-governmental Organization

NPV Net Present Value

OECD Organization for Economic Co-operation and Development

PISCES Policy Innovation Systems for Clean Energy Security

PPP GDP per capita

PV Photovoltaic

SVO Straight Vegetable Oil

TOFNET Trees on Farm Network

UNFCCC United Nations Framework Convention on Climate Change

US\$ United States Dollar

USA United States of America 


\section{INTRODUCTION}

Biofuels have gained significant importance in the past decade as the world struggles to address the problem of the ever increasing fossil fuel prices and global warming. As the world energy demand continues to grow in line with economic development and population growth, increases in the price of fossil fuels have put more pressure on the net importers. First generation liquid biofuels which include biodiesel, ethanol and straight vegetable oil (SVO) have been particularly promoted in many developed and developing countries which want to diversify their domestic energy supply, reduce dependence on highly volatile fossil fuel prices, enhance access to energy in rural areas, promote rural development and reduce carbon emissions.

At present, first generation liquid biofuels which comprise ethanol obtained from sugar and starch crops and biodiesel produced through transesterification of oil extracted from oil crops like oil palm and rape seed are the only commercially produced biofuels for the transport market. Second generation biofuels which include lignocellulosic ethanol and biodiesel from microalgae are at an advanced stage of research and are expected to play a major role in transport energy provision in future (IEA 2009).

First generation biofuels have the potential to play a major role in transport energy supply in many developing countries currently incurring huge fiscal burdens from imported fossil fuels. This is because the technology to produce them already exists and is easily adapted to suit existing local conditions (IEA 2009). These countries have vast land parcels currently underutilized, most of it considered marginal where many biofuel feedstocks can flourish. Prevalence of adequate labour (though mostly unskilled) in many of these rural areas means that the sector is guaranteed of receiving maximum support from poor communities who have few or no income generating opportunities. However, such an initiative has to be carefully pursued to ensure environmental protection and avoid conflict with indigenous communities since most of this perceived underutilized marginal land has a fragile ecosystem and is in most cases a source of pasture for the nomad communities.

\subsection{International biofuel status}

Biofuel production and demand has increased tremendously worldwide over the last years mostly as a result of support from respective governments especially in the developed countries. The sector is expected to experience continued growth until 2020, with most of it in USA and the European Union (Mitchell 2011). The International Energy Agency (IEA 2009) reported that in the year 2009, global biofuel production reached 83 billion litres contributing $1.5 \%$ of transport fuels. The EU has mandated that $10 \%$ of all transport fuels should come from biofuels by the year 2020. This means that by 2020 the total biofuels demand will be thrice the 15 billion litres that was consumed in 2009 in the transport sector. The United States of America (USA) has mandated that 136 billion litres of biofuels should be consumed by 2022 , almost triple the 45 billion litres consumed in 2009. The greatest consumption of biofuels in the USA is in the form of ethanol and the mandate for biodiesel is 3.8 billion litres.

While the mandate for biodiesel in EU is expected to be met locally, the mandate for ethanol is expected to benefit many African countries due to trade concessions that allow them dutyfree access. In 2008, emerging and developing countries accounted for $40 \%$ of the global biofuels production, with Brazil, China and Thailand being the highest producers outside the OECD countries (IEA 2009). Brazil is currently the largest developing country producer, having heavily promoted the production and use of ethanol since the 1970s. 
In Africa, Malawi has been producing ethanol since the 1970s, but on a much smaller scale, and currently several other African countries are producing it mostly for industrial purposes rather than fuel, and mainly from sugarcane (Mitchell 2011). Kenya was an exception having started production in 1977 . The country adopted ethanol blending in 1984. This was however abandoned in 1995 after the liberalization of the industry mostly due to unsustainable commercial arrangements as well as an inadequate policy framework (MOE 2010).

In the past few years, many foreign countries have seen great opportunities in some subSaharan Africa countries, such as Tanzania and Zambia, to acquire land to invest in largescale agrofuel plantations. These were generally aimed at export (ABN 2007) and not for local consumption, which is ironical bearing in mind that most of these countries are net importers of fossil fuels. Total ethanol production in Africa amounted to less than 500 million litres in 2006 with South Africa being the largest producer.

Ethanol production has the highest potential from sugarcane in Africa since cane growing is already taking place and the existing production technology is easily adapted to African conditions. In many countries, smallholder outgrowers are easily integrated into the system through subcontracting, thus ensuring they receive high quality inputs, technical field support, and an assured market. African ethanol exporters also have preferential access to the USA, but due to lower tariffs this is not expected to be their preferred target market.

Mitchell (2011) points out that large-scale biodiesel production for export is less attractive for African producers because production costs are expected to be higher than for southeast Asian producers and tariff advantages to the EU or USA markets are low hence do not offset the higher production costs. However with prices of fuel in sub-Saharan African countries almost double those in the most competitive markets, and landlocked countries facing even higher prices, demand for transport fuels is projected to grow by more than 5\% per year in subSaharan African countries between 2005 and 2020 which is expected to provide opportunities for domestic use.

Already, there are countries in tropical Africa with major development projects for jatropha biodiesel production. These include Mali, Burkina Faso, Ghana, Tanzania, Malawi, Zambia and Madagascar. Most of the jatropha is grown as a mono-crop in plantations, mixed cropping with other food crops and as hedges. The total length of jatropha hedges in tropical Africa is estimated at 75,000 km, yielding potentially 60,000 tonnes of seeds per year (Wiskerke 2008).

IEA (2010b) states that to achieve the ambitious bioenergy potential targets especially in Africa, government policies, and industrial efforts need to be directed at increasing biomass yield levels and modernizing agriculture to ensure increased food production in a continent faced with food insecurity. This can be achieved through technology development, and by the diffusion of best sustainable agricultural practices. To this end, several African countries have adopted pro-biofuel strategies that also promote food security. These include Malawi, Mali, Mauritius, Senegal, South Africa, Zambia and Zimbabwe (FAO 2007). However, some moves have been controversial, especially when foreign investors have acquired large tracts of land to invest in biofuel crops. A good example is in Madagascar where Daewoo Logistics of South Korea acquired 1.3 million hectares to farm maize and palm oil and in Tanzania where foreign countries grow sugarcane for ethanol production in their own countries (PISCES 2009). 


\subsection{National liquid biofuel status}

\section{Bioethanol}

Bioethanol is an alcohol-based fuel produced by fermentation of sugars in the presence of yeast to produce alcohol and carbon dioxide. It uses naturally occurring feedstocks like sugarcane, cassava, wheat, maize and sorghum. Most of these feedstocks are grown in Kenya but ethanol production has only been done from sugar molasses so far. Since ethanol is currently not used as a fuel, it is produced for industrial purposes like solvents, alcoholic beverages and for use in the production of pharmaceutical products (MOE 2009).

There are two main types of ethanol that are used as fuel: hydrous and anhydrous. Hydrous alcohol contains $4 \%$ water and can only be used in vehicles that are specifically designed for it. Anhydrous alcohol has almost no water and can be blended with gasoline and used in ordinary vehicles. Blends ranging from $10 \%$ ethanol and $90 \%$ gasoline (referred to as E10) to $85 \%$ ethanol and $15 \%$ gasoline have been used in various parts of the world (MOE/GTZ 2008).

Ethanol production for fuel in Kenya can be traced back to 1977 with the construction of the Kenya Chemical and Food Corp (KCFC) which was aimed at producing ethanol for blending, but this did not start until 1983 (MOE 2010). The blend was a substitute for premium gasoline (93 octane) with a volume composition of $65 \%$ super petrol, $10 \%$ alcohol and $25 \%$ ordinary or regular petrol. The programme which was experimental in Nairobi region included incentives such as Government tax relief, free provision and maintenance of ethanol storage, handling and blending facility for the oil marketers, priority access to molasses as raw material and restricted production of industrial and potable alcohol. In 1983, another power alcohol plant, Agro Chemical and Food Corp (ACFC) was constructed to support the national blending programme. Blending was however abandoned in 1995 after the liberalization of the industry mostly due to unsustainable commercial arrangements as well as an inadequate policy framework (MOE 2010). The handling, pricing and operational logistics made the bioethanol fuel venture commercially unattractive to both the biethanol producers and the petroleum marketers.

Currently, the government is trying to revive the ethanol-blending programme. This was expressed in a gazette notice no.12900 of November 24, 2009, which gave the blending guidelines and set the date of roll-out as March 2010 which was later postponed to September 2010. The notice stated that, "With effect from March 1 2010, all motor gasoline loaded from the petroleum storage and loading depots..., for sale in Kenya, shall be blended with power alcohol to make gasohol." Blending was expected to begin at the Kenya Pipeline Company depots in Kisumu, Eldoret and Nakuru because they are close to the sugar belt. However, the programme has not yet begun and Kenya Pipeline Company (KPC), the agency charged with blending the fuel at its storage reservoirs is yet to identify the suppliers of the ethanol and complete fixing the facilities where blending is to be done (Business Daily 2011).

\section{Biodiesel}

Biodiesel is a vegetable oil or animal fat-based diesel fuel consisting of long-chain alkyl esters made by chemically reacting with an alcohol in a process called transesterification. It can be derived from a variety of oil-bearing plants like castor, croton, jatropha, sunflower and coconut (MOE/GTZ 2008). It contains between $88-95 \%$ as much energy as diesel but has an advantage over diesel in that it improves the lubricity to the diesel and raises the cetane value. 
It also has a higher oxygen content which aids in the completion of fuel combustion hence reducing particulate air pollutants, carbon monoxide and hydrocarbons (MOE 2010).

Biodiesel can be blended with traditional diesel fuel or burned in its pure form in ordinary compression ignition engines. The blends can range from $1 \%$ biodiesel and $99 \%$ diesel (B1) to $25 \%$ biodiesel and $75 \%$ diesel (B25). However, the most common blends are B5 and B20. A research on biofuels done in Kenya commissioned by GTZ and the Ministry of Energy recommended a B2 blend as the most feasible and sustainable (MOE/GTZ 2008).

Compared to bioethanol, the biodiesel sector in Kenya is at its infant stage. Promotion of biodiesel has been mainly by NGOs and the private sector which had identified growth of feedstocks as a major source of income generation for the people living in marginal areas. Most of these organizations like Vanilla Jatropha Development Foundation and Green Africa Foundation promoted jatropha to farmers mostly in the arid and semi-arid areas due to the belief that it could perform well under harsh conditions and required minimum inputs and care. The seeds being inedible also ensured that the problem of competition with food does not arise (MOE/GTZ 2008). Though the most promoted feedstock has been jatropha, others like croton and castor have been given consideration (MOE 2010).

The growth of the sector has of late raised a lot of controversy with the farmers abandoning jatropha due to poor yields and lack of market for the produce. Many people have raised concern over how the crop was promoted without proper research on its agronomical requirements and seed germplasm. Lack of processing infrastructure and a policy and legal framework only made the situation worse since the farmers who harvested the seeds did not have the technical capacity to process them to oil and there was no established market (MOE/GTZ 2008; GTZ 2009a).

The government, which was seen as a late entrant in the scene, has been actively involved in trying to salvage the situation. This has been through commissioning of a study together with GTZ in 2008 titled, "A Roadmap for Biofuels in Kenya; Opportunities and Obstacles", facilitating drafting of the biofuel policy, biodiesel strategy and bioethanol strategy in the last three years. The Biodiesel Association of Kenya which comprises major stakeholders, like NGOs and research institutions in which the government is represented by its ministry officials was also formed in 2008 to promote and co-ordinate all activities related to biodiesel.

\subsection{Purpose of study}

The aim of this study is to assess the potential supply of biofuel feedstock for bioethanol and biodiesel production for domestic consumption and export in Kenya. To achieve this, key feedstocks were identified, and the land used for their production and yields analyzed.

Gross margin as a tool was used to come up with an economic analysis of the production of the feedstocks compared to that of the most prominent food and cash crops. The production methods used, the scale and type of production methods adopted were also considered. A review of the national biofuel strategies, policies and regulations currently adopted in Kenya was done. Since the success of the liquid biofuels sector will also depend on their quality and safety, a report on certification schemes and any standards that apply to biofuels or their feedstocks was compiled. It is expected that the biofuels will displace fossil fuels in the transport industry hence a review of the national liquid transport fuels market was done to estimate the amount of fuel consumed and the price development over 10 years. 


\section{METHODOLOGY AND CHALLENGES}

The major part of this study was conducted through literature review. Published reports, archival data and Internet resources were extensively reviewed. Among the reports that were heavily referred to include A Roadmap to Biofuels in Kenya; Opportunities and Obstacles, (MOE/GTZ 2008), Environmental Suitability and Agro-environmental Zoning of Kenya for Biofuel Production (Muok et al 2010) and Jatropha; A Reality Check (GTZ 2009). Semistructured interviews with stakeholders and key informants in the biofuels sector were conducted to get a deeper insight into the sector, as well as validate the data from the secondary sources.

A three-day site visit to Spectre International Limited, Mumias Sugar Company and Kenya Sugar Research Foundation (KESREF) yielded important information on the sugarcane and sugar production in the country. The trip also included a visit to three sugarcane farmers who gave a detailed account of their sugarcane farming and the challenges they face.

The main constraint faced during the study was time limit. This limited the geographical coverage of the interviews as well as the number of stakeholders who could be interviewed.

\subsection{Gross margin calculation}

Gross margin calculation as a tool is used mostly by farmers to help in choosing between different farming systems. It was selected to help evaluate the competitiveness of growing specific biofuel feedstocks compared to growing other food and cash crops. A gross margin of a crop is the difference between the gross income earned by the crop and the variable or direct costs associated with it (Abbott and Makeham 1979). The wages of permanent workers and depreciation of machinery is normally left out when calculating the gross margins.

\section{Gross margin $=$ Gross income - Variable costs}

\section{Where:}

Gross income is obtained by multiplying the gross output (yields) by the "farm-gate" price received for the product.

Variable costs are the costs directly linked to the crop or farm method. The more of a crop a farmer grows the more of these costs he will incur. They include cost of seeds, spray, ploughing, fertilizer, harvesting, packing marketing, storage, etc.

It is important to note that the gross margins should not be negative for any farming enterprise if the farmer is to make profits. Abbott and Makeham (1979) argue that for semi-subsistence farmers, food security might be more important than gross margins, but if one or two crops have very high gross margins, then it is advisable to grow them and buy food from the returns.

During the research, the cash flows were estimated using the current market prices of commodities. For perennial crops, an investment period of 10 years was considered and analyzed and resulting cash flows discounted at $14 \%$ interest rate which was the rate in the country at the time of writing this report (CBK 2011). The 10-year net present value (NPV) was then divided by 10 to get the annual NPV equivalent which was considered the annual gross margin. 


\section{COUNTRY BACKGROUND}

\subsection{Socio-economic status}

Kenya has a total land area of $569,250 \mathrm{~km}^{2}$ and an estimated population of 39 million inhabitants (2009 Population Census). Nairobi and its suburbs, the central highlands and the shores of Lake Victoria have the highest population density of more than 600 people per square kilometre (Harding and Devisscher 2009). The country has a GDP per capita (PPP) of US $\$ 1,600$ and about $50 \%$ of the population lives below the poverty line. The economically active population (comprising all persons aged 15 and above who supply labour for the production of goods and services during a specified time reference period) is projected to increase from 17,825 (80.9\%) in 2008 to 24,821 (81\%) in 2020.

Although Kenya's economic performance has exceeded that of most other African nations, its benefits have been seriously diluted by several factors. Some of these are poor governance and corruption, increasing economic inequality and environmental deterioration partly caused by high surging population and erratic weather patterns (KIPPRA 2010). The country's key economic sectors include agriculture, tourism, livestock/pastoralism, horticulture, fisheries, and forest products. In 2009, the agricultural sector contributed $22 \%$ to the country's GDP, industrial sector contributed 16\% and the service industries 62\% (CIA 2011).

The largest population lives in rural areas with the concentration largely dependent on the climatic and soil conditions. Highly productive agricultural areas in Central, Rift Valley and Western Provinces and major urban centres such as Nairobi, Mombasa and Nakuru have a high population density.

Table 1: Country profile: Kenya

\begin{tabular}{|l|l|}
\hline Area $\left(\mathbf{k m}^{\mathbf{2}}\right)$ & 580,367 \\
\hline Population & $39,802,015$ \\
\hline GDP per capita (PPP) - 2009 estimate (US\$) & 1,600 \\
\hline Contribution of agriculture to GDP (\%) & 22 \\
\hline Population employed in agricultural sector (\%) & 75 \\
\hline Population below poverty line-2008 estimate (\%) & 50 \\
\hline Main exports & $\begin{array}{l}\text { Coffee, tea, pyrethrum, horticultural } \\
\text { products, fish. }\end{array}$ \\
\hline
\end{tabular}

Source: Ndegwa, 2010

\subsection{Energy status}

The Government considers the energy sector a key enabler to achieving Vision 2030, a development blueprint that aims to transform Kenya into a newly industrializing, middleincome country providing a high quality life to all its citizens by the year 2030 (MOE 2010). Electricity and petroleum receives the highest government attention even though fuelwood is the most common fuel in Kenya (Ndegwa 2010). This is because petroleum and electricity are the most dominating fuels in the commercial sector hence are seen as the drivers to industrialization. Other major energy consumption sectors apart from the commercial sector, are transport, manufacturing and residential sectors.

The principal end energy supply sources in Kenya are biomass $68 \%$, petroleum $22 \%$, electricity $9 \%$ and coal at less than $1 \%$ (GOK 2008). The energy scene thus exhibits a 
predominant reliance on dwindling biomass energy resources to meet energy needs, especially for the rural households and a heavy dependence on imported petroleum to meet the modern economic sector needs. In the electricity sub-sector, hydropower accounts for $57 \%$ followed by fossil-based thermal generation which accounts for 33\% and geothermal $10 \%$. The other forms of renewable energy, including wind, solar, biogas and micro-hydro account for less than $1 \%$ (NEMA 2007).

Over $90 \%$ of rural households use firewood for cooking and heating while $80 \%$ of urban households depend on charcoal as a primary source of fuel for cooking (ESDA 2005). In 2006, biomass demand was estimated at 38.1 million tonnes against a sustainable supply of 15.4 million tonnes, creating a demand-supply deficit of 60\% (NEMA 2007). The demand is estimated to be growing at $2.7 \%$ per year while sustainable supply was growing at a slower rate of $0.6 \%$ per year (GOK 2002).

Electricity remains far beyond the poor majority as the cost remains high at US\$0.15 per $\mathrm{KWh}$ (Ogweno et al 2009). Access to electricity in the country stands at $83 \%$ of the population, but only $18 \%$ of the people are connected to the grid (GOK 2008). Connection is lowest in the rural areas where it stands at $4 \%$ while in the urban areas it stands at $51 \%$. Solar energy, which has gained a lot of importance in the rural areas to charge mobile phones and power electronics like radios and televisions, has been increasing quite fast. Currently, solar photovoltaic (PVs) provide $4 \mathrm{MW}$ of off-grid electricity, mainly to small household ruralbased consumers. Communities especially in the central region of the country are also engaged in micro-hydro power production where the resource is available (KIPPRA 2010).

\subsection{Agricultural status}

Land in Kenya is considered a basic commodity that supports life and is highly treasured. As much as $85 \%$ of the country landmass is classified as marginal and about $15 \%$ of land has medium to high potential. Population pressure has led to encroachment of the arid and semiarid lands (ASALs) which have a fragile ecosystem, a fact that may lead to further degradation (NEMA 2007).

The country has climatic and ecological extremes, with altitudes varying from sea level to over $5000 \mathrm{~m}$ in the highlands with most of the country having a tropical climate. It is hot and humid at the coast, temperate inland and very dry in the north and northeastern parts of the country (NEMA 2009). The average annual rainfall at the coast is $1200 \mathrm{~mm}$ and the average daily temperature ranges from $27^{\circ} \mathrm{C}-31^{\circ} \mathrm{C}$. Nairobi, the capital city, has an altitude of $1661 \mathrm{~m}$ and has a temperature range of $14^{\circ} \mathrm{C}-25^{\circ} \mathrm{C}$. Eldoret, sitting in the Rift Valley at an altitude of $3085 \mathrm{~m}$, has temperatures which range from $10^{\circ} \mathrm{C}-24^{\circ} \mathrm{C}$. Lodwar, also in the Rift Valley but near the northern-most extremity is at an altitude of $506 \mathrm{~m}$ above sea level, with a temperature range of $24^{\circ} \mathrm{C}-35^{\circ} \mathrm{C}$ (KIPPRA 2010).

There are two rainy seasons; the long rains occurring from April to June and short rains from October to December. The hottest period is from February to March and coldest is from July to August. The majority of the country receives less than adequate rainfall to support rain-fed crop cultivation. Over two-thirds of the country receives less than $500 \mathrm{~mm}$ of rainfall per year and $79 \%$ has less then $700 \mathrm{~mm}$ annually (KIPPRA 2010). Eleven per cent $(11 \%)$ of the country receives more than $1000 \mathrm{~mm}$ per year. The mean annual rainfall shows a wide spatial variation, ranging from about $200 \mathrm{~mm}$ in the driest areas in north-western and eastern parts of Kenya to the wetter areas with rainfall of 1200-2000 $\mathrm{mm}$ in areas bordering Lake Victoria and the Central Highlands east of the Rift Valley. As a result, the Central Highlands, parts of Rift 
Valley, the Lake Victoria region and the coastal area boast the most intensive agriculture and greatest concentration of people. Pastoral farming dominates the remaining drier regions of Kenya. The mean annual rainfall ranges from less than $250 \mathrm{~mm}$ in semi-arid and arid areas to more than $2000 \mathrm{~mm}$ in high potential areas.

The country has seven main agro-ecological zones. Zones I to III have humid to sub-humid climate and have the highest agricultural potential. Rain-fed agriculture, intensive livestock farming and forestry are the main activities carried out here (NEMA 2004). Zones IV and V are sub-humid to semi-arid and have limited agricultural potential with only drought-resistant crops doing well. Ranching has the highest potential in this area. Zones VI and VII are arid and only extensive pastoralism is practised.

Table 2: Kenya's agro-ecological zone and agriculture potential

\begin{tabular}{|l|l|l|l|}
\hline $\begin{array}{l}\text { Agro-ecological } \\
\text { Zone }\end{array}$ & Potential land use & Area (000 ha) & \% of land \\
\hline I-III & $\begin{array}{l}\text { Medium to high: agriculture, livestock } \\
\text { (intensive), forestry }\end{array}$ & 860 & 15 \\
\hline IV-V & $\begin{array}{l}\text { Marginal to medium: agriculture } \\
\text { (drought-resistant crops) livestock } \\
\text { (ranching) }\end{array}$ & 11,500 & 20 \\
\hline VI-VII & $\begin{array}{l}\text { Marginal: livestock (extensive } \\
\text { pastoralism) }\end{array}$ & 37,400 & 65 \\
\hline Total & & $\mathbf{5 7 , 5 0 0}$ & $\mathbf{1 0 0}$ \\
\hline
\end{tabular}

Source: NEMA, 2004 


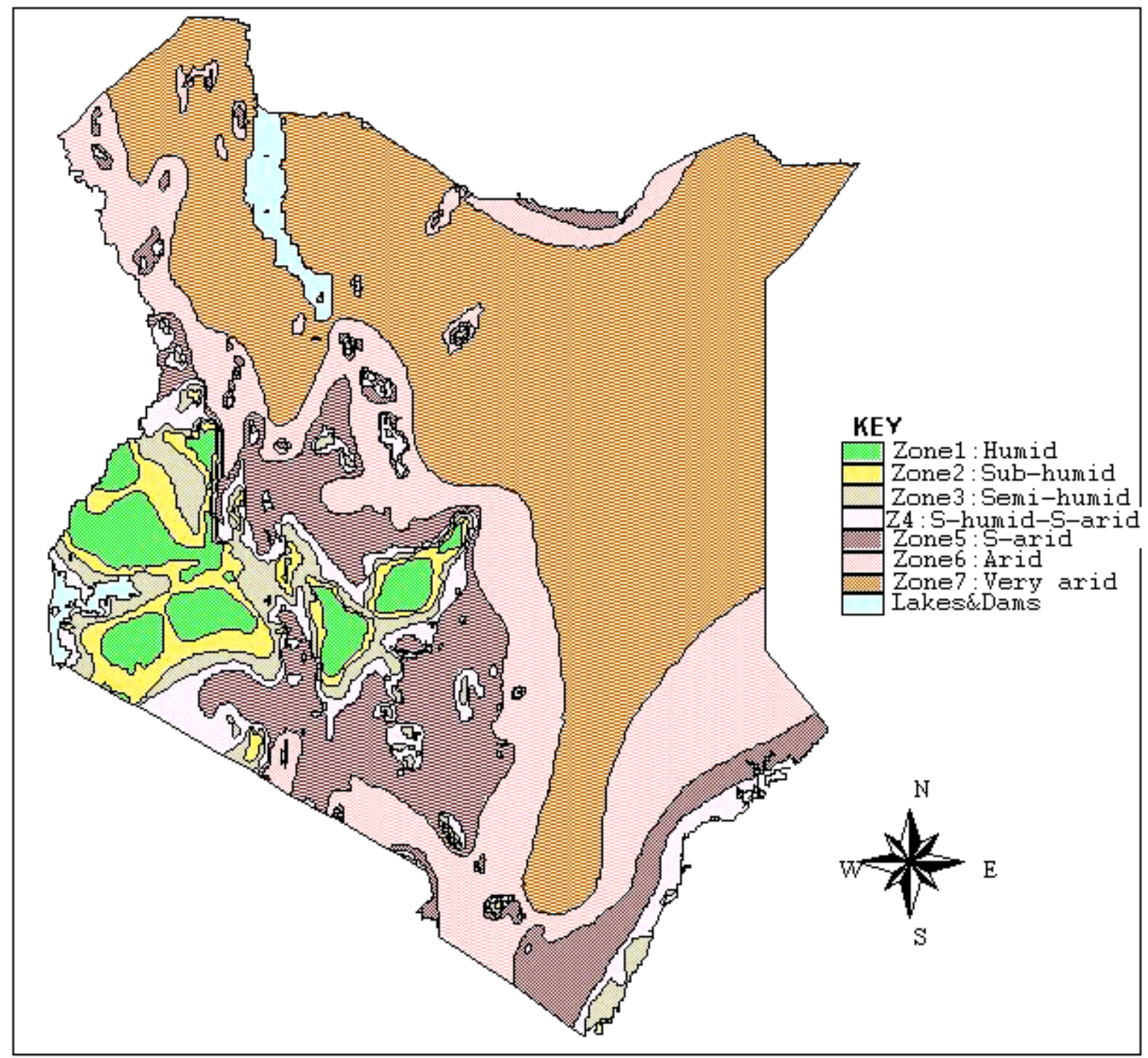

Source: http://www.fas.usda.gov

Fig. 1: Agro-ecological zones of Kenya

Agriculture is the leading sector of the national economy, employing about $75 \%$ of the population and accounting for $22 \%$ of the country's GDP and $60 \%$ of foreign exchange earnings (CIA 2011). Out of 9.4 million hectares of potentially cultivable land, only 2.8 million hectares are devoted to agriculture (GOK 2007). Even though certain areas endure arid and semi-arid conditions, most cropping systems are rain fed, and irrigation development remains quite limited. Eighty percent $(80 \%)$ of the farmers practise subsistence farming mainly producing maize, beans, sorghum, millet, onions, peas and other traditional crops for self consumption (MOA 2009). The main cash crops grown are coffee, tea, sisal, cotton, pyrethrum, rice, sugarcane and horticultural products meant for the export market like flowers, green beans and other vegetables (MOA 2010). 


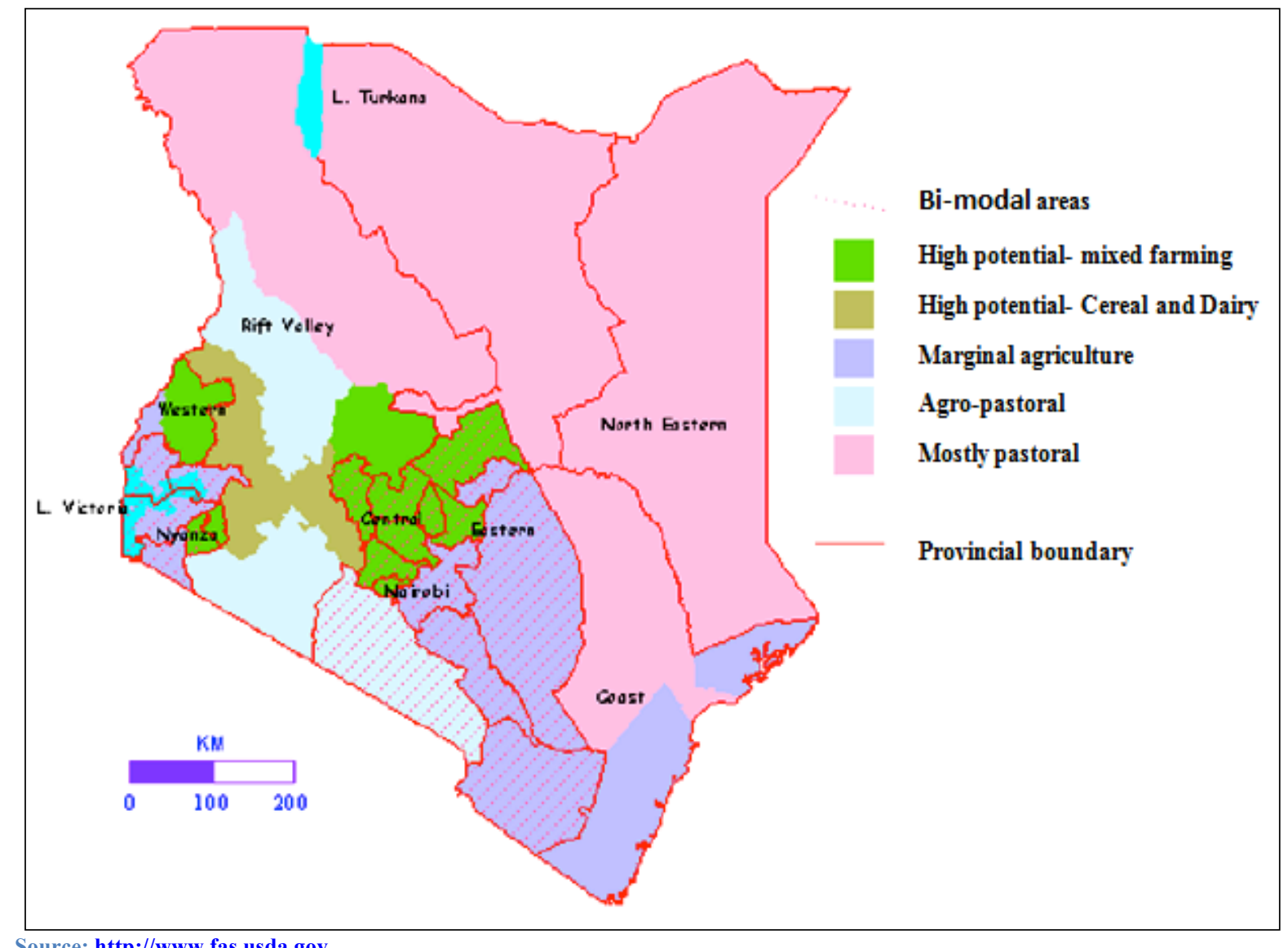

Ww.fas.usda.gov

Fig. 2: Kenya's production/livelihood systems

\section{POTENTIAL SUPPLY OF BIOFUEL FEEDSTOCK}

There are several crops currently grown in Kenya that can serve as feedstocks for either bioethanol or biodiesel. For the purpose of this report, only the major feedstocks, and specifically those that can be sustainably produced without resulting in food crises have been considered. The feedstocks analyzed for bioethanol are sugarcane, sweet sorghum and cassava, while those analyzed for biodiesel are jatropha, castor, croton and sunflower.

\subsection{Biodiesel feedstocks}

\subsubsection{Jatropha}

Jatropha (Jatropha curcas) is a multi-purpose, shrubby tree belonging to the Euphorbiaceae family. It is native to Mexico or Central America, but now thrives in many parts of the tropics and sub-tropics in sub-Saharan Africa and Asia. It has multiple uses as a biofuel source (as straight vegetable oil or biodiesel after transesterification) while the seedcake after pressing to remove the oil can be directly used as fuel or fertilizer. It can also be used as traditional medicine as a laxative, emetic, for cough treatment and healing wounds (Crothers 1998; Heller 1996; Thomas 1989). It can also be used to produce a dye which is used to give tan and brown shades, and for making ink. The bark yields about 37\% tannin. The plant has also been used in vanilla farms to support vanilla in some parts of Kenya and Tanzania, while other farmers have planted it as a live fence or for soil erosion control. It did not gain much importance in Kenya until 2005-2006 when some NGOs started promoting it as a biofuel feedstock mostly in the arid and semi-arid parts of Kenya. 

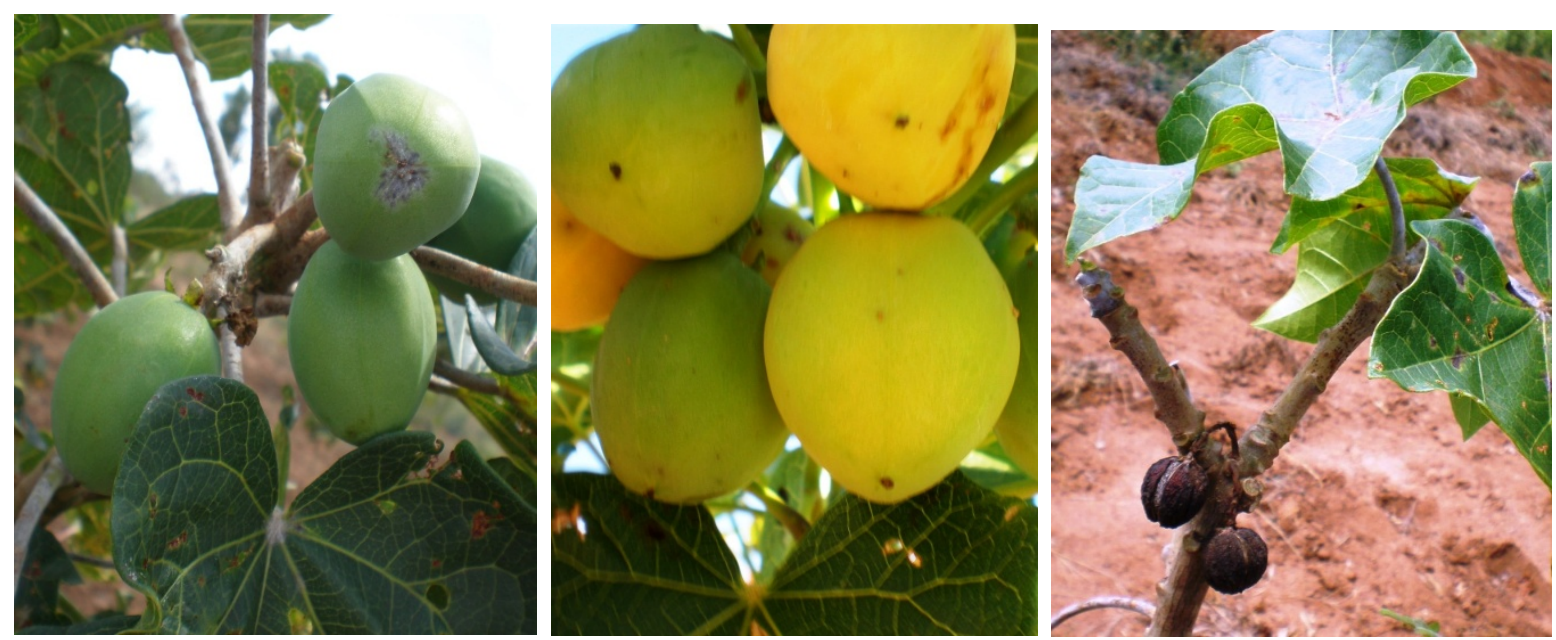

Source: Author

Fig. 3: Jatropha curcas at various stages of development in Kibwezi, Kenya

The plant can reach a height of 3-5m under normal conditions, and as high as $8-10 \mathrm{~m}$ under favourable conditions. It can bear seeds of variable size and oil content for up to 40-50 years. Once established, the plant can endure drought as it stores nutrients and water in its stem. The seeds usually contain between $27-40 \%$ oil. During its early promotion phase, it was claimed that it had a wide adaptability to diverse climatic zones and soil types, short gestation period, easy multiplication, drought tolerance, did not compete with food production, and was resistant to pests and diseases. However, these claims have been proved wrong with time as more farmers adopted the crop, a factor that has led to frustration and even abandonment of the crop altogether (GTZ 2009a).

The oil extracted from the seed can be used directly as straight vegetable oil (SVO) in adapted diesel engines to power local grain mills, oil presses, water pumps and small electricity generating plants. In Tanzania, trials of using it in specially made lamps and stoves have proved that it can be used to displace kerosene in areas not supplied with electricity (Wiskerke 2008). This makes it a particularly attractive investment in remote areas.

In the transport industry, the oil can be used to power modified diesel engines by using a dualtank system so that the engine can be started with conventional diesel. Furthermore the oil can also be blended with diesel and used in diesel engines. A blend of up to $25 \%$ can run the engine without any modifications. Finally, jatropha oil can be converted to biodiesel by the chemical process of transesterification. In this process, jatropha oil is mixed with methanol and caustic soda. However, such a process is rather capital intensive and can only be realized on a larger scale (van Eijck 2007).

\section{Agronomy}

Table 3: Agronomic parameters for jatropha

\begin{tabular}{|l|l|l|}
\hline Agronomic parameters & Overall range & Optimal range \\
\hline Annual temp $\left({ }^{\circ} \mathrm{C}\right)$ & $12-32$ & $19.3-27.2$ \\
\hline Annual rainfall $(\mathrm{mm})$ & $480-2380$ & $1000-2000$ \\
\hline Soil $\mathrm{pH}$ & $6-7$ & 6.5 \\
\hline Altitude & $0-1650$ & - \\
\hline Climate & Warm and humid climate \\
\hline Soil & Well drained loamy sand and sandy loam soils \\
\hline
\end{tabular}

Source: Muok et al 2010 
It is important to note that jatropha has not been fully domesticated hence its agronomic conditions are not scientifically proven but have only been derived from areas where the crop has been found growing naturally. The plantation is normally established by raising seedlings in a nursery. It is reported that plants propagated by seed have a longer lifespan of 50 years while those propagated by cuttings have a shorter lifespan of only 15 years (Nyamai and Omuodo 2007; Githunguri et al 2008). The yields from plants propagated by cuttings are also said to be lower and the mortality rate higher. To maximize seed production, proper pruning is necessary especially of the terminal bud to ensure the shrub adds more branches and has minimal vertical growth (Mshanga 2007). Fertilizer should be applied annually to sustain optimal seed yield. In the first five years, the shrubs can easily be intercropped with crops like beans and other legumes. Seed yields are only expected in year 3-4 and will reach a maximum in year 8-10 (Wiskerke 2008; GTZ 2009a).

\section{Agricultural potential and suitability in Kenya}

In Kenya, jatropha is mainly grown in Kitui, Namanga, Kajiado, Malindi, Nyanza, Nakuru, Marakwet, Naivasha, in the coastal regions and in Meru. In the past few years a lot of research on jatropha has been done in the country to understand its agronomic factors and evaluate its performance in a bid to separate fact from fiction. As a result, sizeable information is currently available, but due to the young age of the plantations in Kenya, there is still minimum data on productivity. Several organizations led by the Kenya Agricultural Research Institute (KARI) are currently conducting research on the best practices as far as cultivation of jatropha is concerned.

Recent research on environmental suitability commissioned by UNEP and Policy Innovation Systems for Clean Energy Security (PISCES) (Muok et al 2010), mapped the area potentially suitable for jatropha farming in Kenya based on the derived agronomic parameters. Based on the mapping, the area available for jatropha cultivation after zoning off protected zones, wetlands, slopes greater than $45 \%$ and wildlife conflict areas is approximately $149,302 \mathrm{~km}^{2}$ or $26.2 \%$ of the total Kenya surface area. However, some of this lies within the cultivated land, either for food or cash crops. The result showed that some areas in western Kenya and the coastal strip are highly suitable, while the whole of eastern Kenya is moderately suitable for jatropha farming.

Table 4: Jatropha suitability

\begin{tabular}{|l|l|l|}
\hline Suitability and zonation & Suitable area $\mathbf{( k m}^{\mathbf{2}} \mathbf{\text { O }}$ & of land surface area \\
\hline General suitability & 221,937 & 39.0 \\
\hline Suitable outside protected area & 177,700 & 31.2 \\
\hline Suitable within food crops areas & 58,184 & 10.2 \\
\hline Suitable within cash crops areas & 3,835 & 0.7 \\
\hline Suitable outside food and cash crops areas & 115,340 & 20.3 \\
\hline Suitable within cultivated areas & 62,017 & 10.9 \\
\hline Suitable within non-cultivated areas & 115,340 & 20.3 \\
\hline Suitable outside wildlife conflict areas & 153,811 & 27.0 \\
\hline Suitable outside wetlands & 153,651 & 27.0 \\
\hline Suitable outside animal movements paths $(3 \mathrm{~km})$ & 149,302 & 26.2 \\
\hline
\end{tabular}

Source: Muok et al, 2000 


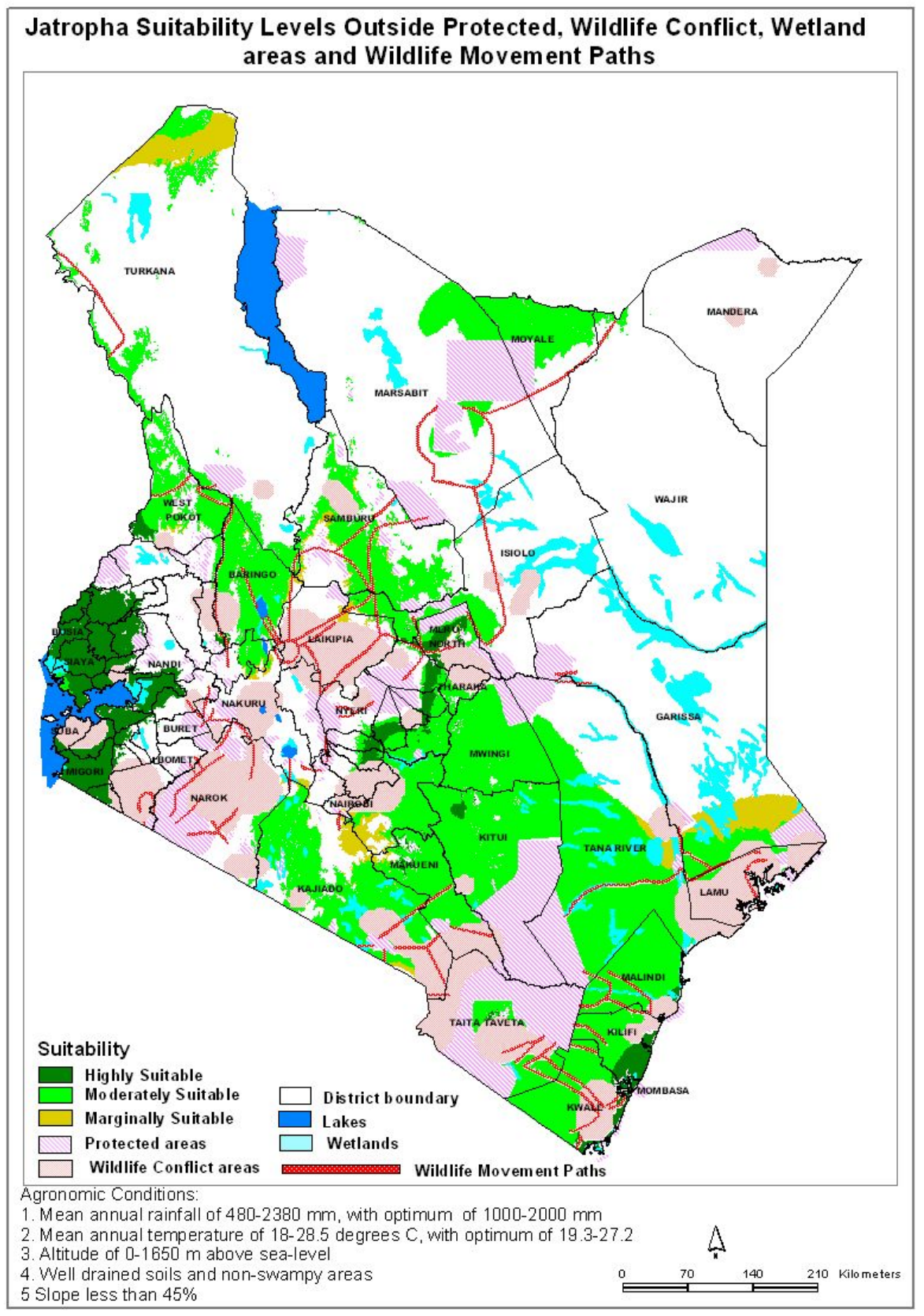

Source: ICRAF, GIS Unit

Fig. 4: Jatropha suitability levels

\section{Current status}

Jatropha activities in Kenya currently consist of small-scale production involving NGOs and private companies working with outgrowers and/or small demonstration/trial efforts. Most farmers have planted jatropha in parcels of land that range from half acre to five acres as a mono-crop or intercrop with various crops such as maize, beans and other legumes and often with banana and vanillas. Others have established it for a long time as a live fence or hedge, to prevent animals from straying into their farmlands and destroying crops (GTZ 2009a). A few foreign companies have in the past attempted to negotiate with the authority to develop jatropha curcas plantations for biodiesel production on semi-arid land owned by the government or large private ranches (GTZ 2009). The latest involves Bedford Biofuels, a foreign company that plans to invest about US\$ 3.6 million to develop an estimated area of 
64,000 hectares into jatropha plantation in the Tana Delta (Bedford Biofuels 2010). Their proposed plan is under extensive review, in response to concerns raised by conservationists.

Other notable developments include the setting up of the Jatropha Support Programme (JSP) in 2008 to research on different aspects of jatropha in Kenya, Uganda and Tanzania supported by DEG (Deutsche Investitions - und Entwicklungsgesellschaft $\mathrm{GmbH}$ ). The programme is a public-private partnership between nine companies in Eastern Africa and the German Government through DEG. Under the programme, field trials were established to help gain practical understanding of the commercial viability of jatropha as a first generation biodiesel fuel stock in Eastern Africa (JSP 2011). The Ministry of Energy (MOE) also reported that it has started demonstrations plots in all its energy centres to research and educate farmers on jatropha farming (MOE 2011).

In terms of biofuel production, there is currently no commercial processing hence no market for the harvested seeds. Several initiatives are however being set up in the country to rectify this situation. The MOE is in the process of helping jatropha farmers in Makueni procure equipment for oil extraction to be used as SVO. In Mpeketoni, jatropha farmers supported by Norwegian Church Aid, Green Africa Foundation (GAF) and ESDA are in the process of acquiring a Kenya Power and Lighting Company (KPLC) diesel electricity generator which can use SVO to generate electricity and feed it into the grid (MOE 2011). Kenya Industrial Research and Development Institute (KIRDI) has also done extensive research on transesterification and is currently concentrating on designing locally made equipment that can be used to process the oil (KIRDI 2011). However, no commercial transesterification of jatropha oil was reported in Kenya by the time this research was done. The MOE is also contemplating setting up oil presses in all its energy centres, procure seeds from the farmers and use the oil to generate electricity for their own use, while at the same time passing on the skills to the farmers (MOE 2011).

\subsubsection{Castor}

Castor (Ricinus communis) is a perennial shrub from the Euphorbiaceae family with green, reddish to purple stems and finger-like leaves that likely originated in Abyssinia, or modern day Ethiopia. In the wild, castor can reach up to $9 \mathrm{~m}$, but cultivated varieties generally grow to between 1-4m (MOE/GTZ 2008). Perennial varieties of castor are relatively drought tolerant because of their deep taproots which can extract water from the sub-soil.

The plant is indigenous to East Africa but is considered invasive in other parts of the world. It can be grown as an annual or perennial depending on the variety. It is generally easy to cultivate with minimum care and inputs but yields increase with more intensive management. It is suitable for manual harvesting as well as mechanization on a large scale. Castor does best on fertile, well-drained soil, and therefore it may compete with food production on arable land (MOE/GTZ 2008). 

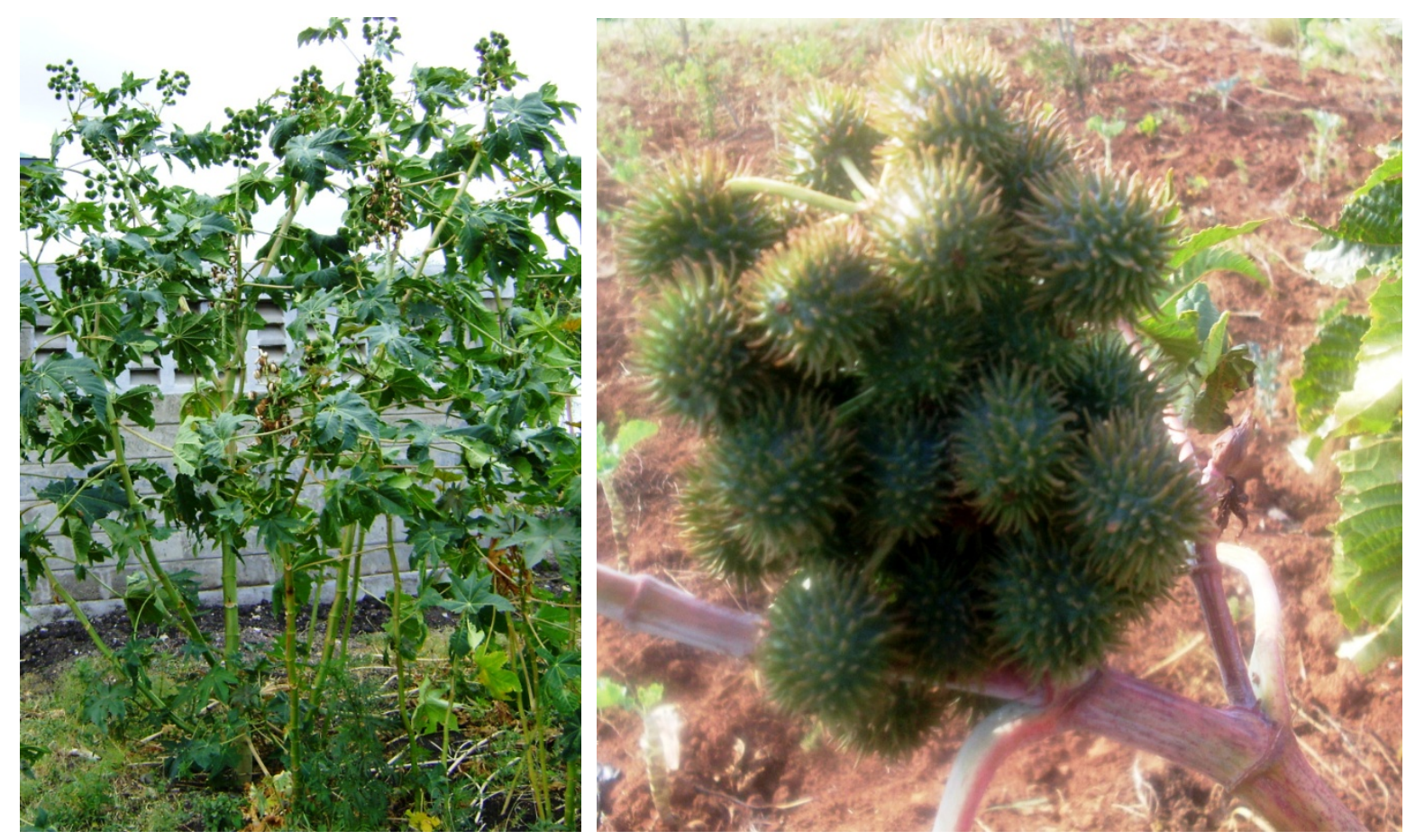

Source: Author

Fig. 5: Castor plant (left) and fruits (right) in Central Province, Kenya

Traditionally, castor oil was used to cure hides and for cosmetic purposes. Since it contains ricinoleic acid, castor can be used in many industrial products e.g. hydraulic fluids, jet engine lubricants, plastics, synthetic textiles, soap and paint. The cellulose from the stem is used to make cardboard and paper products.

The seed contain $40-50 \%$ oil which can be extracted by crushing in a conventional oil press. The oil can be used in diesel engines but its viscosity needs to be adjusted because it is too high (Muok et al 2010). Castor oil can also be used to lubricate moving parts in machinery. Due to its many other industrial uses, castor oil fetches a much higher price than most other biodiesel oils hence experts argue that is better left for industrial use than as a biofuel (KIRDI 2011).

Agronomy

Table 5: Agronomic parameters for castor

\begin{tabular}{|l|l|l|}
\hline Agronomic parameters & Overall range & Optimal range \\
\hline Annual temp $\left({ }^{\circ} \mathrm{C}\right)$ & $15-39$ & $20-30$ \\
\hline Annual rainfall $(\mathrm{mm})$ & $400-2000$ & $750-1000$ \\
\hline Altitude & $0-2000$ & $300-1800$ \\
\hline Climate & Warm and humid climate \\
\hline Soil & Well drained soils friable, sandy loams \\
\hline Maturity & 5-6 months \\
\hline
\end{tabular}

Source: Muok et al, 2010

Castor seeds are normally propagated by direct sowing about $6-8 \mathrm{~cm}$ deep in rows $0.9-1.2 \mathrm{~m}$ and spaced $0.2-0.6 \mathrm{~m}$ in between rows. Seeds should be treated with fungicide before planting to avoid root rot and alterneria blight especially in cold areas with high soil moisture content (MOE/GTZ 2008). The plant is highly susceptible to pests, so fortnight spraying is recommended from flowering to harvesting (GTZ 2009a). It also requires two weedings, one 
before planting and one during mid-growth. The crop is normally intercropped with other crops like maize, beans, potatoes, sorghum and bananas.

\section{Agricultural potential and suitability}

Castor is one of the most widespread biofuel crops in terms of suitability in Kenya. Its natural distribution range spreads from Western, Rift Valley, Central, Eastern to Coastal Provinces covering an area of $240,494 \mathrm{~km}^{2}$ or $42.2 \%$ of the country (Muok et al 2010). However when protected areas, wildlife conflict areas, animal movement paths and slopes greater than $45 \%$ are zoned out, the land available for castor cultivation reduces to $159,115 \mathrm{~km}^{2}$ or $28.0 \%$ of the total Kenya surface area.

Castor offers less competition to cash crop production in terms of the area but its highly suitable areas are scattered in agriculturally marginal to medium potential areas which could offer competition to food crops like maize and beans (Muok et al 2010).

Table 6: Proportion of land suitable for castor cultivation in Kenya

\begin{tabular}{|l|l|l|}
\hline Suitability and zonation & Suitability area $\left.\mathbf{( k m}^{2}\right)$ & \%of land surface area \\
\hline General suitability & 240,494 & 42.2 \\
\hline Suitable outside protected area & 192,303 & 33.8 \\
\hline Suitable within food crops areas & 65,324 & 11.5 \\
\hline Suitable within cash crops areas & 5,377 & 0.9 \\
\hline Suitable outside food and cash crops areas & 121,236 & 21.3 \\
\hline Suitable within cultivated areas & 70,854 & 12.4 \\
\hline Suitable within non-cultivated areas & 121,236 & 21.3 \\
\hline Suitable outside wildlife conflict areas & 166.047 & 29.2 \\
\hline Suitable outside wetlands & 163,603 & 28.7 \\
\hline Suitable outside animal movements paths $(3 \mathrm{~km})$ & 159.115 & 28.0 \\
\hline
\end{tabular}

Source: Muok et al, 2010 


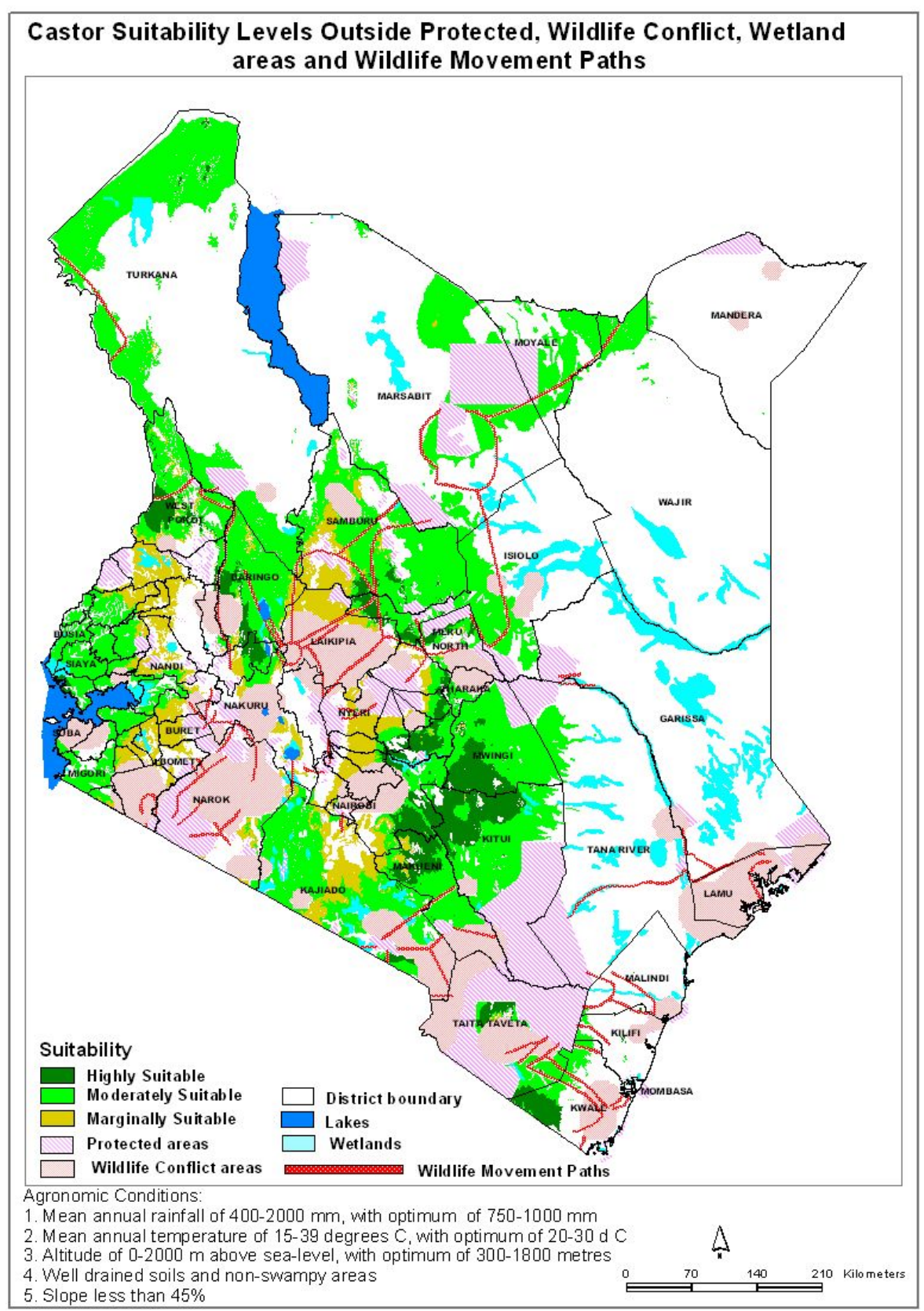

Source: ICRAF GIS Unit

Fig. 6: Castor suitability levels

\section{Current status}

Commercial castor farming is non-existent in Kenya though there were reports of castor farming in the country for many years. In the 1970s and 1980s, there was widespread interest in castor growing due to promotion by the government, but this failed due to lack of market (GTZ 2009a). Currently, castor can be seen growing in the wild like a weed but there are some people who grow it for soil erosion control or for oil extraction to make homemade lotions. The Kenya Agricultural Research Institute has developed about four local hybrid varieties but they have not yet been bulked for distribution to farmers for planting. 
There is a huge market for castor oil, both locally and internationally, but Kenya has not been able to tap into this market. In 2006, Kenya imported 428 tonnes of castor oil for industrial purposes due to lack of locally processed oil (GTZ 2009a). However, experts from the Kenya Industrial Research and Development Institute feel that with the high value of castor oil for industrial processes, it would be better if the crop is not promoted for biodiesel production but rather for industrial purposes which would fetch more income for the farmers.

\subsubsection{Croton}

Croton (Croton megalocarpus) is a hardy, fast-growing deciduous tree with distinctive layering of branches, growing into a straight stem of between $6-36 \mathrm{~m}$. The tree is indigenous to East Africa where it has been widely grown in mountainous regions. It is believed that the centre of its endemism is the Aberdare Mountains of Kenya (Muok et al 2010). It has a dark grey or pale brown, rough and longitudinally cracking bark with a strong pepper-like spicy odour. It has variable, long, oval-shaped leaves and grey, woody, ovoid fruits measuring about 2-4 by $1.5-3 \mathrm{~cm}$ (GTZ 2009a). Each fruit contains three flattened, greyish-brown seeds.
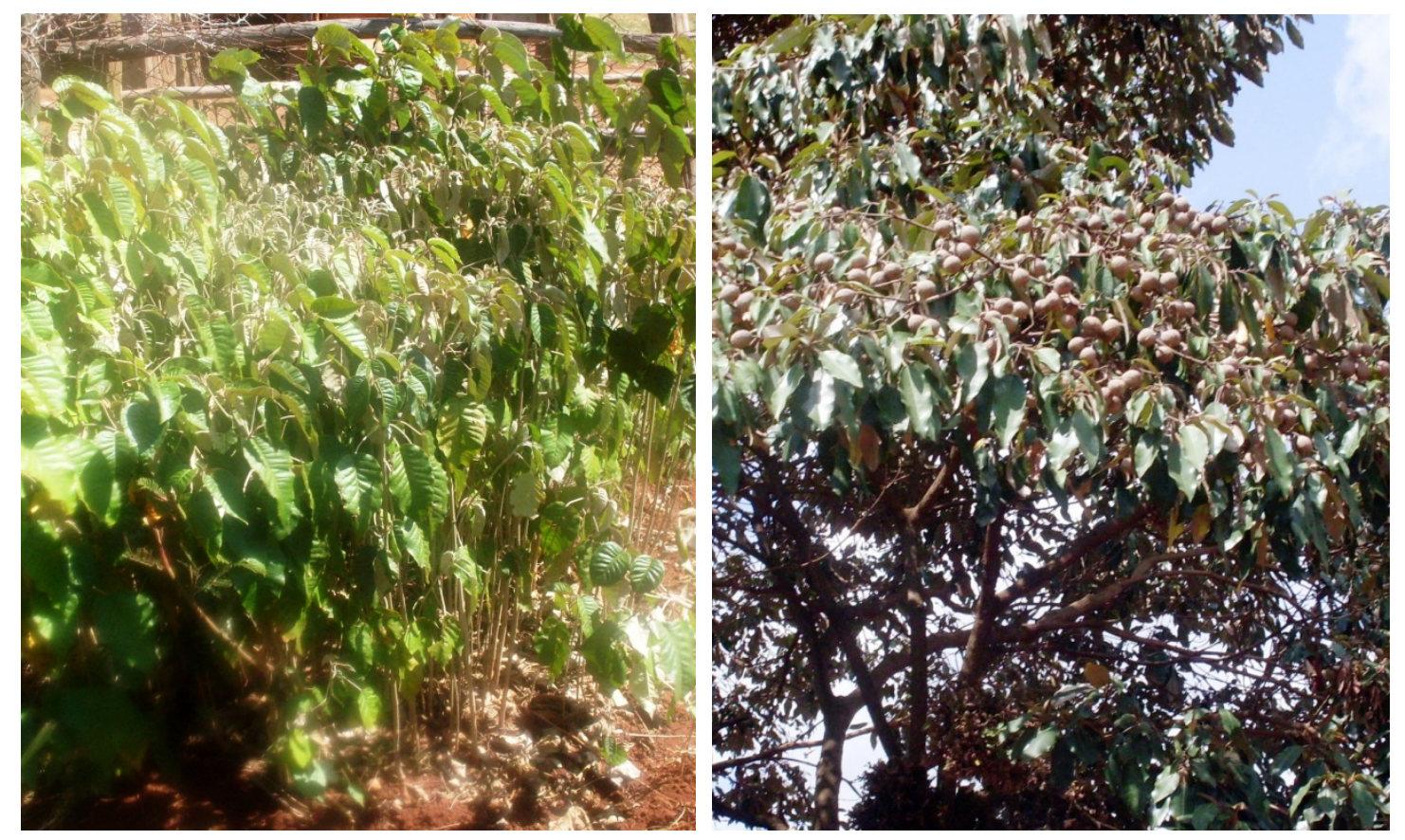

Source: Author

Fig. 7: Croton seedlings (left) and a fruiting croton tree (right)

Croton starts to seed after four years and produces up to $25 \mathrm{~kg}$ of seed per tree. The seeds have $30 \%$ of highly unsaturated oils suitable for biodiesel. The seedcake cake is highly rich in protein and is commonly used as poultry feed (Muok et al 2010). The tree can grow up to 50 years from planting after which it can be felled and used for making furniture, firewood or charcoal. The tree has also been extensively grown as a windbreak or boundary marker in many rural areas (MOE/GTZ 2008). 
Table 7: Croton agronomic parameters

\begin{tabular}{|l|l|l|}
\hline Agronomic parameters & Overall range & Optimal range \\
\hline Annual temp $\left({ }^{\circ} \mathrm{C}\right)$ & $11-26$ & $16-22$ \\
\hline Annual rainfall $(\mathrm{mm})$ & $800-1900$ & $1000-1400$ \\
\hline Altitude & $1200-2450$ & $1200-1600$ \\
\hline Soil & Light deep and well drained soils. \\
\hline
\end{tabular}

Source: Muok et al 2010, GTZ 2009a

Croton performs best in agro-ecological zones with bimodal rainfall with cool, humid temperatures. The tree is best propagated through direct sowing but vegetative propagation is also possible through grafting or cuttings. The seeds are extracted by cracking the shell and drying them to 5-9\% moisture content. Normally, the seeds germinate within 35-45 days, with an expected germination rate of $95 \%$ for mature and healthy seed lots (GTZ 2009a). Flowering starts at the end of April and May producing mature seeds in October through December or January through February depending on the agro-ecological zone. The trees can be intercropped with other crops such as maize, beans and potatoes. Intercropping croton with maize and legumes is recommended. Since it has deep taproots it offers limited competition to other crops and the long taproots help access sufficient soil nutrients making them available to crops through litter fall (Muok et al 2010).

\section{Agricultural potential and suitability}

Croton is widely grown in diverse ecological zones ranging from Kakamega, Nairobi, Nyeri to Taita and is mostly cultivated near homesteads, in croplands water courses or in swamps (GTZ 2009a). However, its natural distribution range is mainly in central and western Kenya. Based on environmental suitability the total suitable area is $62,773 \mathrm{~km}^{2}$ which is about $11 \%$ of the total Kenya surface area. This reduces to $35,254 \mathrm{~km}^{2}$ or $6.2 \%$ when protected areas, wildlife conflict areas, wetland areas, important bird areas, slopes more than $45 \%$ and animal movement paths are zoned out (Muok et al 2010).

The crop if wholly adopted as a plantation monocrop could offer competition to cash crops because in the central and part of the western regions (e.g. Kisii, Bomet and Kericho), the areas suitable for its production lies within the same range as cash crops such as coffee and tea. The entire land suitable for croton growing also lies within areas classified as arable land whether cultivated or uncultivated (Muok et al 2010).

Table 8: Proportion of land suitable for croton cultivation in Kenya

\begin{tabular}{|l|l|l|}
\hline Suitability and zonation & Suitability area $\left.\mathbf{( k m}^{\mathbf{2}}\right)$ & \% of land surface area \\
\hline General suitability & 62,773 & 11.0 \\
\hline Suitable outside protected area & 46,266 & 8.1 \\
\hline Suitable within food crops areas & 32,842 & 5.8 \\
\hline Suitable within cash crops areas & 4,415 & 0.8 \\
\hline Suitable outside food and cash crops areas & 8,654 & 1.5 \\
\hline Suitable within cultivated areas & 37,611 & 6.6 \\
\hline Suitable within non-cultivated areas & 8,654 & 1.5 \\
\hline Suitable outside wildlife conflict areas & 35,950 & 6.3 \\
\hline Suitable outside wetlands & 35,734 & 6.3 \\
\hline Suitable outside animal movements paths $(3 \mathrm{~km})$ & 35,254 & 6.2 \\
\hline
\end{tabular}




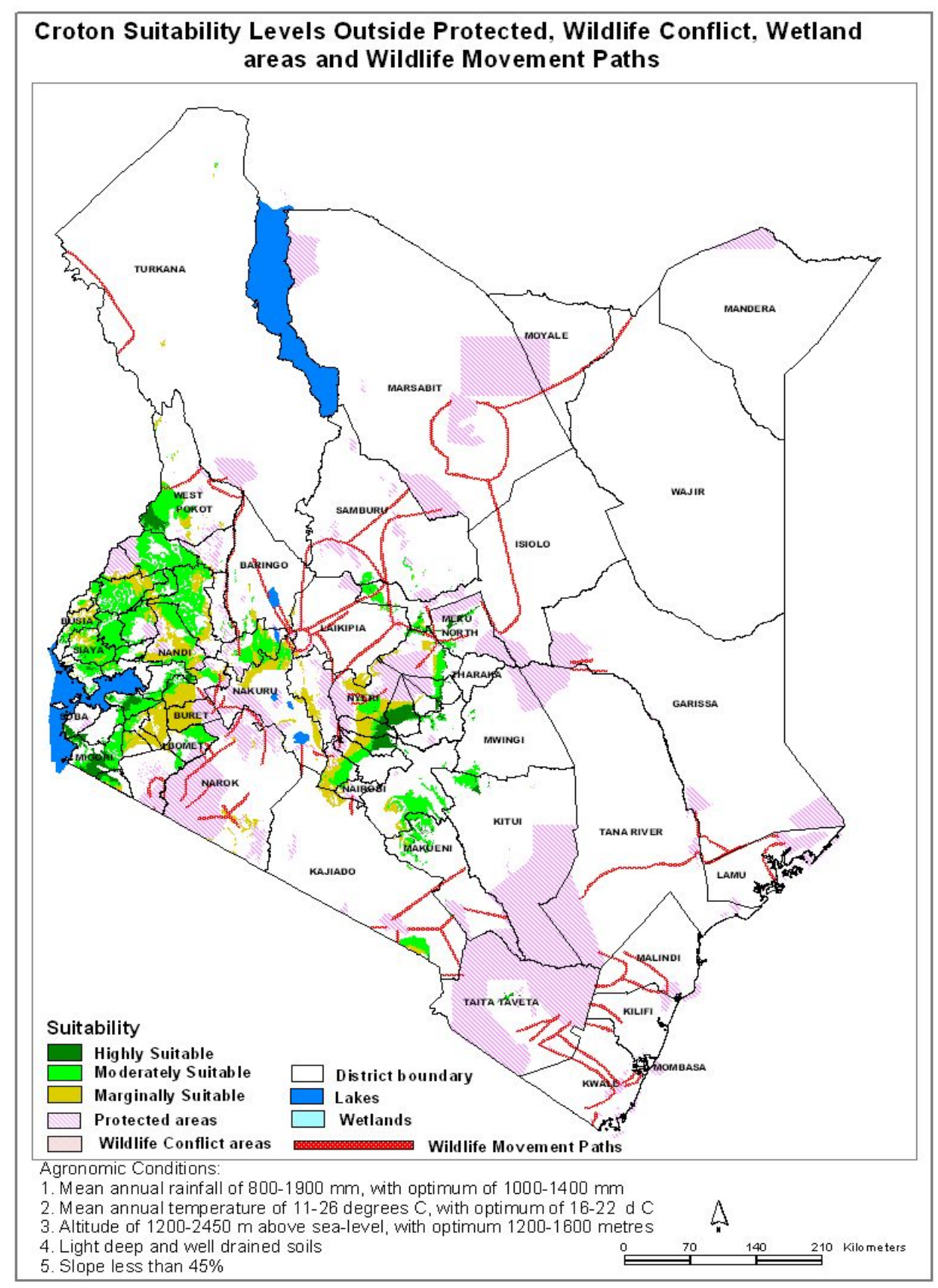

Source: ICRAF GIS Unit

Fig. 8: Croton suitability levels

\section{Current status}

Croton in Kenya is not grown as a biodiesel crop. Most people grow it for shade, firewood and construction materials although no formal tress census has been done to ascertain the actual number. There are no croton plantations, with many farmers having a few trees spread across their farms while others plant along the boundaries (MOE/GTZ 2009). As such, it is difficult to establish a processing plant for biodiesel due to scattered feedstock making transportation expensive. KEFRI and KARI have been doing research on croton for some years with the aim of popularizing it as a multipurpose crop. However, if it is to be commercially exploited for biodiesel production, more farmers concentrated in one area need to adopt the crop to raise enough feedstock. 
In 2008 during the fuel crisis, an NGO in Kieni area in Central Province called the Help Self Help Centre (HSHC) was reported to be buying croton seeds from farmers who collect them from neighbourhoods and forests for making biodiesel. The project, according to the staff, is still ongoing and they buy the seeds at KSh 6 per $\mathrm{kg}$. The centre has a capacity of 800 litres of biodiesel per day but produces 400 litres due to shortage of feedstock. The fuel was mostly sold to motorists in Kieni. The project was supported by Solarix Netherlands and Kenya School Project (USA) among others.

\subsubsection{Sunflower}

Sunflower (Helianthus annuus) is an annual plant that originated from Central America that possesses a large inflorescence (flowering head). It got its name from its huge fiery blooms, whose shape and image is often used to depict the sun (Wikipedia). It has a rough, hairy stem, broad, coarsely toothed, rough leaves and circular heads of flowers. The heads consist of 1000-2000 individual flowers joined together by a receptacle base. A mature crop grows to $0.6-4.5 \mathrm{~m}$ high depending on the variety and the flowers are about $30 \mathrm{~cm}$ in diameter with yellow petals forming an outer ring (Muok et al 2010).

Sunflower is widely adapted and one of the major edible oil crops grown in Kenya. It was introduced in Kenya as an edible oil crop and is regarded as a high value cash crop (Okok et al 2008). Sunflower has deep taproots that enables it extract water from the subsoil hence it tends to be drought tolerant (Acland 1971).

Sunflower is mostly used for edible oil extraction while the seedcake is used in animal feed formulations. Since the oil has good drying properties that do not affect colour, it is used to make some paints and varnishes for the niche market. The seeds can also be eaten as a snack (Muok et al 2010).

Agronomy

Table 9: Sunflower agronomic parameters

\begin{tabular}{|l|l|l|}
\hline Agronomic parameters & Overall range & Optimal range \\
\hline Annual temp $\left({ }^{\circ} \mathrm{C}\right)$ & $20-28$ & - \\
\hline Annual rainfall $(\mathrm{mm})$ & $500-1200$ & - \\
\hline Altitude & $0-2600$ & - \\
\hline Soil & Well drained loam soils \\
\hline Maturity period & $5-10$ months \\
\hline
\end{tabular}

Source: Muok et al 2010, GTZ, 2009a

Sunflower is propagated by direct sowing and this should be done during the rains to ensure maximum yields (Drumnet 2010). The crop does well in well-drained loam soils where annual rainfall ranges between $500-1200 \mathrm{~mm}$. The time for planting sunflower should allow for enough rain at flowering so that the crop can mature during a dry spell (Muok et al 2010). Inter-row spacing is recommended at $75 \mathrm{~cm}$ while intra-row spacing is recommended at $30 \mathrm{~cm}$. The crop should be weeded at regular intervals until it is $90 \mathrm{~cm}$ high. Thereafter the weeds are suppressed by shading. Soil should be drawn up around the stems during weeding to avoid lodging. Sunflower can be intercropped with legumes which provide good groundcover. It responds well to fertilizer (IDRC 1998). 
KARI has bred the sunflower and come up with different varieties that suit different agroecological zones. These include early to late maturing varieties that take 100 to 140 days to reach maturity after planting that were developed at the KARI Njoro Station (Mathu et al 2007). Drumnet, an organization that works in conjunction with Bidco Oil Refineries introduced a new sunflower variety, Pannar 7369, in Nyanza and through trials established that the variety grew to 6 feet in height with heads between 9-12 inches in diameter. In addition, the crop yielded an average of $550 \mathrm{~kg}$ per acre as compared to $150-200 \mathrm{~kg}$ for other varieties that the farmers planted (Drumnet 2010).

\section{Agricultural potential and suitability}

Sunflower is a crop that has been found to do well in agro-ecological zones with high to medium rainfall and deep loamy soils in Kenya. These include the Coast Province, parts of Eastern, Nyanza, Western and Central Provinces.

Based on the environmental suitability the suitable areas for growing sunflower is $140,003 \mathrm{~km}^{2}$ or $24.6 \%$ of the country. When the protected areas, wildlife conflict areas, wetland areas, important bird areas, slopes more than $45 \%$ and animal movement paths are removed, the total area suitable for sunflower farming is $86,414 \mathrm{~km}^{2}$ or $15.2 \%$ of the total Kenya surface. Except for parts of coast, upper eastern around Mt. Kenya and small pockets of western regions, sunflower does not compete significantly with cash crop farming but all the suitable areas lie within arable land, both cultivated and uncultivated (Muok et al 2010).

Table 10: Proportion of land suitable for sunflower farming in Kenya

\begin{tabular}{|l|l|l|}
\hline Suitability and zonation & Suitability area $\mathbf{( k m}^{2} \mathbf{)}$ & \%of land surface area \\
\hline General suitability & 140,003 & 24.6 \\
\hline Suitable outside protected area & 104,574 & 18.4 \\
\hline Suitable within food crops areas & 43,246 & 7.6 \\
\hline Suitable within cash crops areas & 1,950 & 0.3 \\
\hline Suitable outside food and cash crops areas & 63,462 & 11.1 \\
\hline Suitable within cultivated areas & 45,231 & 7.9 \\
\hline Suitable within non-cultivated areas & 63,462 & 11.1 \\
\hline Suitable outside wildlife conflict areas & 90,289 & 15.9 \\
\hline Suitable outside wetlands & 88,986 & 15.6 \\
\hline Suitable outside animal movements paths $(3 \mathrm{~km})$ & 86,414 & 15.2 \\
\hline
\end{tabular}

Source: Muok et al 2010

\section{Current status}

Sunflower farming in Kenya is concentrated in Nyanza and Western Provinces. In 2003, over 3300 hectares were under sunflower in Nyanza and almost 2500 hectares in Western Province. Currently more people have adopted sunflower farming in Nyanza and Central due to its promotion by Bidco Oil Refineries which partnered with other organizations in its efforts to increase its edible oil raw material resource base (EPZA 2005). 


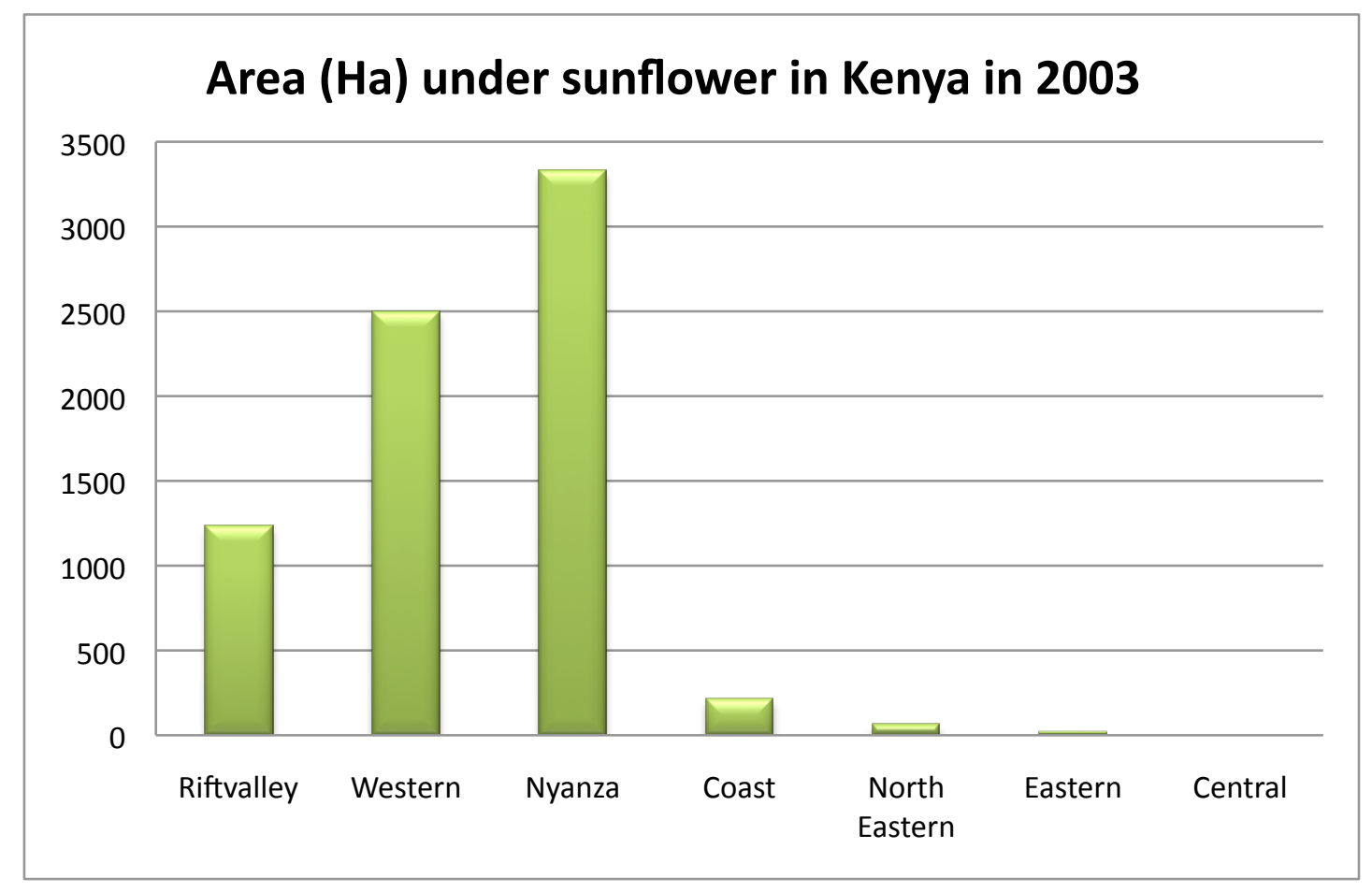

Source: EPZA, 2005b

Fig. 9: Area in Kenya under sunflower cultivation in 2003

In 2009, the Ministry of Agriculture reported that 108 tonnes of sunflower seeds were produced in the country while only 200kg were imported (MOA 2010). Most of these were absorbed by edible oil processing firms like Bidco Oil Refineries which make sunflower oil. However most of the sunflower is produced by small-scale farmers and in almost all cases, is intercropped with other crops. The low yields due to poor varieties that yield only $150-200 \mathrm{~kg}$ per acre is the main reason farmers have not fully accepted the crop, though the varieties promoted by organizations are high yielding (IDRC 1998; Drumnet 2010)

Sunflower has been identified as one of the crops with a huge potential for biodiesel production in Kenya but due to its wide uses and high cost, the likelihood of it being used to make biodiesel is marginal. Currently, a litre of sunflower cooking oil retails at about US\$2.3 compared to US\$1.2 for a litre of diesel.

\subsection{Bioethanol feedstocks}

\subsubsection{Sweet sorghum}

Sweet sorghum (Sorghum bicolor (L) Moench) is a plant that can be traced back to Egypt. The plant grows to around 0.6-5 $\mathrm{m}$ tall and the stem has sweet and juicy pith (Muok et al 2010). It was introduced in Kenya mainly for its grain which is used as food. However, its sweet juice from the stalk can be used for ethanol production. Sweet sorghum is drought resistant and has a short maturity period that can allow for 2-3 harvests a year. It is a $\mathrm{C}_{4}$ plant characterized by a high biomass sugar-yielding and photosynthetic efficiency (MOE/GTZ 2008).

Sorghum is mainly grown in the lower potential districts in Kenya where it plays a key role in ensuring food security. The grains are used to make cereals, snacks, bread and porridge 
(fermented and unfermented) while the stalks can be used as animal fodder and in the manufacture of paper and wallboards (Muok et al 2010). Ethanol from sweet sorghum has superior quality, lower sulphur content, high octane rating and is automobile friendly (up to $25 \%$ blending). Bagasse obtained after juice extraction has higher biological value, as it is rich in micronutrients making it suitable as organic manure and can also be used as feed or for power cogeneration.

When grown for bioethanol production, the first crop is usually left to grow to maturity and the grain harvested for food. This is positive in that it ensures food security thus eliminating the competition between food and biofuels. The potential grain yield is about 10-15 bags per hectare (MOE 2010). Thereafter the ratoon crops can be harvested twice or thrice a year for the stalks which are crushed to remove the juice for fermentation.

\section{Agronomy}

Table 11: Sorghum agronomic parameters

\begin{tabular}{|l|l|l|}
\hline Agronomic parameters & Overall range & Optimal range \\
\hline Annual temp $\left({ }^{\circ} \mathrm{C}\right)$ & $17-40$ & $22-35$ \\
\hline Annual rainfall $(\mathrm{mm})$ & $350-2380$ & $400-600$ \\
\hline Altitude & $0-2500$ & - \\
\hline Soil & Pellic vertisols & \\
\hline Maturity period & 4 months \\
\hline
\end{tabular}

The crop is best propagated through the seeds. The seed is cultivated in rows spaced $50-60 \mathrm{~cm}$ apart with hill-to-hill spacing of $12-15 \mathrm{~cm}$ (Rao et al 2008). Weeds in sorghum can be controlled through chemical sprays (pre-emergence herbicides are applied at most one day after sowing) and mechanically until the crop is 35-40 days old. The crop is affected by major pests at different stages of growth and they include cutworms, armyworms, wireworms and seed beetles. In areas where the humidity and rainfall are high sweet sorghum suffers from foliar diseases such as leaf blight and dwarf mosaic (Rao et al 2008).

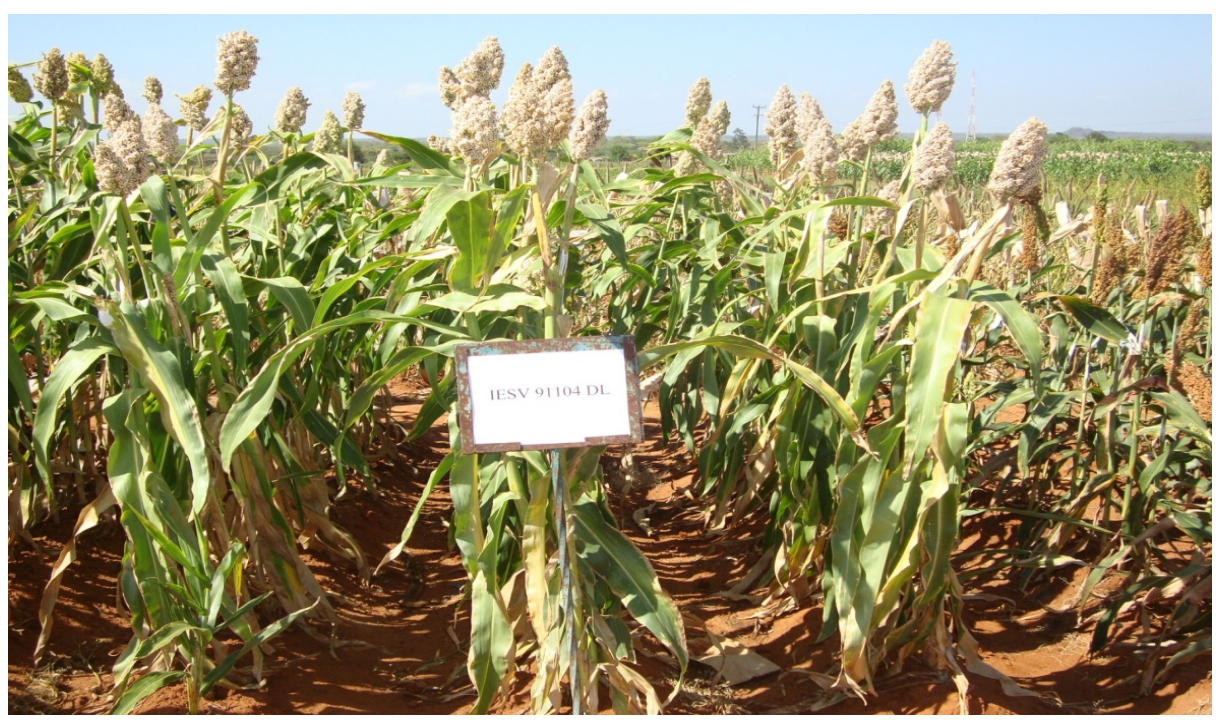

Source: ICRISAT

Fig. 10: A sweet sorghum trial plot 
The crop matures after four months and this can be established when a black spot appears on the grain at the lower end. The grain can be harvested either manually or using a combine harvester. The sweet sorghum stalks can be harvested for juice when its brix reaches $16-18 \%$ (Muok et al 2010).

\section{Agricultural potential and suitability}

In Kenya, sorghum is an important cereal in the medium and low altitude areas. O'Neill and Kamau (1990) estimated that 52\% of sorghum in Kenya is grown in Nyanza and $23 \%$ in Western Province. It is an important food crop around Lake Victoria region, an area where maize yields are relatively poor mainly due to erratic rainfall, pests and diseases (Wanyama et al 1995).

According to Muok et al (2010), sweet sorghum has the widest suitability area from western, central, eastern and coastal regions of Kenya estimated at $263,965 \mathrm{~km}^{2}$ or $46.4 \%$ of the total Kenya surface area. However, the suitable area reduces to $185,822 \mathrm{~km}^{2}$ or $32.6 \%$ of the total Kenya surface area when the protected areas, wildlife conflict areas, wetlands and animal movement paths are zoned off.

Table 12: Proportion of land suitable for sweet sorghum cultivation in Kenya

\begin{tabular}{|l|l|l|}
\hline Suitability and zonation & Suitability area $\left.\mathbf{( k m}^{2}\right)$ & \%of land surface area \\
\hline General suitability & 263,965 & 46.4 \\
\hline Suitable outside protected area & 206,574 & 36.3 \\
\hline Suitable within food crops areas & 53,204 & 9.3 \\
\hline Suitable within cash crops areas & 4,029 & 0.7 \\
\hline Suitable outside food and cash crops areas & 149,260 & 26.2 \\
\hline Suitable within cultivated areas & 57,332 & 10.1 \\
\hline Suitable within non-cultivated areas & 149,260 & 26.2 \\
\hline Suitable outside wildlife conflict areas & 182,758 & 32.1 \\
\hline Suitable outside wetlands & 179,260 & 31.5 \\
\hline Suitable outside animal movements paths $(3 \mathrm{~km})$ & 174,446 & 30.6 \\
\hline
\end{tabular}

Source: Muok et al 2010 


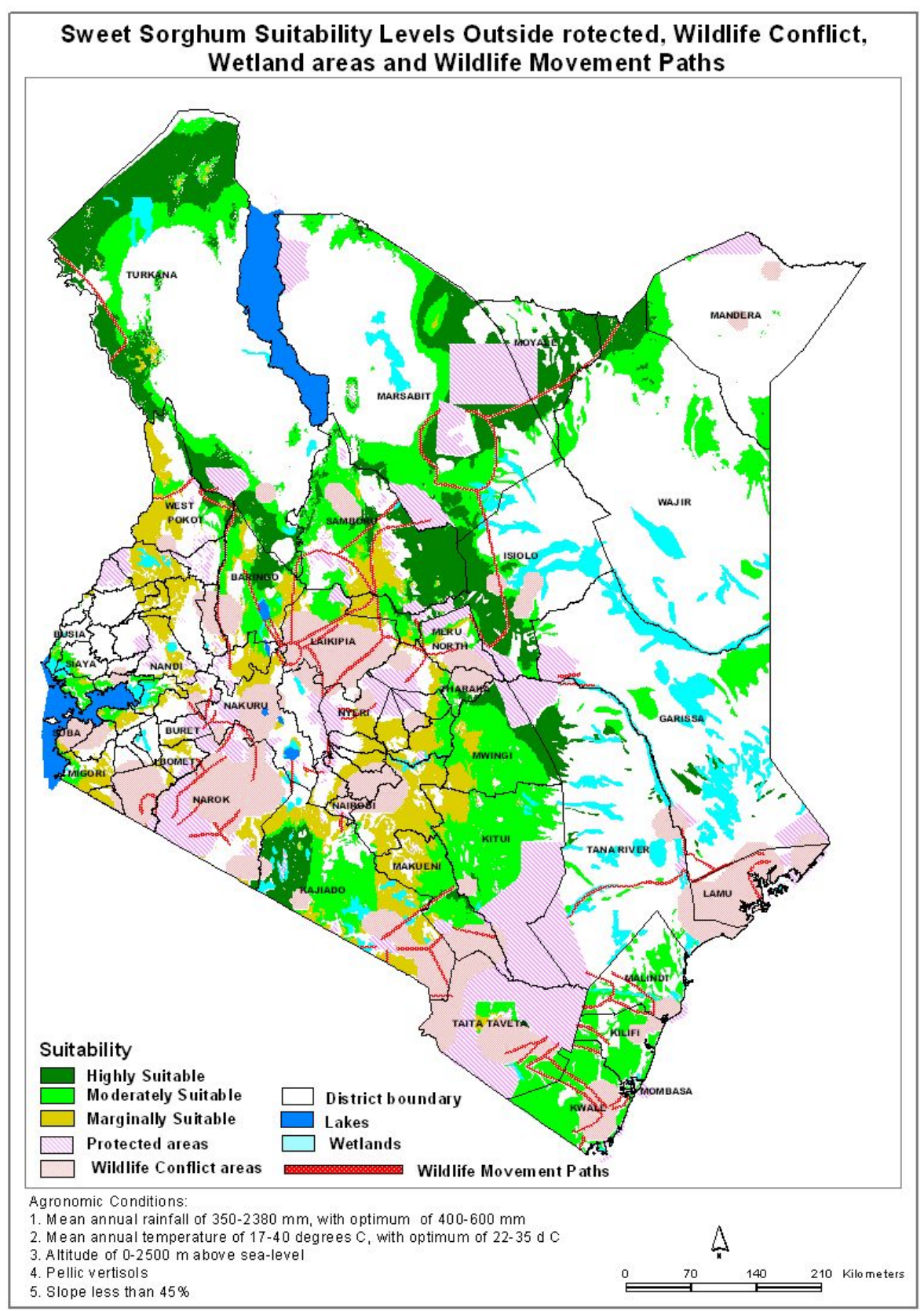

Source: ICRAF GIS Unit

Fig. 11: Sweet sorghum suitability levels

\section{Current status}

Production of sorghum in Kenya has been declining over the years both in terms of yields per hectare and total productivity. However, production increased by a dramatic $75 \%$ from 54.26 million tonnes in 2008 to 94.955 million tonnes in 2009. There was also a slight improvement on the yield per hectare to $621 \mathrm{~kg}$ but this was still lower though when compared with the 14.0 bags/hectare recorded in 2005 (MOA 2010). The area under the crop also registered an increased acreage to achieve 173,172 ha in 2009 due to it being promoted as a drought resistant and hence a primary poverty eradication vehicle in marginal areas. 
Table 13: National sorghum production 2005-2009

\begin{tabular}{|l|l|l|l|l|l|}
\hline Year & $\mathbf{2 0 0 5}$ & $\mathbf{2 0 0 6}$ & $\mathbf{2 0 0 7}$ & $\mathbf{2 0 0 8}$ & $\mathbf{2 0 0 9}$ \\
\hline Area under sorghum (ha) & 122,368 & 163,865 & 155,550 & 104,041 & 173,172 \\
\hline $\begin{array}{l}\text { Production (90kg } \\
\text { bags/ha) }\end{array}$ & $1,668,081$ & $1,457,503$ & $1,63,391$ & 602,910 & $1,055,051$ \\
\hline Yields (kg/ha) & 1260 & 810 & 819 & 522 & 621 \\
\hline $\begin{array}{l}\text { National consumption } \\
\text { (90kg bags) }\end{array}$ & $1,425,000$ & $1,510,000$ & $1,551,525$ & 366,667 & 900,000 \\
\hline
\end{tabular}

Source: MOA 2010

A study done in 2008 showed that sweet sorghum is by far the best raw material, as far as cost of raw material is concerned, for bioethanol production in Kenya. This is also supported by the vast amount of land suitable for its cultivation and the short crop rotation period compared to sugarcane (MOE/GTZ 2008). It however, has some disadvantages of low sugar content and additional processing costs compared to molasses, which is currently the main raw material.

Current developments where most sugar companies are contemplating starting ethanol production will mean there will be a huge shortage of molasses for the established ethanol manufacturing plants that rely on molasses from these firms. This will force them to diversify in terms of raw materials they use and sweet sorghum is one alternative that has been floated (MOE/GTZ 2010; MOE 2009). Already, Spectre International has imported sorghum seeds from India and has been doing seed bulking to distribute to farmers when they launch ethanol production from sweet sorghum.

East African Breweries has joined in the process of sorghum promotion as they prepare to launch cheaper beer brands made of sorghum instead of barley which has to be imported. In 2010, East African Breweries distributed certified gaddam sorghum seeds to over 10,000 farmers in Eastern Province (The East African, $17^{\text {th }}$ of May, 2010). This is a unique sorghum variety that is approved for beer manufacturing

\subsubsection{Sugarcane}

Sugarcane (Saccharum spp) is a tall grass-like perennial crop that has stems referred to as canes and stores its carbohydrates in the form of sugar. It grows in the tropics and provides half of the world's sugar. In Kenya, it is mainly grown on fairly flat regions in Western, Nyanza and Coast Provinces (EPZA 2005a). Sugarcane is one of the most important crops in Kenya alongside tea, coffee, horticultural crops and maize. It directly supports 200,000 smallscale farmers who supply over $88 \%$ of the cane milled by the sugar companies (Muok et al 2010). The sugar sub-sector directly or indirectly supports about 6 million Kenyans and sugarcane farming provides direct employment to over 500,000 workers (Kenya Sugar Board 2009). It also generates about KSh 12 billion annually while domestic production of sugar saves the country in excess of KSh 20 billion in foreign exchange annually, thus playing a major economic role (KESREF 2009).

Sugarcane is used for sugar manufacture, jaggery manufacture and power/industrial alcohol manufacture. On the residues, bagasse is used in cogeneration to generate electricity while molasses is used for power/alcohol manufacture and biogas (MOE/GTZ 2008). 
Agronomy

Table 14: Agronomic parameters for sugarcane

\begin{tabular}{|l|l|l|}
\hline Agronomic parameters & Overall range & Optimal range \\
\hline Annual temp $\left({ }^{\circ} \mathrm{C}\right)$ & $12-38$ & $20-30$ \\
\hline Annual rainfall $(\mathrm{mm})$ & $1000-1800$ & $1200-1800$ \\
\hline Altitude & $0-1500$ & - \\
\hline Soil & Loam to clay soil \\
\hline Maturity & $18-24$ months (12-16 months in the coastal area) \\
\hline
\end{tabular}

Source: Muok et al 2010

Sugarcane is mostly propagated using cuttings. Each cutting must contain at least one bud. The cuttings are mostly hand-planted (Muok et al 2010). Once planted, a stand can be harvested several times since after each harvest, the cane sends up new stalks, called ratoons but yields decrease with successive harvests. For this reason, only three harvests are recommended in Kenya. A sugarcane plantation takes between 18 and 24 months to mature in Western and Nyanza Provinces while varieties planted in Coast Province take between 12 and 16 months (KESREF 2009; MOE/GTZ, 2008).

Harvesting can be done either mechanically or by hand, but the latter is mainly practised in Kenya. During harvesting, the field is first set on fire to burn dry leaves and to kill any lurking venomous snakes, without harming the stalks and roots. Harvesters then cut the cane just above ground-level using cane knives.
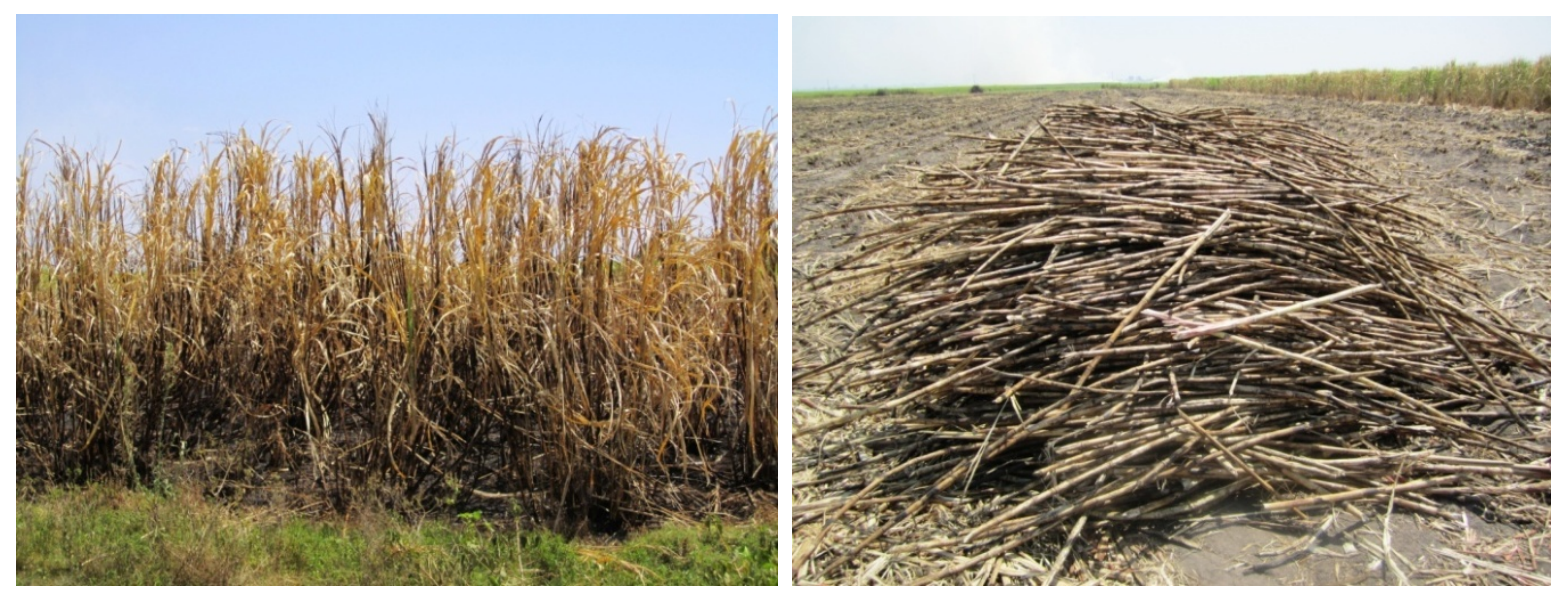

Source: Author

Fig. 12: Newly burned sugarcane ready for harvesting (left) and newly harvested cane in Kibos

Sugarcane ratoon crop can be intercropped with legumes like beans in the initial months and multipurpose trees can also be planted in contour hedgerows in non-mechanized areas (MOE/GTZ 2008).

\section{Agricultural potential and suitability}

Sugarcane farming in Kenya is concentrated in Western, Nyanza and Coast Provinces. Some parts of Eastern Province have a suitable environment for cane production but this has not been commercially exploited (Muok et al 2010). On average, a hectare of cane plantation yields between 70 and 85 tonnes of cane in the Western and Nyanza Provinces while in the 
Coast Province it averages around 100 tonnes. There is also a huge potential for irrigation in the Tana Delta which can raise the production to over 150 tonnes per hectare (KESREF 2011).

About $17,332 \mathrm{~km}^{2}$ which is equivalent to $3 \%$ of the surface area of Kenya is suitable for cane production but after zoning off wetlands, protected zones, wildlife conflict areas and slopes greater than $45 \%$, this reduces to $12,591 \mathrm{~km}^{2}$ (Muok et al 2010).

Table 15: Proportion of land suitable for sugarcane cultivation in Kenya

\begin{tabular}{|l|l|l|}
\hline Suitability and zonation & Suitability $\mathbf{a r e a} \mathbf{( k m}^{\mathbf{2}}$ & \% of land surface area \\
\hline General suitability & 17,332 & 3.0 \\
\hline Suitable outside protected area & 15,916 & 2.8 \\
\hline Suitable within food crops areas & 12,912 & 2.3 \\
\hline Suitable within cash crops areas & 1,545 & 0.3 \\
\hline Suitable outside food and cash crops areas & 1,458 & 0.3 \\
\hline Suitable within cultivated areas & 14,457 & 2.5 \\
\hline Suitable within non-cultivated areas & 1,458 & 0.3 \\
\hline Suitable outside wildlife conflict areas & 13,052 & 2.3 \\
\hline Suitable outside wetlands & 12,728 & 2.2 \\
\hline Suitable outside animal movements paths $(3 \mathrm{~km})$ & 12,591 & 2.2 \\
\hline
\end{tabular}




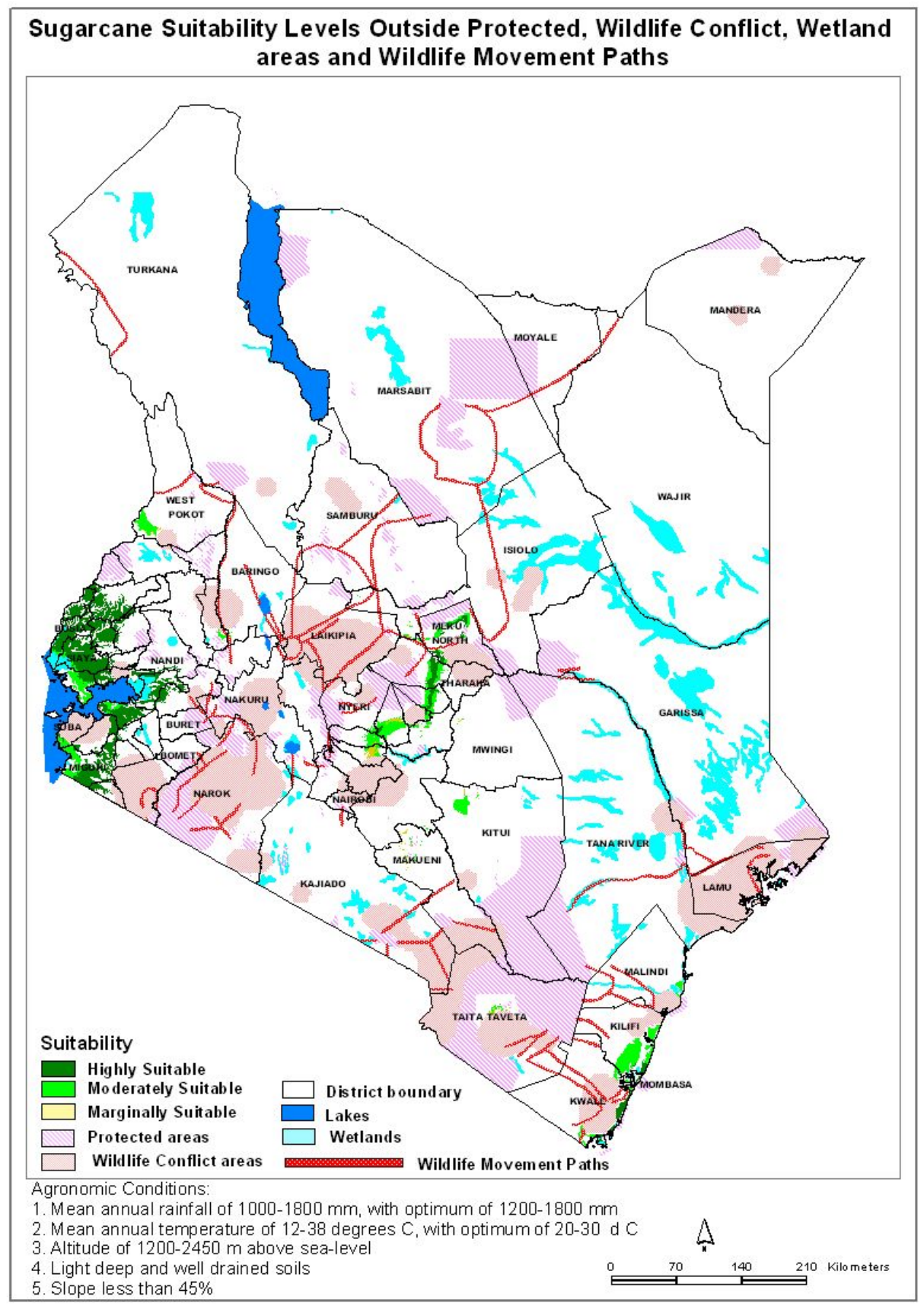

\section{Source: ICRAF GIS Unit}

Fig. 23: Sugarcane suitability zonation in Kenya

\section{Current status}

The sugar industry in Kenya has struggled for many years for various reasons, such as lack of accountability and transparency in the sector, poor management, excessive taxation and delayed payments to farmers (KESREF 2009). Sugar production technology in most factories is old and inefficient, making it among the most expensive in the continent (MOA 2010). However, the sector has impressively recovered in the last decade due to major government reforms and increase in acreage under cane (KSB 2010) 
Table 16: Sugar production 2005-2009

\begin{tabular}{|l|l|l|l|l|l|}
\hline Year & $\mathbf{2 0 0 5}$ & $\mathbf{2 0 0 6}$ & $\mathbf{2 0 0 7}$ & $\mathbf{2 0 0 8}$ & $\mathbf{2 0 0 9}$ \\
\hline Area under cane (ha) & 144,765 & 144,730 & 158,568 & 169,421 & 154,298 \\
\hline Cane production (tonnes) & $4,800,820$ & $4,932,839$ & $5,204,214$ & $5,176,670$ & $5,610,702$ \\
\hline Yields (tonnes/ha) & 84.9 & 90.3 & 87.9 & 95.0 & 85.3 \\
\hline Sugar production (tonnes) & 488,997 & 475,670 & 520,404 & 517,667 & 548,208 \\
\hline $\begin{array}{l}\text { National consumption } \\
\text { (tonnes) }\end{array}$ & 695,622 & 718,396 & 741,190 & 751,523 & 605,358 \\
\hline
\end{tabular}

Source: Kenya Sugar Board

In 2009 , the area under cane was 154,298 hectares of which $88 \%$ was owned by smallholders and the rest by nucleus estates. A study commissioned by MOE and GTZ in 2008 estimated that a tonne of sugarcane can yield 0.1 tonnes of sugar and the molasses from sugar processing, 10 litres of ethanol (MOE/GTZ, 2008) or 70 litres of ethanol if all the cane juice was used for the purpose of ethanol production. Using the same parameters, we can say that in 2009, Kenya had a capacity to produce 56 million litres of ethanol from molasses or 372.75 billion litres of ethanol if all the cane juice is used for ethanol production.
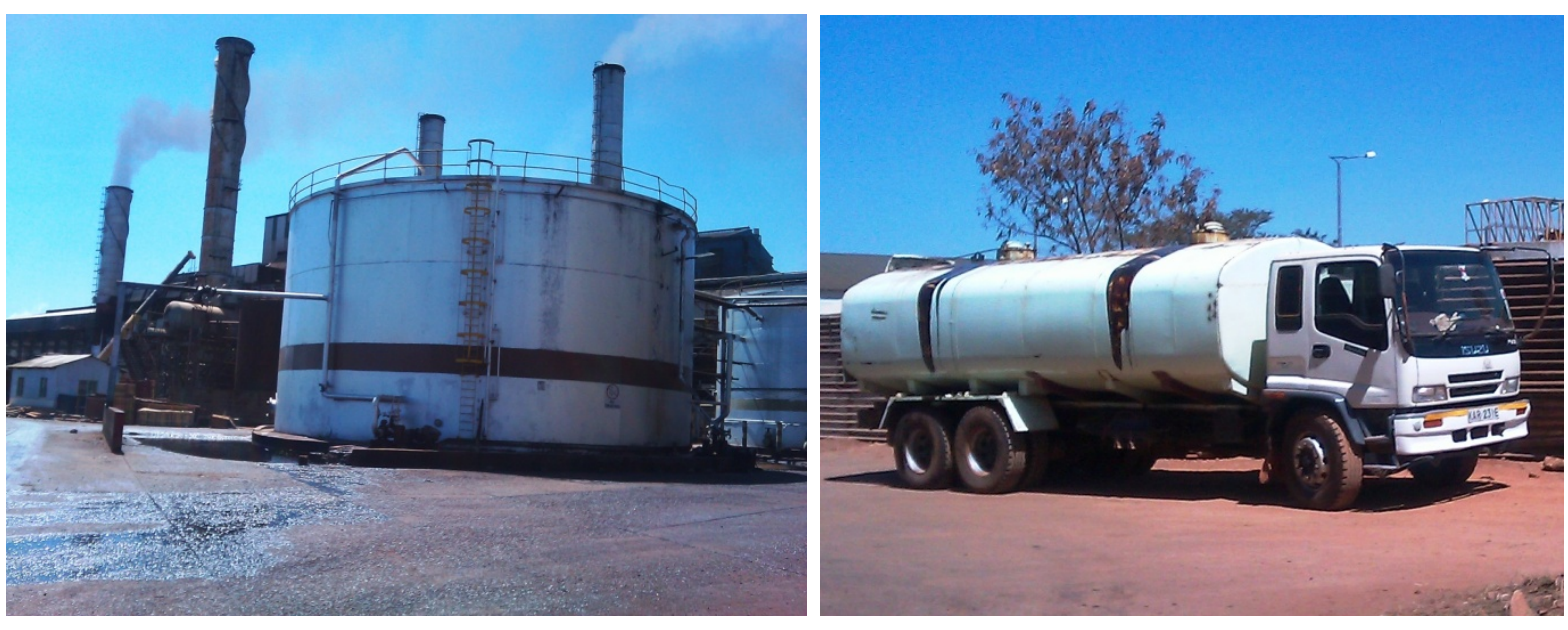

Source: Author

Fig. 14: Molasses storage tank (right) and molasses transportation tank in Mumias Sugar Company

There are currently nine operational sugar mills in Kenya with a total crushing capacity of 26,276 tonnes of sugarcane per day. The latest one is the Butali Sugar Company that began operations in January 2011.

Table 17: Current sugar mills in Kenya and their crushing capacities

\begin{tabular}{|l|l|l|l|}
\hline Sugar company & $\begin{array}{l}\text { Rated capacity } \\
\text { (t/day) }\end{array}$ & $\begin{array}{l}\text { Actual crushing } \\
\text { capacity (t/day) }\end{array}$ & Remarks \\
\hline Mumias & 8,880 & 8,048 & \\
\hline West Kenya & 2,496 & 2,417 & \\
\hline Nzoia & 3,000 & 3,147 & \\
\hline Sony Sugar & 3,240 & 2,666 & \\
\hline Kibos & 1,800 & 1,484 & \\
\hline Chemelil & 3,360 & 2,805 & \\
\hline Muhoroni & 2,400 & 2,152 & \\
\hline
\end{tabular}




\begin{tabular}{|l|l|l|l|}
\hline SOIN & 300 & 267 & \\
\hline $\begin{array}{l}\text { Butali Sugar } \\
\text { Mills }\end{array}$ & 800 & - & $\begin{array}{l}\text { Began operations in Jan } \\
2011\end{array}$ \\
\hline Total & $\mathbf{2 6 , 2 7 6}$ & - & \\
\hline
\end{tabular}

Source KESREF

There are four sugar companies expected to be built in the next three years, two of them in the coastal region, one in Transmara and one in Nyanza Province with a capacity of 15,800 tonnes per day. These would raise the total capacity of sugarcane crushing in the country to a whooping 42,076 tonnes per day.

Table 18: Upcoming sugar companies in Kenya

\begin{tabular}{|l|l|l|l|}
\hline Sugar company & Area & Expected capacity (t/d) & Remarks \\
\hline International & Kwale & 3500 & Expandable to 5,000 T/D \\
\hline Transmara Sugar & Transmara & 800 & \\
\hline Sukari & Ndhiwa & 1500 & Expandable to 2,500 T/D \\
\hline TARDA & Tana River & 10,000 & \\
\hline Total & & 15,800 & \\
\hline
\end{tabular}

Source: KESREF

Ethanol production is currently done by two companies only namely; Agro-Chemical and Food Company Limited and Spectre International Limited. Between them, they have the capacity to produce 125,000 litres of ethanol per day but produce only 57,400 litres (MOE/GTZ 2008). The capacity is expected to increase with Mumias Sugar Company currently building an ethanol plant with a capacity of 80,000 litres per day. Kwale International is also planning a 30,000-litre per day ethanol plant while most of the new companies are planning to build ethanol plants of various capacities (Daily Nation Newspaper, January 11, 2011). As such, the ethanol industry in Kenya is expected to grow rapidly in the next decade.

Table 19: Ethanol production and planned capacity

\begin{tabular}{|l|l|l|}
\hline Ethanol plant & \multicolumn{1}{|c|}{ Current production (I/d) } & $\begin{array}{l}\text { Current and planned production } \\
\text { capacity (1/d) }\end{array}$ \\
\hline Agro-Chemical & 27,400 & 60,000 \\
\hline Spectre International & 30,000 & 65,000 \\
\hline Mumias & - & 80,000 \\
\hline Kwale International & - & 30,000 \\
\hline Total & $\mathbf{5 7 , 4 0 0}$ & $\mathbf{2 3 5 , 0 0 0}$ \\
\hline
\end{tabular}

Source: MOE/GTZ 2009, KESREF

In 2003 Kenya sought COMESA intervention to protect its sugar industry from threats by cheap imported sugar from other COMESA countries by limiting imports to 200,000 tonnes per year. This later increased to 220,000 tonnes per year. The safeguards were set to expire in March 2008 but Kenya's were extended to 2012. As part of the sector reform, the government is planning to privatize all the sugar factories. They will have to be more innovative and efficient to survive the fierce competition. As such, it is projected that all of them will venture into ethanol production and cogeneration to increase their product range hence revenues. This is expected to further increase the ethanol production capacity in the country. 

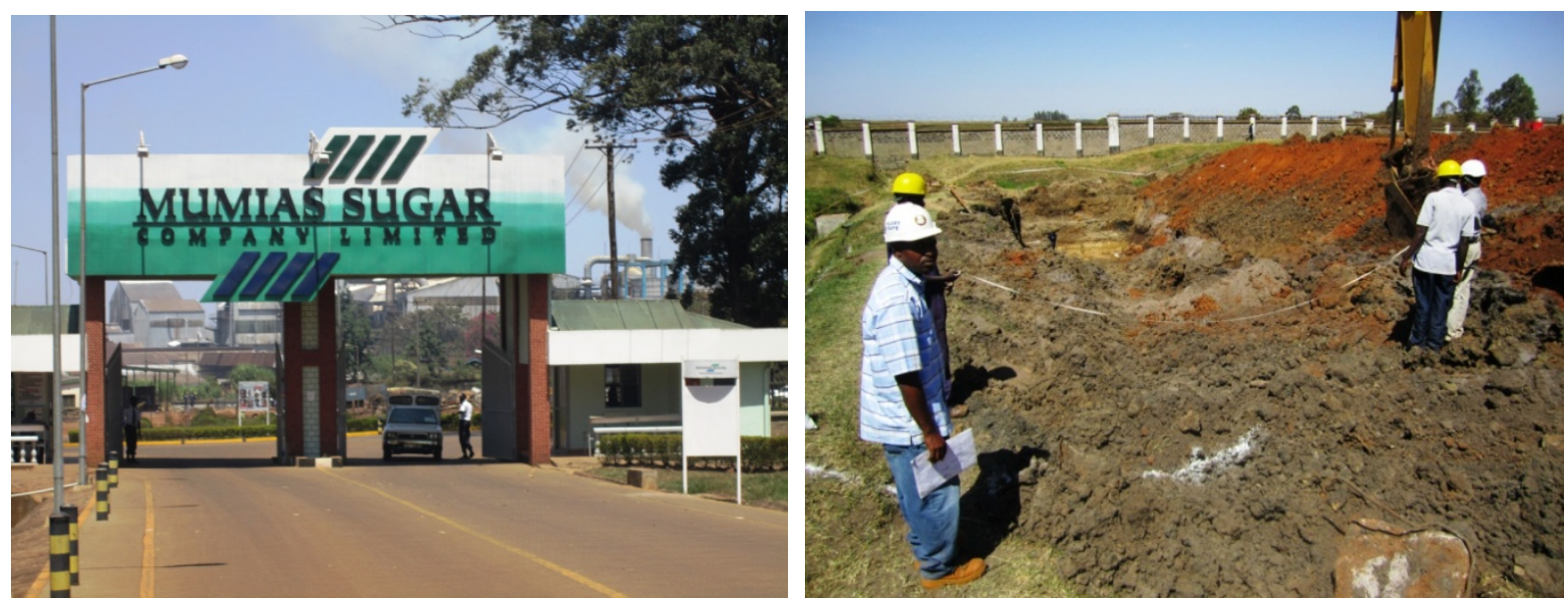

Source: Author

Fig. 15: Mumias Sugar Company entrance (left) and ongoing excavation at the proposed site for the ethanol plant (right)

\subsubsection{Cassava}

Cassava (Manihot esculenta Crantz) is a perennial woody shrub with up to $32 \%$ starch content extensively cultivated in tropical and subtropical countries. It is widely grown in East Africa especially in semi-arid areas due to its drought tolerant characteristic. In industry, it is used in the manufacture of animal feeds and starch. Starch from cassava is used as a raw material in food, textile, paper, adhesives and pharmaceutical industries.

In the coastal lowlands of Kenya, cassava is a staple food while in Western and Nyanza Provinces it is the second most important staple crop after maize (Muok et al 2010). Cultivation is mainly done by smallholder poor households for subsistence. The highest production is realized in Nyanza and Western Provinces, which produce $60 \%$ followed by Coast Province (30\%) and Eastern Province (10\%). Major constraints to cassava production include pests and diseases, poor agronomic practices, low yielding varieties, high cyanide levels, lack of clean planting materials and long maturity periods (C3P 2011). One tonne of cassava can yield between 160-180 litres of hydrous bioethanol, making it a very good crop for biofuels production.

Agronomy

Table 20: Cassava agronomic parameters

\begin{tabular}{|l|l|l|}
\hline Agronomic parameters & Overall range & Optimal range \\
\hline Annual temp $\left({ }^{\circ} \mathrm{C}\right)$ & $16-30$ & - \\
\hline Annual rainfall $(\mathrm{mm})$ & $580-1500$ & - \\
\hline Altitude & $0-1500$ & - \\
\hline Soil & Free drained rock free soils of medium fertility \\
\hline Maturity & $6-9$ months \\
\hline
\end{tabular}

Source: Muok et al 2010

Cassava is propagated vegetatively by use of stem cuttings which must have a node. They are planted at $45^{\circ}$ or laid flat in a hole about $7.5-10 \mathrm{~cm}$ deep and spacing of $0.9 \mathrm{~m}$ by $1.5 \mathrm{~m}$ for a pure stand (Muok et al 2010). Planting is done on ridges which makes harvesting easier. 
Fertilization is rarely necessary and it requires minimal maintenance (C3P 2011). The crop takes 12-24 months to mature. In the Coast Province the crop yields 5-10 t/ha compared to the $32 \mathrm{t} / \mathrm{ha}$ potential. The crop can be intercropped with other food crops like beans and other legumes, but this has not been scientifically tested (Muok et al 2010).

\section{Agricultural potential and suitability}

Under natural conditions cassava can be grown across the southern half of Kenya. Its drought tolerance means that it can survive even during the dry season where soil moisture is low but humidity is high and performs far much better than any other major food and cash crop in soils in the western, coastal and the semi-arid regions of eastern Kenya (MOE/GTZ, 2009).

According to Muok et al (2010), a total of $103,044 \mathrm{~km}^{2}$ or $18.1 \%$ of the total Kenya surface area is suitable for cassava production. However, when the protected areas, wildlife conflict areas, wetlands, slopes more than $45 \%$ and animal movement paths area zoned out, the total land available for growing cassava is $66,092 \mathrm{~km}^{2}$ or $11.6 \%$ of the total Kenya surface area.

Table 21: Proportion of land suitable for cassava cultivation in Kenya

\begin{tabular}{|l|l|l|}
\hline Suitability and zonation & Suitability area $\mathbf{( k m}^{2} \mathbf{)}$ & \%of land surface area \\
\hline General suitability & 103,044 & 18.1 \\
\hline Suitable outside protected area & 81,312 & 14.3 \\
\hline Suitable within food crops areas & 38,629 & 6.8 \\
\hline Suitable within cash crops areas & 2,141 & 0.4 \\
\hline Suitable outside food and cash crops areas & 38,754 & 6.8 \\
\hline Suitable within cultivated areas & 40,762 & 7.2 \\
\hline Suitable within non-cultivated areas & 38,754 & 6.8 \\
\hline Suitable outside wildlife conflict areas & 67,139 & 11.8 \\
\hline Suitable outside wetlands & 66,092 & 11.6 \\
\hline Suitable outside animal movements paths $(3 \mathrm{~km})$ & 63,953 & 11.2 \\
\hline
\end{tabular}

Source: Muok et al 2010

\section{Current status}

Cassava has mostly been farmed in Kenya for domestic food consumption. Industrial processing is in its infant stages with most of it done in micro-processing plants (Mbwika and Kamau 2002). The main processed products are cassava chips, dried chips, flour and starch. Cassava crisps are slowly gaining popularity in most parts of Kenya. Cassava is also used as a base in canned foods, ice cream, biscuits, confectionary and pharmaceuticals (Muok et al 2010).

Cassava production has increased steadily from 566,400 tonnes in 2005 to 911,074 in 2009, with the area under the crop also increasing from 68,320 to 70,426 hectares during that period. The yields per hectare have also been increasing with the average yields of $12.9 \mathrm{t} / \mathrm{ha}$ up from 8.0 in 2005. This has been attributed to research on better yielding and drought and pest resistant varieties spearheaded by KARI.

Table 22: Cassava production 2005-2009

\begin{tabular}{|l|l|l|l|l|l|}
\hline Year & $\mathbf{2 0 0 5}$ & $\mathbf{2 0 0 6}$ & $\mathbf{2 0 0 7}$ & $\mathbf{2 0 0 8}$ & $\mathbf{2 0 0 9}$ \\
\hline Area under (ha) & 68,320 & 68,502 & 53,610 & 54,673 & 70,426 \\
\hline Production (tonnes) & 566,400 & 656,633 & 397,705 & 750,964 & 911,074 \\
\hline Yields (tonnes/ha) & 8.0 & 9.6 & 8.7 & 13.7 & 12.9 \\
\hline
\end{tabular}




\subsection{Other potential feedstocks}

Several other feedstocks have been proposed as suitable for biofuel production in Kenya. The table below shows a list of the other feedstocks that have either not been fully adopted by farmers or their oil is currently used for much more profitable purposes.

Table 23: Other potential feedstocks

\begin{tabular}{|l|l|l|l|}
\hline Feedstock & Biofuel & Current status & Remarks \\
\hline Coconut palm & Biodiesel & $\begin{array}{l}\text { Mostly farmed in the coastal } \\
\text { region }\end{array}$ & $\begin{array}{l}\text { At current price of KSh 300 per litre for } \\
\text { coconut cooking oil, biodiesel cannot } \\
\text { compete with it }\end{array}$ \\
\hline Cotton & Biodiesel & $\begin{array}{l}\text { Grown by small-scale farmers in } \\
\text { Western, Nyanza, Central, Rift } \\
\text { Valley, Eastern and Coast } \\
\text { Provinces }\end{array}$ & $\begin{array}{l}\text { Cotton oil processing is non-existent in } \\
\text { Kenya while the amount of seeds } \\
\text { cannot support a biodiesel industry }\end{array}$ \\
\hline $\begin{array}{l}\text { Rapeseed } \\
\text { (Canola) }\end{array}$ & Biodiesel & $\begin{array}{l}\text { Grown in Western Kenya } \\
\text { Valley Province for soil } \\
\text { protection and pilot projects for } \\
\text { biodiesel in Central Province }\end{array}$ & $\begin{array}{l}\text { No current commercial use other than } \\
\text { soap manufacture. Limited acreage }\end{array}$ \\
\hline Source: Authors' compilation & $\begin{array}{l}\text { No commercial processing and quantity } \\
\text { is low to warrant biodiesel investment }\end{array}$ \\
\hline
\end{tabular}

\section{ECONOMICS OF BIOFUEL FEEDSTOCKS PRODUCTION AND COMPETING CROPS}

\subsection{Gross margins of different feedstocks and competing crops}

The cost of feedstock production largely determines the final cost of biofuels hence the viability of biofuels industry and its capacity to compete with fossil fuels. It is reported that the cost of feedstock accounts for about $65-78 \%$ of overall production expense depending on the size of the facility (Pruszko 2006).

It is therefore imperative that before a company or country embarks on producing biofuel from a particular feedstock, an economic analysis is done to ascertain the profitability and sustainably of the venture. For this reason, gross margins for the feedstocks covered above were done and this was compared with maize and beans, the most common food crops. From the suitability mapping done by the World Agroforestry Centre's GIS Unit, it was clear that biofuel feedstocks are best produced in agro-ecological zones IV to VII, which have medium to marginal agricultural use. This would eliminate potential competition with traditional food and cash crops and is also in line with the government's objective of increasing agricultural productivity in marginal and wastelands. As such, the gross margins were based on the productivity of feedstocks and food crops in these agro-ecological zones. Even though the main cash crops in Kenya are coffee and tea, the gross margins of the feedstocks were not compared with these cash crops since they perform well in agro-ecological zones I to III which should not be targeted for biofuel feedstock production. The cash crops that are prominent in agro-ecological zones IV-VII are sugarcane and cotton. Sugarcane is already covered in this report as a source for bioethanol while cotton is mentioned as a potential source of biodiesel.

The data used in this study was compiled from various sources including the Ministry of Agriculture publications (Farm Management Handbook of Kenya (2005), the Economic 
Review on Agriculture (MOA 2009 and 2010)), commissioned research papers (Jatropha; a reality check (GTZ 2009a), Assessment of Costs of Maize Production, Marketing and Processing in Kenya: A Maize Meal Value Chain Analysis (KARI 2009) and Participatory Sunflower Production, Technology Dissemination and Value Addition in Southwest Kenya (Okoko et al 2008)), among others. Interviews with key informants from KARI, KESREF, HSHC, MOE, MOA, ICRISAT, Bidco Oil Refineries, Spectre International and Mumias Sugar Company supplied important data on productivity and market prices for different crops. Interviews with farmers in Mumias yielded data on cost of production of sugarcane and income, based on payments by Mumias Sugar Company.

The cost of labour was found to vary between KSh 150 to KSh 250 per man-day from highincome areas in Central Province to impoverished areas in Eastern Province. A standard KSh 200 was applied throughout this study. Other costs taken into consideration are farm inputs (seedlings, fertilizer, equipment and pesticides) which were based on the recommended quantities at the prevailing market rates. The yields are based on the reported yields from rainfed cultivation, which is the most common practice in Kenya, from the agro-ecological zones under consideration. For castor, jatropha and croton there was no accurate data on productivity and market, thus this study relied on data estimated by GTZ (GTZ 2009a) during a research on jatropha and also on small-scale producers and processors experiences in the country.

Sweet sorghum has not been grown in Kenya as a biofuel feedstock, therefore its data was estimated from research findings by ICRISAT and Jomo Kenyatta University of Agriculture and Technology (JKUAT), two institutions that have been doing extensive research on the crop as a biofuel feedstock. The yield for sweet sorghum was also considered to be that of both seeds and stalk since the maturity of the seeds coincides with the optimal harvesting time for stalks for ethanol production.

It is possible to harvest most of the seasonal crops like maize, beans, sweet sorghum, sunflower and cotton twice a year, but this is dependent on rainfall availability which is quite erratic in the agro-ecological zones under consideration. For the purpose of this study, the seasonal gross margins of beans, sweet sorghum and sunflower were multiplied by two since it was reported that the possibility of harvesting twice a year is quite high compared to maize and cassava which were considered annual crops.

For perennial crops like sugarcane, jatropha and croton, a 10-year investment period was considered, the cash flows calculated, NPV for the period calculated and divided by 10 to get the annual NPV equivalent which was considered the annual gross margin.

In all cases, the gross margins were discounted at a $14 \%$ interest rate, which was the prevailing rate at the time of the study according to Central Bank of Kenya (CBK). All results of the analysis are presented in the appendices of this report.

From the analysis, sweet sorghum has the highest gross margin followed by sugarcane. This confirms the results of the study commissioned by MOE and GTZ (MOE/GTZ 2008) that concluded that sweet sorghum is the most suitable feedstock for bioethanol production, both in terms of suitability and profitability. It is more profitable than the competing cash crops (both sugarcane and cotton) and food crops (maize and beans). It also does not pose the problem of food security since as stated earlier; every harvest of feedstock comes with harvest of sorghum seeds which boosts food security. 
Table 24: Gross margins of selected crops used as biofuels feedstock compared to that of competing crops in Kenya

\begin{tabular}{|c|c|c|}
\hline Crop & $\begin{array}{l}\text { Gross margin } \\
\text { (KSh/ha) }\end{array}$ & Remarks \\
\hline Jatropha & $-4,423.25$ & $\begin{array}{l}\text { Negative gross margin due to lower productivity and high cost of } \\
\text { inputs }\end{array}$ \\
\hline Croton & 143.97 & Minimal positive gross margin due to low price of seeds \\
\hline Castor & -551.49 & Negative gross margin as a biodiesel feedstock \\
\hline Sugarcane & $37,746.75$ & $\begin{array}{l}\text { Positive gross margin but productivity is still too low at } 70 \text { tonnes } \\
\text { per hectare }\end{array}$ \\
\hline Sweet sorghum & 67,584 & $\begin{array}{l}\text { Has the best returns as a bioethanol feedstock and also improves } \\
\text { food security }\end{array}$ \\
\hline Sunflower & $2,921.6$ & $\begin{array}{l}\text { Has a positive gross margin but is mostly used as a source of } \\
\text { edible oil providing completion for food }\end{array}$ \\
\hline Cassava & 20,240 & $\begin{array}{l}\text { Has a positive gross margin but is a source of livelihood for the } \\
\text { resident of the arid and semi-arid areas }\end{array}$ \\
\hline Maize & 3,784 & Positive gross margin \\
\hline Beans & 18,304 & Positive gross margin \\
\hline Cotton & $-14,912.48$ & $\begin{array}{l}\text { Cotton farmers have been making losses due to the volatile nature } \\
\text { of the international market }\end{array}$ \\
\hline
\end{tabular}

Source: Authors' calculation

Jatropha is not profitable as a feedstock, mainly due to its low income, low productivity and high cost of inputs. This is in line with the GTZ study of 2009 (GTZ 2009a) which also concluded that in Kenya, jatropha cultivation is not profitable for Kenyan farmers unless it is planted as a fence or hedge, in which case it requires minimum attention. The same study concluded that croton as a feedstock is not profitable unless it is planted as a fence, or for wood supply. During the time of that study, HSHC, the only organization currently buying croton seeds for small-scale biodiesel production, was paying farmers KSh 5 per $\mathrm{kg}$ of seeds but the organization has since then increased the figure to KSh 6 which now sees a farmer realize minimal profit.

Castor as a biodiesel feedstock is not profitable due to the low rates that would have to be paid for the final product to be able to compete with fossil diesel. As mentioned earlier, KIRDI had come up with the argument that castor oil is much too valuable for other industrial uses and since Kenya is a net importer of the oil, its farming should be promoted not as a biodiesel feedstock, but for industrial utilization which could fetch farmers higher returns.

Cassava has been used in some countries as a feedstock for bioethanol production and its gross margin at over KSh 20,000 per hectare support the investment in Kenya. However, such an initiative needs to be carefully evaluated since the crop is seen as a source of livelihood for the poor in the arid and semi-arid areas of the country.

Sugarcane has been used for ethanol production in Kenya mainly from molasses and the positive gross margins at almost KSh 38,000 per hectare support its continued use. 


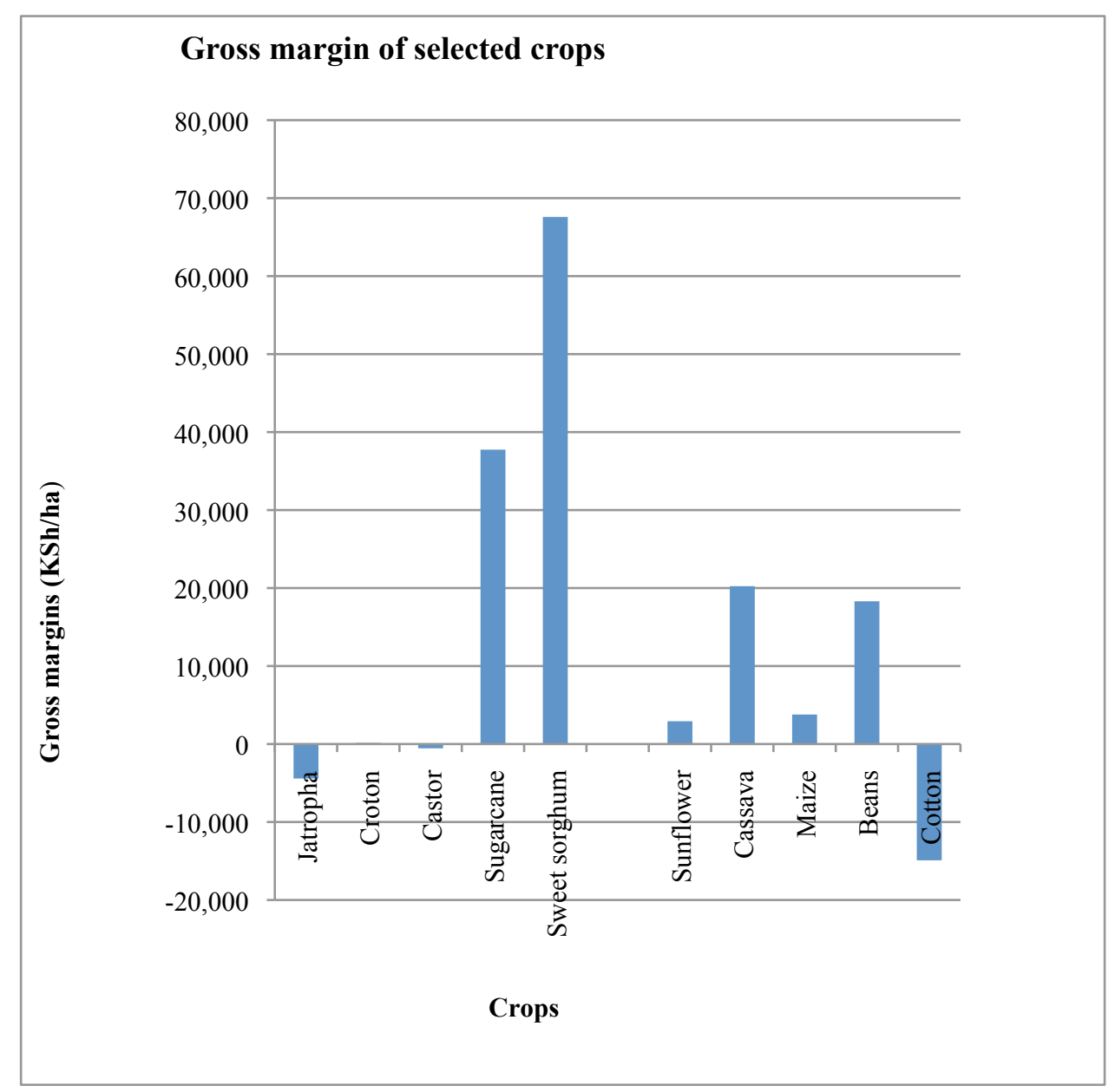

Source: Author

Fig. 16: Gross margins of selected crops

\subsection{The way forward}

The biofuel sector in Kenya has a huge potential with bioethanol expected to play a bigger role than biodiesel. The gross margins clearly show that the country is better off promoting sweet sorghum for bioethanol production, not only because it is more profitable, but also because it enhances food security. Sugarcane is expected to play a major role in bioethanol supply, and with COMESA safeguards nearing expiry, production of ethanol will give the sugar industries a chance to diversify and increase their revenues, hence becoming more economically sound.

In 2009, Kenya consumed a total of 0.46 million tonnes or 633 million litres of petrol (KNBS 2010) of which $10 \%$ or 63.3 million litres will have to be displaced by ethanol when the blending directive comes into effect. According to ICRISAT, a tonne of sweet sorghum stalks can produce about 40 litres of ethanol, while a hectare of land produces about 35 tonnes of stalks (Mgonja 2011). This translates to 1400 litres of ethanol per hectare of sweet sorghum. If Kenya hopes to supply all the ethanol for blending from sweet sorghum, about 45,000 hectares of sweet sorghum would be required and this in turn would yield 66,000 tonnes of sorghum for consumption. 
For sugarcane, if the current trend continues of producing ethanol from molasses, one tonne of sugarcane produces 0.1 tonnes of molasses which in turn produces 10 litres of ethanol. With one hectare of sugarcane plantation yielding about 70 tonnes of cane, which translates to 700 litres of ethanol, a total of about 90,000 hectares would therefore be required to produce ethanol from molasses to cover the E10 blend. Kenya is currently producing 57,400 litres on ethanol per day and so if production took place every day of the year total production would amount to 21 million litres only. This is only a third of the national E10 blending programme requirement. However, with the planned and current capacity projected to rise to 235,000 litres per day in the future which would translate to 86 million litres if production takes place everyday, Kenya will have the capacity to cater for all her bioethanol requirements.

Table 25: Land requirement to meet the E10 demand from sweet sorghum and sugarcane

\begin{tabular}{|l|l|l|l|l|}
\hline Crop & $\begin{array}{l}\text { Yield } \\
\text { (t/ha) }\end{array}$ & $\begin{array}{l}\text { Bioethanol } \\
\text { yield (l/tonne) }\end{array}$ & $\begin{array}{l}\text { Bioethanol yield } \\
(\mathbf{l} / \mathbf{h a})\end{array}$ & $\begin{array}{l}\text { Land requirement to meet E10 } \\
\text { blending (63.3 million litres) in ha }\end{array}$ \\
\hline Sweet sorghum & 35 & 40 & 1,400 & 45,000 \\
\hline Sugarcane & 70 & 10 (molasses) & 700 & 90,000 \\
\hline
\end{tabular}

Source: Authors' estimation

In 2009, Kenya consumed 1.46 million tonnes or 1.72 billion litres of diesel. With a B2 blending (later to be rolled out to B5) as recommended in a study commissioned by MOE and GTZ (MOE/GTZ 2008) about 35 million litres of biodiesel would be required. However, with the main biodiesel crops promoted being croton and jatropha whose productivity is quite low and their cultivation not fully understood, it is difficult to estimate the requirements in terms of land or processing capacity.

Based on rough estimates by GTZ, a tonne of jatropha seeds produces 336 litres of biodiesel. At an average yield of 2.5 tonnes of seeds per hectare for rain fed cultivation (MOE/GTZ 2008), over 102,000 hectares of land would be required for a B2 blending and about 260,000 hectares for a B5 blend. From the same study, croton has similar biodiesel yields per tonne and seed yields per hectare which translates to approximately the same land requirement. This is a sobering reality the government will have to take into consideration before plunging into B2 and later rolling it out to B5 blending because it can lead to either massive competition with other land uses to satisfy demand or collapse due to lack of feedstock.

\section{NATIONAL BIOFUEL STRATEGIES, POLICIES AND REGULATIONS}

\subsection{Existing national policies and legislations that have an impact on the biofuels sector}

Policy interventions and strategies greatly shape the biofuels sector in any country by setting objectives that help in improving energy access, ensure security of supply of affordable energy and achieve efficiency and conservation (FAO/GBEP 2007). Several countries especially in the European Union have implemented policies that have seen their biofuel sector flourish and play an important role in the country's development. For the biofuel sector to flourish in Kenya, the right legal and policy framework needs to be in place. This section analyses the existing and draft policies and legislations that impact on the biofuels sector in Kenya.

Sessional Paper No. 4 was the first major energy framework policy which developed specific sectoral or sub-sectoral energy policies aimed at encouraging wider adoption of renewable energy technologies in Kenya. The policy recognizes the potential for production of biofuel 
from locally grown crops, and in order to utilize biodiesel, observes that a system for production, distribution and use will need to be put in place (KIPPRA 2010). The policy recognizes the need to set aside land for the production of energy crops, formulate strategies to optimize land use and to harmonize the existing land use policy with the energy policy (GOK 2004). It also calls for resources to be mobilized for research and development that will facilitate introduction of biofuels as a motor fuel blend in the medium term.

The Energy Act 2006 which became operational in July 2007 mandates the government to pursue and facilitate the production of biofuels. It does not give much detail on how this is to be achieved but it authorizes the government to adopt a biofuels policy to promote the use of biofuels in the country (Muok et al 2008). However this has not happened to date although the policy has been drafted and is awaiting adoption. The Energy Act is also unclear whether it is permissible to produce, sell or use biofuels in the absence of clear standards from the Kenya Bureau of Standards (MOE/GTZ 2008). The Energy Act also directs that KEBS determines fuel quality and blending standards for biofuels.

The Environmental Management and Coordination Act 1999 (EMCA) and the Environmental (Impact Assessment and Audit) Regulation 2003 ("Regulations") provides a framework for coordinated management of environment and development matters. This framework provides instruments and tools for assessing proposed development activities to ensure they are economically viable, socially acceptable and environmentally sound. The EMCA requires that KEBS conduct an environmental impact assessment (EIA) analyzing the environmental impact of any biofuels standards it proposes. It also requires that EIA be performed by the National Environment Management Authority (NEMA) for any biofuels project, programme or policy that may have an impact on the environment. An Environmental Impact Assessment License (EIAL) is then issued before the project can be started.

Research has shown that most of the land considered arid and semi-arid is suitable for biofuels feedstock production. However, the policy on arid and semi-arid lands (ASALs) indicates that this opportunity for investment has not been utilized (GOK 2005). Biofuel production initiatives can be mainstreamed in the ASALs with a view to achieving the objectives of the strategy of increasing agricultural investments in the area and the economic wellbeing of the people.

The Agriculture Act (Cap 318) provides for the conservation of soil and its fertility, and the development of agricultural land in accordance with accepted practices of good land management and good husbandry. The Strategy for Revitalizing Agriculture 2004-2014 focuses on agriculture as a key sector for growth and employment, and discusses in detail the need for increased support to agro-processing industries in rural areas and improved linkages between producers, suppliers, processors and market. It also recognizes the importance of new and emerging crops including biofuel feedstocks. The country's Vision 2030 aims at industrializing the agricultural sector through enhanced agro-processing and value addition to crops.

Government Lands Act (Cap 280), the Registration of Titles Act (Cap 281), the Land Titles Act (Cap 282), Registered Land Act (Cap 300), Trust Land Act (Cap 288), the Indian Transfer of Property Act and the Sectional Properties Act, all deal with issues concerning land tenure which is an important component of adopting biofuels in Kenya. They give directives on the terms and conditions under which rights to land and land-based resources are acquired, held, used, disposed and transferred or transmitted to another party. 
The Forest Act 2005 provides for the conservation of Kenya's forest resources and their rational utilization for the socio-economic development of the country. Section 8 of the act requires all indigenous forests and woodlands to be managed on a sustainable basis for the conservation of water, soil and biodiversity, riverbank and shoreline protection, and the sustainable production of wood and non-wood products. This act cannot be ignored especially where the feedstock is from woody biomass like jatropha and croton.

The most recent developments in terms of legislations related to biofuels include drafting of both the biodiesel (Strategy for Developing the Bio-Diesel Industry in Kenya; 2008-2012) and bioethanol (Bioethanol Strategy 2009-2012) strategies and drafting of the biofuels policy (Proposed National Biofuel Policy 2010). These pieces of legislation are supposed to promote biofuels production and use as well as act as a legal framework within which the sector will operate. The drafting has been facilitated by the Ministry of Energy by calling together all the stakeholders and line ministries to give their input. However, all remain drafts but the stakeholders and the public as a whole hope that they will be adopted soon to help move the sector forward.

\subsection{Regional and international commitments impacting on biofuels}

Kenya is a member of international community and has entered into several international agreements which would have an impact on any biofuels investment. Regionally, Kenya is a member of Common Market for Eastern and Southern Africa (COMESA) a regional economic bloc of 19 countries that requires free movement of goods and services between the member countries. Under COMESA all the member states are supposed to abolish all nontariff barriers to trade amongst themselves and establish a common external tariff. The member states are also supposed to adopt common standards, measurement systems and quality assurance practices in respect of goods produced and traded within the Common Market.

Internationally, Kenya is a signatory to the UNFCCC and has ratified the Kyoto Protocol which was adopted in 1997 and came into force in 2005. However, it is not obliged to reduce its greenhouse gas emissions but use of biofuels would contribute to the goals of this convention. The Kyoto Protocol allows for several mechanisms, such as emissions trading and the Clean Development Mechanisms (CDM), to allow industrialized countries meet their reduction targets by either purchasing emission reduction credits from elsewhere within the industrialized world, or through projects that reduce emissions in developing countries. Biofuel projects in Kenya would benefit from such mechanisms.

The Convention on Biological Diversity (CBD) establishes a global legally binding framework for the conservation of biodiversity, the sustainable use of its components, and the fair and equitable sharing of benefits arising out of utilization of genetic resources. Any biofuel project needs to abide by its requirements of conservation of various species of indigenous plants, animals and variety of ecosystems in the project area. Kenya has also ratified the Convention on Wetlands of International Importance (the Ramsar Convention) where the parties are required to promote wise use of wetlands in their territories and to take measures for their conservation by establishing nature reserves in wetlands. Any investments in biofuel feedstocks production in such areas need to be in conformity with the provisions of this convention. 


\section{CERTIFICATION SCHEMES AND STANDARDS FOR BIOFUELS OR THEIR FEEDSTOCK}

Biofuels are relatively new fuels in most countries and Kenya is no exception, rendering them more uncertain regarding their performance than conventional gasoline and diesel. To safeguard against these uncertainties, many countries have drafted standards giving the minimum specifications that the biofuels must meet, while those who don't have, have adopted from other countries like USA and Germany which are already far much ahead in this field (IEA 2009). The minimum test requirements for biodiesel blend extenders are specified in ASTM D6751 in USA and EN 14214 within Europe. On top of the quality standards, the Energy Act 2006 explicitly directs that; "a person engaged in petroleum business shall comply with the relevant Kenya Standard and in the absence of such standard, any other standard approved by the Commission from time to time on environment, health and safety in consultation with the relevant authorities and in conformity with the relevant statutes touching on environment, health and safety standards." It is therefore imperative that anybody engaged in biofuels would also be subject to these directives to ensure safety to the people and the environment.

\subsection{Existing biofuels standards}

\subsubsection{Draft biodiesel standards}

Though biodiesel is yet to be commercialized in Kenya, the government and stakeholders anticipate this will happen in the future. In this regard, KEBS, the body mandated to design standards in Kenya, together with the Ministry of Energy and other stakeholders in the energy sector drafted biodiesel standards that are contained in article KS 2227:2010 of KEBS. These standards, though still in draft form, give the minimum requirements that biodiesel should meet before being availed into the market in terms of chemical composition, physical properties and safety parameters as shown in Table 26.

Table 26: Physical and chemical composition of biodiesel

\begin{tabular}{|c|c|c|}
\hline Property & Requirement & Test method \\
\hline Sulphated ash content & 0.02 & ISO 3987 \\
\hline \multicolumn{3}{|l|}{ Alkaline content } \\
\hline Free glycerol content $\%$ mass fraction, $\max$ & 0.02 & EN 14105, 14106 \\
\hline Copper stripe corrosion $\left(3 \mathrm{~h}\right.$ at $\left.50{ }^{\circ} \mathrm{C}\right)$ rating, $\max$ & Class 1 & ISO 2160 \\
\hline Methanol and ethanol content & 0.2 & EN 14110 \\
\hline Acidic number mg KOH/g, max & 0.5 & EN 14104 \\
\hline Total glycerol content $\%$ mass fraction & 0.25 & EN 14105 \\
\hline Phosphorous content $\mathrm{mg} / \mathrm{kg}, \max$ & 10 & EM14107 \\
\hline Carbon residue on $10 \%$ distillation residue) & 0.3 & ISO 10370 \\
\hline Ester content (\% mass fraction, $\min )$ & 96.5 & EN14103 \\
\hline \multicolumn{3}{|l|}{ Distillation temperature } \\
\hline Flash point $0 \mathrm{C}, \min$ & 120 & ISO 3104 \\
\hline Total contamination $\mathrm{mg} / \mathrm{kg}, \max$ & 24 & EN 12662 \\
\hline Sulphur content $\mathrm{mg} / \mathrm{kg}, \max$ & 10 & ISO 20846, ISO 0884 \\
\hline Cold climate operability & 6 & EN 116 \\
\hline Cetane number, $\min$ & 51 & ISO 5165 \\
\hline Oxidation stability at $110^{\circ} \mathrm{C}, \mathrm{h}, \mathrm{min}$ & 6 & EN14112 \\
\hline Mono, di, tri, acylglycerides & $\begin{array}{l}0.8,0.2,0.2 \\
\text { respectively }\end{array}$ & EN 14105 \\
\hline
\end{tabular}




\begin{tabular}{|l|l|l|} 
Density at $20^{\circ} \mathrm{C}, \mathrm{kg} / \mathrm{m}^{3}$ & $860-900$ & ISO 3675, ISO 12185 \\
\hline Kinetic viscosity at $40^{\circ} \mathrm{C}, \mathrm{kg} / \mathrm{m}^{3}$ & $3.5-5.0$ & ISO 3104 \\
\hline Water content and sediment \%mass fraction & 0.05 & ISO 12937 \\
\hline Iodine number g of iodine $/ 100 \mathrm{~g}$ of FAME & 140 & EN 14111 \\
\hline Linoleic acid content & 12 & EN 14103 \\
\hline Polyunsaturated methyl ester & 1 & \\
\hline
\end{tabular}

Source: KEBS 2010

\subsubsection{Bioethanol standards}

The bioethanol draft KS 382:1982 was prepared by the fuel technical committee on petroleum products. It was distributed on $4^{\text {th }}$ February 2010 for public review in preparation for revision. The table below shows the requirements for bioethanol standards that are yet to be revised.

Table 25: Physical and chemical composition of bioethanol

\begin{tabular}{|l|l|}
\hline Property & Requirement \\
\hline Colour & Colourless \\
\hline Appearance & Clear \\
\hline Density at $15^{0} \mathrm{C}$, max & 0.7961 \\
\hline Sulphate content & \\
\hline Total sulphur content by mass, max & 0.2 \\
\hline \multicolumn{1}{|c|}{ copper content 3 h at $50^{0} \mathrm{C}$} & Class 1 \\
\hline iron content & \\
\hline \multicolumn{1}{|c|}{ sodium content } & \\
\hline Electrolyte conductivity & \\
\hline Ethanol content \% by vol at $15^{0} \mathrm{C}, \min$ & 99.5 \\
\hline Acidity as acetic acid \% by mass, max & 0,006 \\
\hline Phosphorous content & \\
\hline Ph & \\
\hline Gum/residue evaporation & 0.005 \\
\hline Chloride content & \\
\hline Water content \% by volume, max & 0.5 \\
\hline Sourc: KEBS, 1990
\end{tabular}

Source: KEBS, 1990

\section{NATIONAL LIQUID TRANSPORT FUELS MARKET}

\subsection{Major transport fuels consumed in Kenya}

The transport sector which includes land, water and air transport is the largest consumer of petroleum fuels accounting for about $70 \%$ of petroleum fuel consumption in the country. Diesel (automotive gas oil) is the leading petroleum product consumed in the country because it is a dual purpose fuel consumed by transport and agriculture. It had a six-fold rise between 2003 and 2008 (KIPPRA 2010). On the other hand, petrol (motor spirit) which is mostly used in the transport of passengers and goods has not had remarkable growth due to the high efficiency of the vehicles entering the domestic market, in spite of the rise in numbers (KNBS 2010). Illuminating kerosene is the fuel of choice for many rural and informal urban settlements in Kenya which don't have access to electricity. Its consumption has remained almost constant over the years despite increase in population owing to the rolling out of rural 
electrification programmes which has seen many rural areas get connected to the electric grid and adoption of solar for lighting.

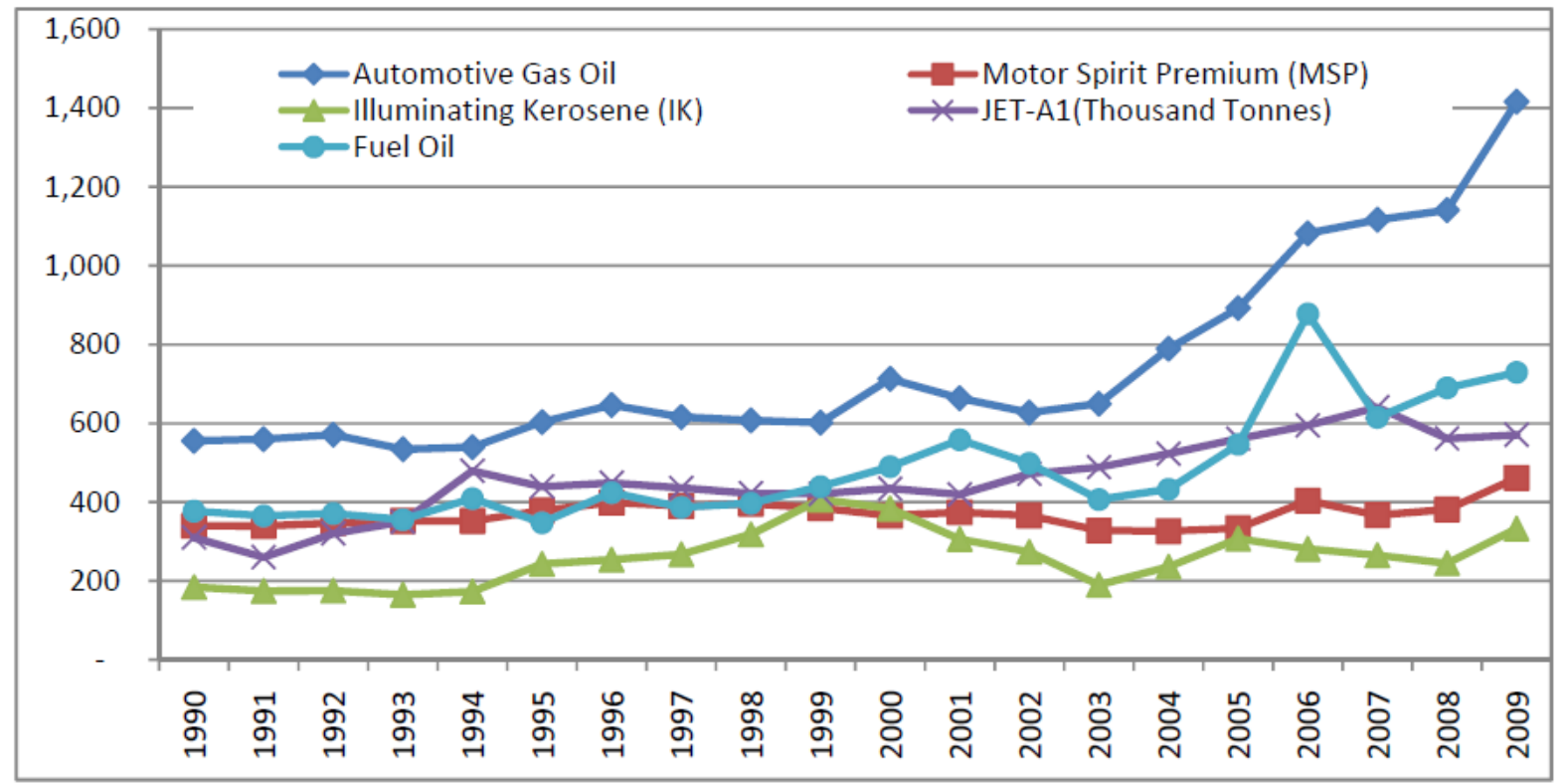

Source: KIPPRA, 2010

Fig. 17: Consumption of selected petroleum products (000s tonnes)

In 2009, over 3.61 million tonnes of petroleum fuels were consumed in the country with about $57 \%$ of it being sold at retail pump outlets and for road transport. Of this total, 1.46 million tonnes was diesel and 0.46 million tonnes motor spirit (KNBS 2010). This is the amount of fuel that is targeted for blending with liquid biofuels. With the recommended E10 blending, 46,000 tonnes of bioethanol would be required per annum. A study commissioned by MOE and GTZ (GTZ/MOE 2010) recommended a $2 \%$ blend of biodiesel with $98 \%$ of diesel as a starting point for Kenya's biodiesel blending programme. This would require about 29,200 tonnes of biodiesel per annum. Another potential use of biodiesel is illumination, displacing kerosene. Displacing a quarter of the illuminating kerosene used in 2009 would require about 83,200 tonnes of biodiesel which is even more than that for blending.

Table 27: Selected petroleum fuels consumption in Kenya from 2005-2009

\begin{tabular}{|l|l|l|l|l|l|}
\hline \multirow{2}{*}{ Fuel type } & \multicolumn{4}{l|}{ Consumption in '000 tonnes } \\
\cline { 2 - 6 } & $\mathbf{2 0 0 5}$ & $\mathbf{2 0 0 6}$ & $\mathbf{2 0 0 7}$ & $\mathbf{2 0 0 8}$ & $\mathbf{2 0 0 9}$ \\
\hline Motor spirit & 333.7 & 358.2 & 367.1 & 381.3 & 461.7 \\
\hline Illuminating kerosene & 307.0 & 279.2 & 265.2 & 244.7 & 332.8 \\
\hline Light diesel & 892.4 & $1,035.6$ & $1,116.5$ & $1,141.1$ & $1,416.1$ \\
\hline
\end{tabular}




\subsection{Price evolution of fuels consumed in Kenya}

Table 28: Evolution of selected fuel prices in Kenya

\begin{tabular}{|l|l|l|l|l|l|l|l|l|l|l|}
\hline Year & $\mathbf{1 9 9 1}$ & $\mathbf{1 9 9 3}$ & $\mathbf{1 9 9 5}$ & $\mathbf{1 9 9 8}$ & $\mathbf{2 0 0 0}$ & $\mathbf{2 0 0 2}$ & $\mathbf{2 0 0 4}$ & $\mathbf{2 0 0 6}$ & $\mathbf{2 0 0 8}$ & $\mathbf{2 0 1 0}$ \\
\hline $\begin{array}{l}\text { Motor spirit price } \\
\text { (US cents/L) }\end{array}$ & 53 & 40 & 56 & 70 & 71 & 70 & 92 & 112 & 120 & $109^{*}$ \\
\hline $\begin{array}{l}\text { Diesel price (US } \\
\text { cents /L) }\end{array}$ & 37 & 33 & 43 & 54 & 60 & 56 & 76 & 98 & 114 & $96^{*}$ \\
\hline
\end{tabular}

*July 2010 prices

Source: GTZ, 2009b and KNBS, 2010b

Fuel prices have been progressively increasing over the years from 53 US cents/litre and 37 US cents/litre for petrol and diesel respectively in 1991 to a high of 120 US cents/litre and 114 US cents/litre in 2008. In 2009 there was a sharp decline in prices of petroleum products as a result of the world financial crisis and the international fall in demand for crude oil (KNBS 2010a). The upward trend however continued in 2010 with economic recovery and the Kenyan government felt that the oil marketers were exploiting the public.

In 2010, the government legislated The Energy (Petroleum Pricing) Regulations 2010 which set out to regulate the maximum wholesale and retail prices in accordance with the following formulae:

(a) Wholesale Prices

For super petrol, regular petrol, kerosene or automotive diesel;

$\mathrm{P}_{w}=\mathrm{C}_{u}\left(1+\mathrm{L}_{p}+\mathrm{L}_{d}\right)+\mathrm{K}\left(1+\mathrm{L}_{d}\right)+\mathrm{m}_{w}$

Where:

$\mathrm{P}_{w}=$ the maximum wholesale price for super petrol, regular petrol, kerosene or automotive diesel;

$\mathrm{C}_{u}=$ the weighted average cost in shillings per litre ex the Kenya Petroleum Refineries Limited (KPRL) and ex Kipevu Oil Storage Facility (KOSF);

$\mathrm{K}=$ the transportation cost from Mombasa to the nearest wholesale depot, which is made up of $x$ percent of pipeline tariff $\left(\mathrm{K}_{p t}\right)$ and $(100-x)$ percent of road bridging cost $\left(\mathrm{K}_{r d}\right)$.

$\mathrm{L}_{p}=$ the allowed losses in the pipeline;

$\mathrm{L}_{d}=$ the allowed losses in the depot;

$\mathrm{m}_{w}=$ the allowed oil marketing company's gross wholesale margin.

(b) Retail Pump Prices for super petrol, regular petrol, kerosene or automotive diesel;

$\mathrm{P}_{r}=\mathrm{P}_{w}+\mathrm{m}_{r}+z$

Where, 
$\mathrm{P}_{r}=$ the maximum retail pump price of super petrol, regular petrol, kerosene or automotive diesel applicable, in shillings per litre;

$\mathrm{m}_{r}=$ the allowed maximum retail gross margin;

$z=$ the delivery rate from the nearest wholesale depot to a retail dispensing site in shillings per litre.

Under these rules, those found selling petroleum products above the maximum levels are liable to a fine of KSh $1,000,000$ or withdrawal of their operating license or both. The maximum prices are determined every 15 th day of the month and come into force until the 14th day of the following month.

\subsection{Fossil fuels displacement targets}

Many countries in the world have set biofuels mandates in order to support their biofuels sector and also to meet GHG emissions target for those required to do so under the Kyoto Protocol. In Kenya, all automotive spirit should be blended with $10 \%$ bioethanol which would end up displacing $10 \%$ of the petrol consumed in the country. This has however not been implemented, though it has already been gazette. According to the Ministry of Energy it will come into force around March 2011. If this happens, going by the 2009 automotive oil consumption figures, the demand for bioethanol would stand at 46,000 tonnes per annum.

For biodiesel, no mandates have been legislated to date though the Draft Biodiesel Licensing Regulations, 2009, and the Draft Strategy for Developing the Biodiesel Industry in Kenya, 2008-2012 (MOE 2008) set the mandate at B5 (5\% biodiesel and 95\% diesel) by the year 2012. However, a previous research commissioned by MOE and GTZ had recommended a B2 mandate (MOE/GTZ 2008), commensurate with the available capacity for Kenya to produce all the biodiesel locally.

\section{CONCLUSIONS AND RECOMMENDATIONS}

This study sought to ascertain the national potential of producing enough biofuel feedstock for both local consumption and export in Kenya. To this end the following conclusions can be made.

\section{Bioethanol}

- In terms of suitability, sweet sorghum is the most suitable bioethanol feedstock at $185,822 \mathrm{~km}^{2}$ of the country surface area. This is followed by cassava and sugarcane at $66,092 \mathrm{~km}^{2}$ and $12,591 \mathrm{~km}^{2}$ respectively.

- Production of bioethanol from sweet sorghum enhances food security because with every harvest of sweet sorghum stalks for ethanol production, sorghum seeds for human consumption are produced.

- Production of bioethanol from sweet sorghum is the most profitable with a gross margin of over KSh67,000 per hectare.

- $\quad$ Based on the 2009 petrol consumption levels, Kenya would require 46,000 tonnes or 63.3 million litres of bioethanol to implement the E10 blending programme which would require about 45,000 hectares of sweet sorghum plantation. If all the bioethanol were to be produced from sugar molasses, then this would require about 90,000 hectares of sugarcane plantation. 
- The technology to produce bioethanol already exists in the country, the programme having begun in the early 1980s. Already, two companies are producing ethanol and others are planning to commence operations in the next few years.

- Kenya currently produces 57,400 litres of ethanol per day, which would translate to about 21 million litres per annum. This would cover about a third of the amount required to implement the E10 blending programme. However, the planned and current capacity totals 235,000 litres of ethanol per day which translates to about 81 million litres per annum. This is more than the amount required for the E10 programme hence there will be some left over for export.

- Kenya has had bioethanol standards which were formulated for the blending programme in early 1980s. However, these have been revised to reflect the current regional and international requirements where necessary but they are still in draft form.

- There are national and international legislations and commitments to govern production of bioethanol feedstocks and fuel in order to ensure safety to the environment and consumers.

\section{Biodiesel}

- Based on environmental suitability, castor has the largest suitable area in Kenya at $159,115 \mathrm{~km}^{2}$ and is closely followed by jatropha at $149,302 \mathrm{~km}^{2}$. However, since both crops have not been fully domesticated and little data exists on their cultivation and management in Kenya, this information is based on estimation and in reference to where the crops have been found growing freely in the wild.

- There is no commercial production of any biodiesel feedstock in Kenya for biofuel purposes.

- Considering the current productivity levels of the feedstocks under review, only sunflower has significant positive returns while croton has marginal returns. Jatropha and castor have negative gross margins making them unsuitable for cultivation as biofuel feedstock. However, sunflower is an edible oil crop and diverting it to biodiesel production would lead to a serious food problem.

- Although castor oil can be used to make biodiesel, it has many other industrial uses that would fetch farmers much more revenue, hence should not be promoted as a biofuel crop.

- There is no established commercial biodiesel production in the country, with only one known self-help group buying croton seeds from farmers who collect them from the neighbourhoods and the forest.

- The technology to make biodiesel is available in Kenya. KIRDI has done extensive research in the field but there are no local equipment producers hence everything has to be imported.

- A national B2 blending programme which was recommended in the Biofuels Roadmap (MOE/GTZ 2008), requires 35 million litres (based on national 2009 diesel consumption) of biodiesel, which at the current rate of productivity of jatropha and croton, would require 102,000 hectares of land for plantation establishment. If the B2 programme is rolled out later as suggested, it would require about 260,000 hectares of land. 
- Biodiesel standards have been drafted by KEBS in readiness for the anticipated blending programme.

- There exists national and international legislations and commitments to govern production of biodiesel feedstocks and fuel in order to ensure safety to the environment and consumers.

\section{Recommendations}

Based on this study, the following recommendations can be made to ensure a sustainable biofuel sector in Kenya in terms of production and consumption:

- On ethanol production, the country does not have the capacity to support an E10 blending programme, but this will change in the near future. Thus, this initiative should be pursued in line with capacity expansion.

- More research should be done on sweet sorghum as a biofuel feedstock due to its dual benefit of enhancing food security and economic benefits to the farmers.

- Incorporating food-based crops like cassava and sunflower in biofuels production could have a negative impact on food security in the country, therefore should be discouraged.

- More research should be done to develop better biodiesel feedstock varieties, especially jatropha and croton, and improve their productivity if the crops are to have a significant contribution in biofuels supply and economic development for the farmers.

- The biofuels policy needs to be adopted so as to give the sector a legal framework within which to operate.

- Small scale pilot biodiesel production units needs to be established in rural areas that already have biodiesel feedstocks to act as demonstration sites and as markets for the local farmers.

- Use of biodiesel in rural areas not connected to the grid to generate power for water pumping, lightning and for use by SMEs like posho mills should be encouraged to promote rural development.

- Biofuels produced should be for local consumption and not export unless there is surplus since there is a big local market. 


\section{REFERENCES}

- Abbott J.C. and Makeham J.P. (1979) Agricultural economics and marketing in the tropics. Intermediate Tropical Agricultural Series. Longman Group Ltd, London.

- Acland J.D. (1971) East African crops: an introduction to the production of field and plantation crops in Kenya, Tanzania and Uganda. Longman Group UK Limited, Essex

- Agwanda C Kadere T.T., Musabe R. and Flood J. (Undated): Raising incomes of smallholder coconut producers in Kenya through more efficient value chain management. CABI Africa, Kenya.

- Bedford Biofuels (2010) Environmental and social impact assessment study report: the proposed establishment of jatropha plantations in Garsen Division, Tana Delta District, Kenya. Bedford Biofuels.

- Business Daily (2011) Hasten fuel blending plan. Online newspaper article. Available at: http://www.businessdailyafrica.com. Accessed on January 2011.

- C3P (2011) Crops Crises Control Project Website. Available at: http://c3project.iita.org/KenyaCMD.aspx. Accessed on February 2011.

- CIA (2011) Country statistics for Kenya. Available at: https://www.cia.gov/library/publications/the-world-factbook/fields/2012.html. Accessed on January 2011.

- EPZA (2005a) Kenya sugar industry 2005. Export Processing Zones Authority, Kenya.

- EPZA (2005) Vegetable oil industry in Kenya 2005. Export Processing Zones Authority, Kenya.

- ERC (2009) Draft Bio-diesel Licensing Regulations, 2009. Energy Regulatory Commission, Kenya.

- FAO (2007) Sustainable Bioenergy: A Framework for Decision Makers. FAO, Rome.

- GOK (2010) The Energy (Petroleum Pricing) Regulations 2010. Government of Kenya.

- GOK (2004) Sessional Paper No. 4 Energy. Government of Kenya.

- GTZ (2009a) Jatropha: a reality check. GTZ, Germany.

- GTZ (2009b) International Fuel Prices 2009, 6th Edition. GTZ, Germany.

- IDRC (1998) Oil crops; sunflower, linseed and sesame: proceedings of the Fourth Oil Crop Network workshop held at Njoro, Kenya, 25-29 January 1998. IDRC, Canada.

- IEA (2009) World Energy Outlook 2009, OECD/IEA, Paris.

- IEA (2010a) Sustainable production of second generation biofuels. OECD/IEA, Paris.

- IEA (2010b) Bioenergy Annual Report 2009. OECD/IEA, Paris. 
- JSP (2011) Jatropha Support Programme Website http://www.degjsp.com

- KARI (2009) Assessment of costs of maize production, marketing and processing in Kenya: a maize meal value chain analysis. KARI, Kenya.

- KESREF (2009) Kenya Sugar Research Foundation. Strategic Plan 2009-2014.

- KESREF (2011) Author's interview with KESREF officers.

- KIPPRA (2010) A comprehensive study and analysis on energy consumption patterns in Kenya; A synopsis of the draft final report. KIPPRA, Kenya.

- KIRDI (2011) Author's interview with MOE officers.

- KNBS (2010) Economic survey 2010. Kenya National Bureau of Statistics, Kenya.

- Mgonja M A, Reddy B, Manyas E, Ojulong H (2011) Sweet sorghum for bioethanol: advances in research and development: challenges \& opportunities. A presentation during the Sweet Sorghum Conference on $28^{\text {th }}$ February 2011. ICRSIAT, Nairobi.

- Mitchell D. (2011) Biofuels in Africa; opportunities, prospects and challenges. The International Bank for Reconstruction and Development. The World Bank 1818 H Street, NW.

- MOA (2010) Economic Review of Agriculture 2010. Ministry of Agriculture, Kenya.

- MOA (2009) Economic Review of Agriculture 2009. Ministry of Agriculture, Kenya.

- MOA (2005) Farm Management Handbook of Kenya Vol. II. Part A, West Kenya. Ministry of Agriculture, Kenya.

- MOE (2009) Draft Bioethanol Strategy 2009-2012. MOE, Kenya.

- MOE (2010) Draft National Biofuel Policy Session Paper 2010. Ministry on Energy, Kenya.

- MOE (2011) Author's interview with MOE officers.

- MOE/GTZ (2008) A roadmap to biofuels in Kenya; opportunities and obstacles. Endelevu Energy, Kenya.

- Muok B.O. Kirui S., Theuri D. and Wakhungu J. W. (2008): Policies and Regulations Affecting Biofuel Development in Kenya. PISCES, Kenya.

- Muok, B.O, Nyabenge M., Ouma B. O., Esilaba A. O., Nandokha T. and Owuor B. (2010): Environmental Suitability and Agro-environmental Zoning of Kenya for Biofuel Production. PISCES, Kenya

- Ndegwa G. (2010) Wood fuel value chain analysis in Kenya and Rwanda; economic analysis of the market-oriented woodfuel sector. Unpublished Masters thesis. Cologne University of Applied Sciences, Germany.

- Nyamai D.O. and Omuodo L.O. (2007) Jatropha curcas. The untapped potential in Eastern and Central Africa. Production and utilization manual. Trees on Farm Network (TOFNET). 
- O' Neil I.C. and Kamau C.K. (1990) Sorghum improvement in Kenya. In: Proceedings of the $7^{\text {th }}$ EARSAM Regional workshop on sorghum and millet improvement. Oxford: Nairobi, Kenya.

- Okoko N. E. K., Mahasi M. J., Kidula N., Ojowi M. and Makini F. (2008) Participatory sunflower production, technology dissemination and value addition in southwest Kenya. African Journal of Agricultural Research Vol. 3 (6), pp. 396-399, June 2008. Available online at http://www.academicjournals.org/AJAR. Accessed on February 2011.

- Okuthe I. K. (2008) Socio-economic determinants of adoption of improved sorghum varieties and technologies among smallholder farmers in western Kenya. Egerton University, Kenya

- PISCES (2009) Sustainable biofuel crops and access in developing countries. ACTS, Nairobi.

- Practical Action (2009): International Symposium: Rethinking Biomass Energy in SubSaharan Africa, Bonn, on 25 August 2009. Practical Action, UK.

- Rao S.S., Ashok-Kumar A., Wani S. P., Venkateswarlu B., Kamal A., Bluemmel M., Ramana-Reddy Y., Palaniswamy A. R. and Reddy B.V.S (2008): Cultural practices for maximizing stalk and bioethanol yields. International Crops Research Institute for the Semi-Arid Tropics, Patancheru, India.

- Scarlat N., Dallemand J.-F. (2011) Recent developments of biofuels/bioenergy sustainability certification: a global overview. Energy Policy.

- Scott A. (2009) Large-scale biofuel programmes in Africa - who benefits? Paper presented at the VENRO and German NGO Forum on Environment and Development.

- Van Eijck J. (2007) Transition towards Jatropha biofuels in Tanzania? An analysis with Strategic Niche Management. African Studies Centre, African Studies Collection, vol. 3, Leiden, the Netherlands.

- Wiskerke W. (2008) Towards a sustainable biomass energy supply for rural households in semi-arid Shinyanga, Tanzania; A cost/benefit analysis. MSc thesis, Utrecht University. 


\section{APPENDICES}

Table A1: Gross margin calculation for one hectare of sorghum in Kenya

\begin{tabular}{|c|c|c|c|c|}
\hline Item & Units & Quantity & $\begin{array}{l}\text { Unit price } \\
\text { (Ksh) }\end{array}$ & $\begin{array}{l}\text { Total (per } \\
\text { ha) }\end{array}$ \\
\hline \multicolumn{5}{|l|}{ Yields: } \\
\hline Seeds & $\mathrm{kg}$ & 2000 & 17 & 34000 \\
\hline Stalks & tonnes & 35 & 1000 & 35000 \\
\hline Total income $(A)$ & & & & 69000 \\
\hline \multicolumn{5}{|l|}{ Variable costs } \\
\hline \multicolumn{5}{|l|}{ Inputs } \\
\hline Seeds & $\mathrm{kg}$ & 10 & 20 & 200 \\
\hline Equipment (hoes, machete) & no. & & & 2000 \\
\hline DAP fertilizer for planting & $50 \mathrm{~kg}$ bags & 2 & 2500 & 5000 \\
\hline CAN fertilizer for topdressing & $50 \mathrm{~kg}$ bags & 2 & 2500 & 5000 \\
\hline Pesticides (Thiodan) & $\mathrm{L}$ & 2 & 500 & 1000 \\
\hline Pesticides (Furadine) & $\mathrm{kg}$ & 2 & 1200 & 2400 \\
\hline Sub-total & & & & 15600 \\
\hline \multicolumn{5}{|l|}{ Labour (Ksh/ha) } \\
\hline Land preparation & man days & 15 & 200 & 3000 \\
\hline Furrowing & man days & 10 & 200 & 2000 \\
\hline Planting & man days & 10 & 200 & 2000 \\
\hline Fertilization & man days & 5 & 200 & 1000 \\
\hline Pest control & man days & 5 & 200 & 1000 \\
\hline Weeding & man days & 15 & 200 & 3000 \\
\hline Harvesting & man days & 10 & 200 & 2000 \\
\hline Threshing, winnowing and packing & man days & 10 & 200 & 2000 \\
\hline Sub-total & & & & 16000 \\
\hline Total variable costs $(\mathrm{B})$ & & & & 31600 \\
\hline Gross margin (per season) & & & & 37400 \\
\hline Gross margin (per annum- 2 seasons) & & & & 76800 \\
\hline NPV (at $14 \%$ at interest rate) & & & & 67584 \\
\hline
\end{tabular}

Spacing: $30 \mathrm{~cm}$ between farrows 
Table A2: Gross margin calculation for 1 ha of castor (Ricinus communis) in Kenya

\begin{tabular}{|c|c|c|c|c|c|c|c|c|c|c|}
\hline Years & 1 & 2 & 3 & 4 & 5 & 6 & 7 & 8 & 9 & 10 \\
\hline Yields (kg/ha) & 1002.5 & 1002.5 & 1002.5 & 1002.5 & 1002.5 & 1002.5 & 1002.5 & 1002.5 & 1002.5 & 1002. \\
\hline Income@Ksh 20/kg (A) & 20050 & 20050 & 20050 & 20050 & 20050 & 20050 & 20050 & 20050 & 20050 & 200 \\
\hline
\end{tabular}

Income@ Ksh 20/kg (A)

Variable costs

\section{Inputs}

Seeds $(10 \mathrm{~kg} @ \mathrm{Ksh} 200 / \mathrm{kg})$

Equipment (shovels, hoes, sprayer, buckets, etc). $10 \%$

replacement cost of worn-out equipment every other year

Manure $(0.5 \mathrm{~kg} / \mathrm{tree} @ \mathrm{Ksh} 1.1 / \mathrm{kg})$

Pest/diseases control (0.25 g/tree @ Ksh 2000/kg)

DAP fertilizer for planting $(2,50 \mathrm{~kg}$ bag @ 3500$)$

\section{Sub-total}

\section{Labour (Ksh/ha)}

Land preparation (20 man days @ Ksh 200)

Planting (10 man days (year 1 and 6)@KSh200)

Fertilization (5 man days/year@ Ksh 200)

Pest/diseases control (5 man days/year @ Ksh 200)

Weeding (20 man days/year @ Ksh 200)

Harvesting (15 man days/year@ Ksh 200)

Sub-total

Total variable costs (B)

Cash flows (A-B)

Discount rate $14 \%$

Discounted cash flows

NPV

IRR

NPV annual equivalent

Spacing: $1 \mathrm{mx} 1.5 \mathrm{~m}$ Population $=6666$ 
Table A3: Gross margin calculation for 1 ha of jatropha in Kenya

\begin{tabular}{|c|c|c|c|c|c|c|c|c|c|c|}
\hline Years & 1 & 2 & 3 & 4 & 5 & 6 & 7 & 8 & 9 & 10 \\
\hline Yields (kg/ha) & 8 & 138 & 189 & 309 & 526 & 646 & 766 & 905 & 905 & 905 \\
\hline Income @ Ksh 15/kg (A) & 120 & 2070 & 2835 & 4635 & 7890 & 9690 & 11490 & 13575 & 13575 & 13575 \\
\hline \multicolumn{11}{|l|}{ Variable costs } \\
\hline \multicolumn{11}{|l|}{ Inputs $(\mathrm{Ksh} / \mathrm{Ha})$} \\
\hline Seeds (3 kg @Ksh 775/kg) & 2325 & 0 & 0 & 0 & 0 & 0 & 0 & 0 & 0 & 0 \\
\hline $\begin{array}{l}\text { Equipment (Shovels, hoes, sprayer, buckets, etc). } 10 \% \text { replacement } \\
\text { cost of worn-out equipment every other year }\end{array}$ & 2500 & 250 & 250 & 250 & 250 & 250 & 250 & 250 & 250 & 250 \\
\hline Manure (1.2kg/tree @Ksh 1.1/kg) & 2112 & 2112 & 2112 & 2112 & 2112 & 2112 & 2112 & 2112 & 2112 & 2112 \\
\hline Pest/disease control (3kg furadine @ Ksh 1200/kg) & 3600 & 3600 & 3600 & 3600 & 3600 & 3600 & 3600 & 3600 & 3600 & 3600 \\
\hline Sub-total & 10537 & 5962 & 5962 & 5962 & 5962 & 5962 & 5962 & 5962 & 5962 & 5962 \\
\hline \multicolumn{11}{|l|}{ Labour (Ksh/ha) } \\
\hline Land preparation(ox)@ KSh 3000/ha & 3000 & 0 & 0 & 0 & 0 & 0 & 0 & 0 & 0 & 0 \\
\hline Planting (6 man days @KSh250) & 1500 & 0 & 0 & 0 & 0 & 1500 & 0 & 0 & 0 & 0 \\
\hline Fertilization (5 man days/year @ Ksh 250) & 1250 & 1250 & 1250 & 1250 & 1250 & 1250 & 1250 & 1250 & 1250 & 1250 \\
\hline Pest/diseases control (4 man days/year @ Ksh 250) & 1000 & 1000 & 1000 & 1000 & 1000 & 1000 & 1000 & 1000 & 1000 & 1000 \\
\hline Weeding (12 man days/year @ Ksh 250) & 3000 & 3000 & 3000 & 3000 & 3000 & 3000 & 3000 & 3000 & 3000 & 3000 \\
\hline Harvesting@ KSh250/man day & 500 & 1000 & 1500 & 2000 & 2500 & 2500 & 2500 & 2500 & 2500 & 2500 \\
\hline Sub-total & 10250 & 6250 & 6750 & 7250 & 7750 & 9250 & 7750 & 7750 & 7750 & 7750 \\
\hline Total variable costs (B) & 20787 & 12212 & 12712 & 13212 & 13712 & 15212 & 13712 & 13712 & 13712 & 13712 \\
\hline Cash flows (A-B) & -20667 & -10142 & -9877 & -8577 & -5822 & -5522 & -2222 & -137 & -137 & -137 \\
\hline Discount rate $14 \%$ & 0.88 & 0.77 & 0.67 & 0.59 & 0.52 & 0.46 & 0.40 & 0.35 & 0.31 & 0.27 \\
\hline Discounted cash flows & -18128.9 & -7803.94 & -6666.69 & -5078.27 & -3023.76 & $-2515,75$ & -887.994 & -48.0266 & -42.1286 & -36.9549 \\
\hline NPV & \multicolumn{10}{|l|}{-44232.5} \\
\hline IRR & \multicolumn{10}{|l|}{ N/A } \\
\hline NPV annual equivalent & \multicolumn{10}{|l|}{-4423.25} \\
\hline
\end{tabular}


Table A4: Gross margin calculation for 1 ha of croton in Kenya

\begin{tabular}{|c|c|c|c|c|c|c|c|c|c|c|}
\hline Years & 1 & 2 & 3 & 4 & 5 & 6 & 7 & 8 & 9 & 10 \\
\hline Yields (kg/ha) & 0 & 600 & 1200 & 2400 & 4000 & 5600 & 7200 & 8400 & 9200 & 10000 \\
\hline Income @ Ksh 6/kg (A) & 0 & 3600 & 7200 & 14400 & 24000 & 33600 & 43200 & 50400 & 55200 & 60000 \\
\hline \multicolumn{11}{|l|}{ Variable costs } \\
\hline \multicolumn{11}{|l|}{ Inputs $(\mathrm{KSh} / \mathrm{Ha})$} \\
\hline Seedlings (500@Ksh 25/seedling) & 12500 & 0 & 0 & 0 & 0 & 0 & 0 & 0 & 0 & 0 \\
\hline $\begin{array}{l}\text { Equipment (Shovels, hoes, sprayer, buckets, etc). } 10 \% \text { replacement cost of worn-out } \\
\text { equipment every other year }\end{array}$ & 4900 & 490 & 490 & 490 & 490 & 490 & 490 & 490 & 490 & 490 \\
\hline Manure (2.5kg/tree @ Ksh 1.1/kg) & 1100 & 1100 & 1100 & 1100 & 1100 & 1100 & 1100 & 1100 & 1100 & 1100 \\
\hline Pest/disease control (3 g/tree @Ksh 2000/kg) & 2400 & 2400 & 2400 & 2400 & 2400 & 2400 & 2400 & 2400 & 2400 & 2400 \\
\hline DAP fertilizer for planting $(2,50 \mathrm{~kg}$ bag @ 3500) & 7000 & 0 & 0 & 0 & 0 & 0 & 0 & 0 & 0 & \\
\hline Sub-total & 27900 & 3990 & 3990 & 3990 & 3990 & 3990 & 3990 & 3990 & 3990 & 3990 \\
\hline \multicolumn{11}{|l|}{ Labour (Ksh/ha) } \\
\hline Land preparation (20 man days @ KSh 200) & 4000 & 0 & 0 & 0 & 0 & 0 & 0 & 0 & 0 & 0 \\
\hline Planting (20 man days @ KSh200) & 4000 & 0 & 0 & 0 & 0 & 0 & 0 & 0 & 0 & 0 \\
\hline Fertilization (5 man days/year@ Ksh 200) & 1000 & 1000 & 1000 & 1000 & 1000 & 1000 & 1000 & 1000 & 1000 & 1000 \\
\hline Pest/diseases control (twice, 5 man days/year @ Ksh 200) & 2000 & 2000 & 2000 & 2000 & 2000 & 2000 & 2000 & 2000 & 2000 & 2000 \\
\hline Pruning (12 man days @ KSh 200) & 2400 & 2400 & 2400 & 2400 & 0 & 0 & 0 & 0 & 0 & 0 \\
\hline Weeding (20 man days/year @ Ksh 200 first four years) & 4000 & 4000 & 4000 & 4000 & 0 & 0 & 0 & 0 & 0 & 0 \\
\hline Harvesting@ Ksh 200/man day & 0 & 1000 & 2000 & 3000 & 6000 & 8000 & 10000 & 12000 & 14000 & 16000 \\
\hline Sub-total & 17400 & 10400 & 11400 & 12400 & 9000 & 11000 & 13000 & 15000 & 17000 & 19000 \\
\hline Total variable costs (B) & 45300 & 14390 & 15390 & 16390 & 12990 & 14990 & 16990 & 18990 & 20990 & 22990 \\
\hline Cash flows (A-B) & -45300 & -10790 & -8190 & -1990 & 11010 & 18610 & 26210 & 31410 & 34210 & 37010 \\
\hline Discount rate $14 \%$ & 0.88 & 0.77 & 0.67 & 0.59 & 0.52 & 0.46 & 0.40 & 0.35 & 0.31 & 0.27 \\
\hline Discounted cash flows & -39736.8 & -8302.55 & -5528.02 & $-1178,24$ & 5718.249 & 8478.466 & 10474.49 & 11011.06 & 10519.85 & 9983.22 \\
\hline NPV & 1439.68 & & & & & & & & & \\
\hline IRR & $0 \%$ & & & & & & & & & \\
\hline NPV annual equivalent & 143.97 & & & & & & & & & \\
\hline
\end{tabular}


Table A5: Gross margin calculation for one hectare of cotton in Kenya

\begin{tabular}{|c|c|c|c|c|}
\hline Item & Units & Quantity & \begin{tabular}{|l|} 
Unit price \\
(Ksh)
\end{tabular} & Total (per ha) \\
\hline Yields & $\mathrm{kg}$ & 572 & 32 & 18304 \\
\hline \multicolumn{5}{|l|}{ Variable costs } \\
\hline \multicolumn{5}{|l|}{ Inputs } \\
\hline Cotton Seed & $\mathrm{kg}$ & 5 & 50 & 250 \\
\hline Equipment (hoes, machete) & & & & 2000 \\
\hline DAP fertilizer for planting & $50 \mathrm{~kg}$ bags & 2 & 2500 & 5000 \\
\hline CAN fertilizer for topdressing & $50 \mathrm{~kg}$ bags & 2 & 2500 & 5000 \\
\hline Pesticides & & & & 10000 \\
\hline Sub-total & & & & 22250 \\
\hline \multicolumn{5}{|l|}{ Labour (Ksh/ha) } \\
\hline Land preparation & man days & 15 & 200 & 3000 \\
\hline Planting & man days & 10 & 200 & 2000 \\
\hline Fertilization & man days & 5 & 200 & 1000 \\
\hline Pest control & man days & 10 & 200 & 2000 \\
\hline Weeding & man days & 15 & 200 & 3000 \\
\hline Harvesting & man days & 10 & 200 & 2000 \\
\hline Sub-total & & & & 13000 \\
\hline Total variable costs (B) & & & & 35250 \\
\hline Gross margin & & & & -16946 \\
\hline$N P V$ (at 14\%) & & & & -14912.48 \\
\hline
\end{tabular}

Spacing: $5 \mathrm{mx} 5 \mathrm{~m}$. Population $=400$
Table A6: Gross margin calculation for one hectare of maize in Kenya

\begin{tabular}{|c|c|c|c|c|}
\hline Item & Units & Quantity & Unit price (Ksh) & Total (per ha) \\
\hline \begin{tabular}{|l} 
Yields (A) \\
\end{tabular} & $90 \mathrm{~kg}$ bags & 17 & 1800 & 30600 \\
\hline \multicolumn{5}{|l|}{ Variable costs } \\
\hline \multicolumn{5}{|l|}{\begin{tabular}{|l|} 
Inputs \\
\end{tabular}} \\
\hline Seeds & $\mathrm{kg}$ & 40 & 20 & 800 \\
\hline Equipment ( hoes, machete ) & no. & & & 2000 \\
\hline DAP fertilizer for planting & $50 \mathrm{~kg}$ bags & 2 & 2500 & 5000 \\
\hline CAN fertilizer for topdressing & $50 \mathrm{~kg}$ bags & 2 & 2500 & 5000 \\
\hline \begin{tabular}{|l|} 
Storage dust \\
\end{tabular} & $50 \mathrm{gm}$ bags & 2 & 250 & 500 \\
\hline \begin{tabular}{|l|} 
Sub-total \\
\end{tabular} & & & & 13300 \\
\hline \multicolumn{5}{|l|}{ Labour (Ksh/ha) } \\
\hline Land preparation & man days & 15 & 200 & 3000 \\
\hline \begin{tabular}{|l|} 
Planting \\
\end{tabular} & man days & 10 & 200 & 2000 \\
\hline \begin{tabular}{|l|} 
Fertilization \\
\end{tabular} & man days & 5 & 200 & 1000 \\
\hline \begin{tabular}{|l|} 
Weeding \\
\end{tabular} & $\begin{array}{l}\text { man days } \\
\end{array}$ & 15 & 200 & 3000 \\
\hline Harvesting & man days & 10 & 200 & 2000 \\
\hline Threshing, winnowing and packing & man days & 10 & 200 & 2000 \\
\hline Sub-total & & & & 13000 \\
\hline \begin{tabular}{|l} 
Total variable costs (B) \\
\end{tabular} & & & & 26300 \\
\hline \begin{tabular}{|l} 
Gross margin \\
\end{tabular} & & & & 4300 \\
\hline NPV (at 14\%) & & & & 3784 \\
\hline
\end{tabular}

Spacing: $75 \mathrm{~cm}$ by $30 \mathrm{~cm}$. Population 17,777 
Table A7: Gross margin calculation for one hectare of beans in Kenya

\begin{tabular}{|c|c|c|c|c|}
\hline Item & Units & Quantity & Unit price (Ksh) & Total (per ha) \\
\hline Income (A) & $90 \mathrm{~kg}$ bags & 8 & 4800 & 38400 \\
\hline \multicolumn{5}{|l|}{ Variable costs } \\
\hline \multicolumn{5}{|l|}{ Inputs } \\
\hline Seeds & $\mathrm{kg}$ & 25 & 100 & 2500 \\
\hline Equipment ( hoes, machete ) & no. & & & 2000 \\
\hline DAP fertilizer for planting & $50 \mathrm{~kg}$ bags & 2 & 2500 & 5000 \\
\hline CAN fertilizer for topdressing & $50 \mathrm{~kg}$ bags & 2 & 2500 & 5000 \\
\hline Storage dust & 50 gm bags & 2 & 250 & 500 \\
\hline Sub-total & & & & 15000 \\
\hline \multicolumn{5}{|l|}{ Labour (Ksh/ha) } \\
\hline Land preparation & man days & 15 & 200 & 3000 \\
\hline Planting & man days & 10 & 200 & 2000 \\
\hline Fertilization & man days & 5 & 200 & 1000 \\
\hline Weeding & man days & 15 & 200 & 3000 \\
\hline Harvesting & man days & 10 & 200 & 2000 \\
\hline $\begin{array}{l}\text { Threshing, winnowing and } \\
\text { packing }\end{array}$ & man days & 10 & 200 & 2000 \\
\hline Sub-total & & & & 13000 \\
\hline Total variable costs (B) & & & & 28000 \\
\hline Seasonal Gross margin & & & & 10400 \\
\hline Annual gross margin & & & & 20800 \\
\hline NPV (at 14\%) & & & & 18304 \\
\hline
\end{tabular}

Spacing: $75 \mathrm{~cm}$ by $30 \mathrm{~cm}$. Population: 59,259
Table A8: Gross margin calculation for one hectare of cassava in Kenya

\begin{tabular}{|l|l|l|l|l|}
\hline Item & Units & Quantity & Unit price (Ksh) & Total (per ha) \\
\hline Yields & tonnes & 10 & 8000 & $\mathbf{8 0 0 0 0}$ \\
\hline Variable costs (A) & & & & \\
\hline Inputs & & & & \\
\hline Cuttings & no. & 10000 & 1 & 10000 \\
\hline Equipment ( hoes, machete) & & & & 8000 \\
\hline DAP fertilizer for planting & $50 \mathrm{~kg}$ bags & 2 & 2500 & 5000 \\
\hline CAN for topdressing & $50 \mathrm{~kg}$ bags & 2 & 2500 & 5000 \\
\hline Sub-total & & & & $\mathbf{2 8 0 0 0}$ \\
\hline Labour (Ksh/ha) & & & & \\
\hline Land preparation & man days & 20 & 200 & 4000 \\
\hline Planting & man days & 20 & 200 & 4000 \\
\hline Fertilization & man days & 5 & 200 & 1000 \\
\hline Weeding & man days & 20 & 200 & 4000 \\
\hline Earthing up & man days & 20 & 200 & 4000 \\
\hline Harvesting & man days & 40 & 200 & 8000 \\
\hline Bagging and transport & man days & 20 & 200 & 4000 \\
\hline Sub-total & & & $\mathbf{2 0 2 4 0}$ \\
\hline Total variable costs (B) & & & & $\mathbf{5 7 0 0 0}$ \\
\hline Gross margin & & & & $\mathbf{2 3 0 0 0}$ \\
\hline NPV (at 14\%) & & & & \\
\hline
\end{tabular}


Table A9: Gross margin calculation for one hectare of sunflower in Kenya

\begin{tabular}{|l|l|l|l|l|} 
Item & Units & Quantity & $\begin{array}{l}\text { Unit price } \\
\text { (Ksh) }\end{array}$ & $\begin{array}{l}\text { Total (per } \\
\text { ha) }\end{array}$ \\
\hline Income (A) & $\mathrm{kg}$ & 2000 & 15 & $\mathbf{3 0 0 0 0}$ \\
\hline Variable costs & & & & \\
\hline Inputs & & & & \\
\hline Seeds & $\mathrm{kg}$ & 2 & 170 & 340 \\
\hline Equipment ( hoes, machete) & no. & & & 2000 \\
\hline DAP fertilizer for planting & $50 \mathrm{~kg}$ bags & 2 & 2500 & 5000 \\
\hline CAN fertilizer for topdressing & $50 \mathrm{~kg}$ bags & 2 & 2500 & 5000 \\
\hline Sub-total & & & & $\mathbf{1 2 3 4 0}$ \\
\hline Labour (Ksh/ha) & & & & \\
\hline Land preparation & man days & 15 & 200 & 3000 \\
\hline Planting & man days & 10 & 200 & 2000 \\
\hline Fertilization & man days & 5 & 200 & 1000 \\
\hline Weeding & man days & 15 & 200 & 3000 \\
\hline Bird watching & man days & 30 & 100 & 3000 \\
\hline Harvesting & man days & 10 & 200 & 2000 \\
\hline $\begin{array}{l}\text { Threshing, winnowing and } \\
\text { packing }\end{array}$ & man days & 10 & 200 & 2000 \\
\hline Sub-total & & & & $\mathbf{1 6 0 0 0}$ \\
\hline Total variable costs (B) & & & & $\mathbf{2 8 3 4 0}$ \\
\hline Seasonal Gross margin (A-B) & & & & $\mathbf{1 6 6 0}$ \\
\hline Annual Gross margin & & & & $\mathbf{3 3 2 0}$ \\
\hline NPV (at 14\% interest rate) & & & & \\
\hline
\end{tabular}




\section{WORKING PAPER SERIES 2010/2011}

97. Economic viability of Jatropha curcas L. plantations in Northern Tanzania- assessing farmers' prospects via cost-benefit analysis.

98. Hot spot of emission and confusion: land tenure insecurity, contested policies and competing claims in the central Kalimantan Ex-Mega Rice Project area

99. Agroforestry competences and human resources needs in the Philippines

100. CES/COS/CIS paradigms for compensation and rewards to enhance environmental services

101. Case study approach to region-wide curriculum and teaching materials development in agroforestry education in Southeast Asia

102. Stewardship agreement to reduce emissions from deforestation and degradation (REDD): Lubuk Beringin's Hutan Desa as the first village forest in Indonesia

107. Tree domestication by ICRAF and partners in the Peruvian Amazon: lessons learned and future prospects in the domain of the Amazon Initiative eco-regional program

108. Memorias del Taller Nacional: "Iniciativas para Reducir la Deforestación en la region AndinoAmazónica", 09 de Abril del 2010. Proyecto REALU Peru

109. Percepciones sobre la Equidad y Eficiencia en la cadena de valor de REDD en Perú -Reporte de Talleres en Ucayali, San Martín y Loreto, 2009. Proyecto REALU-Perú.

110. Reducción de emisiones de todos los Usos del Suelo. Reporte del Proyecto REALU Perú Fase 1

111. Programa Alternativas a la Tumba-y-Quema (ASB) en el Perú. Informe Resumen y Síntesis de la Fase II. 2da. versión revisada

112. Estudio de las cadenas de abastecimiento de germoplasma forestal en la amazonía Boliviana

113. Biodiesel in the Amazon

114. Estudio de mercado de semillas forestales en la amazonía Colombiana

115. Estudio de las cadenas de abastecimiento de germoplasma forestal en Ecuador

116. How can systems thinking, social capital and social network analysis help programs achieve impact at scale?

117. Energy policies, forests and local communities in the Ucayali Region, Peruvian Amazon

118. NTFPs as a source of livelihood diversification for local communities in the Batang Toru Orangutan Conservation Program

119. Studi Biodiversitas: Apakah agroforestry mampu mengkonservasi keanekaragaman hayati di DAS Konto?

120. Estimasi Karbon Tersimpan di Lahan-lahan Pertanian di DAS Konto, Jawa Timur

121. Implementasi Kaji Cepat Hidrologi (RHA) di Hulu DAS Brantas, Jawa Timur

122. Kaji Cepat Hidrologi di Daerah Aliran Sungai Krueng Peusangan, NAD, Sumatra

123. A study of rapid hydrological appraisal in the Krueng Peusangan Watershed, NAD, Sumatra

124. An assessment of farm timber value chains in Mt Kenya area, Kenya

125. A comparative financial analysis of current land use systems and implications for the adoption of improved agroforestry in the East Usambaras, Tanzania

126. Agricultural monitoring and evaluation systems

127. Challenges and opportunities for collaborative landscape governance in the East Usambara Mountains, Tanzania

128. Transforming Knowledge to Enhance Integrated Natural Resource Management Research, Development and Advocacy in the Highlands of Eastern Africa

129. Carbon-forestry projects in the Philippines: potential and challenges The Mt Kitanglad Range forest-carbon development

130. Carbon forestry projects in the Philippines: potential and challenges. The ArakanForest Corridor forestcarbon project

131. Carbon-forestry projects in the Philippines: potential and challenges. The Laguna Lake Development Authority's forest-carbon development project

132. Carbon-forestry projects in the Philippines: potential and challenges. The Quirinoforest-carbo development project in Sierra Madre Biodiversity Corridor

133. Carbon-forestry projects in the Philippines: potential and challenges. The Ikalahan Ancestral Domain forest-carbon development

134. The importance of local traditional institutions in the management of natural resources in the highlands of eastern Africa

135. Socio-economic assessment of irrigation pilot projects in Rwanda

136. Performance of three rambutan varieties (Nephelium lappaceum L.) on various nursery media

137. Climate change adaptation and social protection in agroforestry systems: enhancing adaptive capacity and minimizing risk of drought in Zambia and Honduras

138. Does value chain development contribute to rural poverty reduction? Evidence of asset building by smallholder coffee producers in Nicaragua 
The World Agroforestry Centre is an autonomous, non-profit research organization whose vision is a rural transformation in the developing world where smallholder households strategically increase their use of trees in agricultural landscapes to improve their food security, nutrition, income, health, shelter, energy resources and environmental sustainability. The Centre generates science-base knowledge about the diverse role that trees play in agricultural landscapes, and uses its research to advance policies and practices that benefit the poor and the environment.

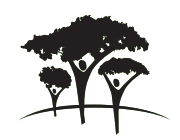

United Nations Avenue, Gigiri - PO Box 30677 - 00100 Nairobi, Kenya

Tel: +254207224000 or via USA +1 6508336645

Fax: +254 207224001 or via USA +16508336646

www.worldagroforestry.org 